\title{
A família Orchidaceae no Parque Municipal de Mucugê, Bahia, Brasil
}

\author{
Cecília Oliveira de Azevedo ${ }^{1,2}$ e Cássio van den Berg ${ }^{1}$
}

Recebido: 20.09.2005; aceito: 20.11.2006

\begin{abstract}
The Orchidaceae of "Parque Municipal de Mucugê", Bahia, Brazil). This study presents a survey of the Orchidaceae occurring in the "Parque Municipal de Mucugê, Mucugê", Bahia, Brazil. It was carried out trough monthly sampling during 12 months. Thirty five species of orchids were recorded in 22 genera, of which 18 species are for the first time reported for Mucugê, eight for the Chapada Diamantina and four for the state of Bahia. The main genera in number of species are Bulbophyllum, Epidendrum, Octomeria and Prescottia. Lectotypes for Acianthera hamosa (Bard. Rodr.) Pridgeon \& M.W. Chase, Cattleya elongata Bard. Rodr., Maxillaria cerifera Bard. Rodr., and Prescottia montana Bard. Rodr. are chosen here. All taxa are described and illustrated, as well as identification keys for species and genera are provided.
\end{abstract}

Key words: campo rupestre, Chapada Diamantina, orchids, taxonomy

RESUMO - (A família Orchidaceae no Parque Municipal de Mucugê, Bahia, Brasil). O levantamento da família Orchidaceae no Parque Municipal de Mucugê foi realizado através de coletas mensais durante o período de um ano. Foram encontradas 35 espécies em 22 gêneros. Destas, 18 são citadas pela primeira vez para o município de Mucugê, oito para a região da Chapada Diamantina e quatro para o Estado da Bahia. Os gêneros Bulbophyllum, Epidendrum, Octomeria e Prescottia foram os mais representativos. Lectótipos foram selecionados para Acianthera hamosa (Bard. Rodr.) Pridgeon \& M.W. Chase, Cattleya elongataBard. Rodr., Maxillaria cerifera Bard. Rodr. e Prescottia montana Bard. Rodr. Todos os táxons são descritos e ilustrados e chaves para identificação dos gêneros e espécies são apresentadas.

Palavras-chave: campo rupestre, Chapada Diamantina, orquídeas, taxonomia

\section{Introdução}

A família Orchidaceae é uma das mais numerosas e especializadas do Reino Vegetal, com cerca de 20.000 espécies distribuídas em aproximadamente 850 gêneros (Atwood 1986, Dressler 1993). Está bem representada no Brasil, com aproximadamente 2.350 espécies distribuídas em 200 gêneros (Pabst \& Dungs 1975, 1977). Na Bahia foram registradas 285 espécies (Pabst \& Dungs 1975, 1977, Harley \& Mayo 1980, Harley \& Simmons 1986, Toscano-de-Brito 1995, 1998, Toscano-de-Brito \& Queiroz 2003).

Estudos recentes têm demonstrado que a melhor estratégia de investigação da dinâmica e distribuição geográfica das espécies dos campos rupestres da Cadeia do Espinhaço é a realização de inventários florísticos detalhados de áreas reduzidas, escolhidas devido à sua alta diversidade e estado de conservação (Harley 1995). Seguindo essa estratégia, inventários têm sido executados em várias áreas da Chapada Diamantina.
A Cadeia do Espinhaço é constituída por dois blocos principais, a porção mineira e a baiana, esta última conhecida como Chapada Diamantina. No seu extremo sul, a Chapada Diamantina divide-se em duas cadeias independentes, a Serra do Rio de Contas e a Serra das Almas, a oeste, e a Serra do Sincorá, a leste (Harley 1995). Inventários florísticos revelaram a presença de 161 espécies de Orchidaceae para a Chapada Diamantina (Harley \& Simmons 1986, Toscano-de-Brito 1995, 1998, Toscano-de-Brito \& Queiroz 2003, van den Berg \& Azevedo 2005).

O Parque Municipal de Mucugê, localiza-se no município de Mucugê, nas imediações do Parque Nacional da Chapada Diamantina, na Serra do Sincorá, a cerca de $4 \mathrm{~km}$ da cidade de Mucugê, entre as coordenadas $12^{\circ} 59^{\prime} 02^{\prime \prime}-13^{\circ} 00^{\prime} 18^{\prime \prime} \mathrm{S}$ e $41^{\circ} 19^{\prime} 40^{\prime \prime}$ $41^{\circ} 21^{\prime} 33^{\prime \prime} \mathrm{W}$, a uma altitude em torno de $1.000 \mathrm{~m}$ acima do nível do mar e área de $4,5 \mathrm{~km}^{2}$. A vegetação predominante na área é o campo rupestre, que é um importante centro de diversidade da flora brasileira, destacando-se por apresentar grande número de

1. Universidade Estadual de Feira de Santana, Departamento de Ciências Biológicas, Laboratório de Sistemática Molecular de Plantas, Rodovia BR 116, km 03, 44031-460 Feira de Santana, BA, Brasil

2. Autor para correspondência: cicaazevedo@gmail.com 
espécies endêmicas (Harley \& Simmons 1986, Harley 1995). Nele a família Orchidaceae apresenta grande importância florística, estando sempre entre as dez famílias de maior riqueza específica (Harley \& Simmons 1986, Giulietti et al. 1987, Stannard 1995, Guedes \& Orge 1998, Pirani et al. 2003, Zappi et al. 2003).

Como forma de contribuir para o conhecimento dessa área, o presente trabalho teve como objetivo inventariar, descrever e ilustrar as espécies da família Orchidaceae do Parque Municipal de Mucugê, apresentar comentários sobre a morfologia, hábito, aspectos fenológicos e distribuição geográfica das várias espécies dessa família presentes na área e elaborar chaves para identificação dos gêneros e espécies.

\section{Material e métodos}

Excursões mensais à área foram realizadas durante o período de junho de 2002 a maio de 2003, visando a coleta de amostras vegetais em toda a área do Parque Municipal de Mucugê (PMM). O material coletado foi desidratado e herborizado de acordo com Mori et al. (1989) e flores conservadas em solução alcoólica (álcool 70\%: água 25\%: glicerina 5\%). As exsicatas foram depositadas no acervo do herbário da Universidade Estadual de Feira de Santana (HUEFS). Coleções depositadas nos herbários ALCB, CEPEC, HRB, HUEFS, K, SPF e $\mathrm{W}$ foram consultadas.

Dados sobre distribuição geográfica e fenologia foram obtidos de informações contidas nas etiquetas das exsicatas examinadas e complementados com observações de campo. Dados sobre a distribuição geral de cada táxon foram obtidos através de consulta à bibliografia especializada, sobretudo Pabst \& Dungs (1975, 1977) e Sprunger et al. (1996). Sinônimos só foram apresentados para casos recentemente mencionados, que não haviam sido citados anteriormente por Pabst \& Dungs $(1975,1977)$, ou nos casos duvidosos que ainda hoje apresentam problemas.

Todas as espécies foram ilustradas (Figuras 1-18).

\section{Resultados e Discussão}

Foram encontradas no Parque Municipal de Mucugê 35 espécies de orquídeas, distribuídas em 22 gêneros, das quais uma é um híbrido natural (Azevedo et al. 2006). Os gêneros com maior representatividade foram Bulbophyllum (3 spp. e 1 nothosp.), Epidendrum (4 spp.), Octomeria (3 spp.) e Prescottia
(3 spp.), enquanto 68\% dos gêneros apresentaram apenas uma espécie.

Algumas espécies de Orchidaceae encontradas no PMM possuem ampla distribuição geográfica, podendo ser encontradas em outros países, e apresentando-se bem distribuídas no Brasil. Das 35 espécies coletadas no PMM, quatro são novos registros para o Estado da Bahia, anteriormente citadas para outras regiões, sobretudo Sul e Sudeste do país. Oito são novos registros para a região da Chapada Diamantina e outras 18 são novos registros para o município de Mucugê. A área apresenta espécies endêmicas da Chapada Diamantina como Encyclia alboxanthina Fowlie, Sophronitis bahiensis (Schltr.) Van den Berg \& M.W.Chase e Thelyschista ghillanyi (Pabst) Garay.

O PMM está incluído na área onde foi realizada a Flórula de Mucugê (Harley \& Simmons 1986), que envolveu partes dos municípios de Andaraí e Mucugê, abrangendo $896 \mathrm{~km}^{2}$. Nela foram encontradas 26 espécies da família Orchidaceae, distribuídas em 13 gêneros. Destas, somente 10 espécies são comuns aos dois levantamentos, enquanto 16 espécies foram encontradas apenas na Flórula e não no PMM. O número de espécies exclusivas da Flórula era esperado, devido ao maior tamanho da área amostrada, porém o fato de o PMM apresentar 26 espécies, que não foram encontradas na Flórula, é bastante significativo. Este caso representa um exemplo claro de como a diferença de objetivo, e conseqüentemente da metodologia e do esforço de amostragem, pode influenciar nos resultados, gerando uma falsa impressão da situação. É importante ressaltar que as Orchidaceae do PMM foram inventariadas através de coletas mensais durante o período de um ano, com foco voltado unicamente para essa família.

As espécies encontradas na área de estudo, descritas por Barbosa-Rodrigues, Cattleya elongata Barb.Rodr., Maxillaria cerifera Barb. Rodr., Pleurothallis hamosa Barb. Rodr. e Prescottia montana Barb.Rodr., foram lectotipificadas, uma vez que os holótipos destas espécies, assim como a quase totalidade da coleção de Barbosa-Rodrigues, foram destruídos durante uma enchente na cidade do Rio de Janeiro (Cribb \& Toscano-de-Brito 1996). Dessa forma, as ilustrações originais de sua Iconographie des orchidées du Brésil, recentemente publicada por Sprunger et al. (1996), constituem o único material original disponível, e por esse motivo foram selecionadas como lectótipos. 
Chave de identificação para os gêneros de Orchidaceae ocorrentes no Parque Municipal de Mucugê

1. Inflorescência lateral, emergindo da base do pseudobulbo ou caule, ou entre as folhas

2. Plantas de crescimento monopodial

Campylocentrum

2. Plantas de crescimento simpodial

3. Pseudobulbo tetra-angulado Bulbophyllum

3. Pseudobulbo ovóide ou fusiformes

4. Sépalas laterais adnadas na base até a metade; polínias 2

Oncidium

4. Sépalas laterais livres na base, polínias 4

5. Pseudobulbos 25-49 mm compr., fusiformes; labelo marcadamente 3-lobado; lobos laterais 8,0-11 mm compr. Cyrtopodium

5. Pseudobulbos 10-15 mm compr., ovóides; labelo obscuramente 3-lobado; lobos laterais inconspícuos $1,5 \mathrm{~mm}$ compr. Maxillaria

1. Inflorescência terminal, emergindo do ápice do pseudobulbo ou caule

6. Pseudobulbos superpostos, alguns emergindo da base e outros do ápice do pseudobulbo anterior Scaphyglottis

6. Pseudobulbos ou caule não superpostos, emergindo apenas do rizoma ou da base do pseudobulbo anterior

7. Labelo livre

8. Labelo tripartido, com a base prolongada em cálcar; antera completamente fundida com o resto da coluna

8. Labelo inteiro a 3-lobado, base do labelo não prolongada em cálcar; antera claramente distinguível do resto da coluna

9. Flores não ressupinadas (labelo superior na antese)

10. Plantas com caule inconspícuo; labelo cuculado, internamente glabro; polínias 4

10. Plantas com caule constituído de pseudobulbos $10-20$ mm compr.; labelo oblongo, internamente coberto por tricomas (porção central); polínias 2

Prescottia

9. Flores ressupinadas (labelo inferior na antese)

11. Pseudobulbo ou caule com folhas apenas no ápice

12. Inflorescência em fascículo

Octomeria

12. Inflorescência não fasciculada

13. Polínias 8 Sophronitis

13. Polínias 2 ou 4

14. Pseudobulbos 2-3-foliados; sépalas laterais livres; polínias 4 Cattleya

14. Caule 1-foliado; sépalas laterais adnadas ao menos na base; polínias 4

15. Plantas 60-170 mm alt.; inflorescência com 5-9-flores; sépalas laterais adnadas da base até no mínimo $2 / 3$ do comprimento

15. Plantas 10-50 mm alt.; inflorescência com 1-2 flores; sépalas

laterais adnadas na base até $1 / 3$ do comprimento
ou caule com folhas ao longo de sua extensão Acianthera

11. Pseudobulbo ou caule com folhas ao longo de sua extensão
16. Folhas $7-12 \mathrm{~cm}$ compr., plicadas, coriáceas; labelo inteiro Anathallis

16. Folhas 1-2 cm compr., não plicadas, membranáceas; labelo distintamente 3-lobado Sobralia Cleistes

7. Labelo coalescente em alguma extensão à coluna

17. Labelo coalescente à porção lateral da coluna

18. Caule inconspícuo; folhas basais em roseta, com nervação paralelinervia; epicálice ausente; flores branco-esverdeadas; labelo 3-lobado, lobos laterais envolvendo a coluna e coalescente na base à sua face lateral Thelyschista 
18. Caule 150-200 cm compr.; folhas ao longo da extensão do caule; folhas com nervação reticulada; epicálice presente; flores lilás, labelo inteiro, coalescente à face lateral da coluna até $1 / 3$ de seu comprimento Epistephium

17. Labelo coalescente à face adaxial da coluna

19. Labelo parcialmente coalescente à base da coluna

20. Pseudobulbo cilíndrico, 1-foliado; folha terete; polínias 8 . Brassavola

20. Pseudobulbo ovóide, 2-4-foliado; folha lanceolada a oblonga; polínias 4

21. Inflorescência 110-130 cm compr. com 8-30 flores ressupinadas Encyclia

21. Inflorescência 40-70 mm compr. com 4-6 flores não ressupinadas Prosthechea

19. Labelo coalescente à toda extensão da coluna Epidendrum

\section{Acianthera (Scheidw.) C.A.Luer}

Chave de identificação para as espécies de Acianthera ocorrentes no Parque Municipal de Mucugê

1. Caule compresso no ápice; folha genuflexa, ovada, ca. 2 vezes longas que largas, verde a arroxeada; flores vináceas, sépalas laterais adnadas da base até $2 / 3$ do comprimento A. hamosa

1. Caule cilíndrico no ápice; folha ereta, lanceolada, ca. 9-10 vezes mais longa que larga, verdeamarela; flores amarelo-alaranjadas, sépalas laterais adnadas da base ao ápice formando uma navícula A. ochreata subsp. ochreata

Acianthera hamosa (Barb. Rodr.) Pridgeon \& M.W. Chase, Lindleyana 16(4): 243. 2001. Pleurothallis hamosa Barb. Rodr., Gen. spec. Orchid. 2: 31, t. 774. 1882. TIPO: BRASIL, Barbosa-Rodrigues s.n. (perdido). Lectótipo: ilustração original preparada por João Barbosa Rodrigues, t. 774, que consta de sua Iconographie des orchidées du Brésil, depositada na biblioteca do Jardim Botânico do Rio de Janeiro, reproduzida por Sprunger et al. (1996), sob o numero t. 177B do volume 3 , aqui designado

Figuras 1a-c, 16a

Erva rupícola. Rizoma 5-10 mm compr. entre pseudobulbos. Caule 30-120 × 1,5-2 mm, 1-foliado, ereto, cilíndrico, compresso no ápice, verde a arroxeado. Folha 35-60 × 15-30 mm, séssil, genuflexa, ovada, verde a arroxeada, coriácea a carnosa, ápice apiculado, base cordada. Inflorescência em racemo terminal, adpressa à folha; pedúnculo 4,5-7 mm compr.; brácteas do pedúnculo 1,5-2 × 1-1,5 mm, ovadas, membranáceas, ápice apiculado, base amplectiva; raque 13-15 mm compr., 5-8-flora; brácteas florais 1,5-2 × 1,5-2 mm, ovadas, membranáceas, ápice apiculado, base amplectiva. Flores ressupinadas; pedicelo, incluindo o ovário, 2,5-3,0 mm compr.; sépalas vináceas, carnosas, papilosas, ápice agudo, a dorsal 4-4,5 × 1,5 mm, ereta, adnada na base com as sépalas laterais, lanceolada, as laterais 4,5-5 × 1-1,5 mm, eretas, adnadas da base até $2 / 3$ do comprimento formando uma navícula; pétalas 2-2,5 ×0,5-1 mm, eretas, lanceoladas, vináceas, membranáceas, ápice agudo, margem serreada; labelo preso ao pé da coluna, ereto, 3-lobado, obovado, vináceo, membranáceo, papiloso, lobos laterais inconspícuos, erguidos, oblongos, ápice obtuso, margem serrilhada, lobo terminal 2,5-3 × 1-1,5 mm, ereto, obovado, ápice obtuso; coluna $2 \times 0,5 \mathrm{~mm}$, esverdeada; prolongada na base em pé de $0,5 \mathrm{~mm}$ compr., polínias 2. Fruto cápsula, $10-13 \times 5,5-6,5 \mathrm{~mm}$.

Material examinado: 18-IX-2002, C. Azevedo \& $R$. Oliveira 150 (HUEFS).

Restrita ao Brasil, foi descrita originalmente a partir de material proveniente de Minas Gerais (Barbosa Rodrigues 1882), foi citada também para o Rio de Janeiro e São Paulo. Na Bahia, é conhecida para a Chapada Diamantina nos municípios de Rio de Contas (Toscano-de-Brito 1995), Lençóis (Toscano-de-Brito 1998) e Palmeiras (Toscano-deBrito 1998, Conceição \& Giulietti 2002). Esta é a primeira citação para o município de Mucugê, onde é encontrada sobre as rochas em áreas de campo rupestre e em matas de grotão. O comprimento do caule, a textura das folhas e sua coloração variam de acordo com o hábitat. Plantas mais expostas ao sol apresentam caules mais curtos, folhas mais carnosas e coloração arroxeada, enquanto as que crescem em áreas mais sombreadas, nas matas de 
grotão, apresentam caules mais longos, folhas mais finas e coloração esverdeada. Floresce entre agosto e setembro.

Acianthera hamosa é reconhecida por seu caule compresso no ápice, sua folha genuflexa, inflorescência adpressa à folha, pela coloração verde a arroxeada de seus caules e folhas, por suas flores vináceas e por apresentar pétalas e lobos laterais do labelo de margem serrilhada.

Acianthera hamosa e Acianthera prolifera (Herb. ex Lindl.) Pridgeon \& M.W. Chase apresentam a mesma distribuição geográfica (Pabst \& Dungs 1975), apesar da última ter sido descrita originalmente para o Rio de Janeiro (Lindley 1830). Assemelham-se muito em seu hábito, apresentando caule compresso no ápice, folha genuflexa e inflorescência adpressa à folha, embora Acianthera prolifera diferencie-se por ser epífita, produzir constantemente brotos nas axilas das folhas e por apresentar labelo inteiro. Pabst (1966) diferenciou as duas espécies pelo tamanho maior (8-10 cm compr.) e forma aconchavada das folhas de Acianthera prolifera, enquanto Acianthera hamosa apresenta folhas menores (5-6 cm compr.), só um pouco côncavas.

Acianthera ochreata (Lindl.) Pridgeon \& M.W. Chase subsp. ochreata, Lindleyana 16(4): 245. 2001. Pleurothallis ochreata Lindl., Bot. Reg. 21 (n.s. 8): sub t. 1797. 1836.

Figuras 1d-f, 16b

Erva rupícola. Rizoma ca. $5 \mathrm{~mm}$ compr. entre pseudobulbos. Caule 60-70 × 2-2,5 mm, 1-foliado, ereto, cilíndrico, amarelo-alaranjado a esverdeado. Folha 90-100 × $10 \mathrm{~mm}$, séssil, ereta, lanceolada, amarelo-alaranjada a esverdeada, carnosa, ápice agudo. Inflorescência em racemo terminal, ereto; pedúnculo 30-45 mm compr., amarelado; brácteas do pedúnculo 3-4 × 3,5-4 mm, ovadas, membranáceas, ápice apiculado, base amplectiva; raque $20-35 \mathrm{~mm}$ compr., 5-9-flora; brácteas florais 2,5-3 × 4-4,5 mm, ovadas, membranáceas, ápice apiculado, base amplectiva. Flores ressupinadas; pedicelo, incluindo o ovário, 2,5-3 mm compr.; sépalas eretas, amareloalaranjadas, carnosas, ápice agudo, a dorsal 5,5-6 $\times$ $1-1,5 \mathrm{~mm}$, lanceolada, as laterais 5,5-6 $\times 1-1,5 \mathrm{~mm}$, adnadas da base até o ápice formando uma navícula; pétalas 2-2,5 × 0,5-1 mm, eretas, lineares, amareloalaranjadas, carnosas, ápice apiculado, margem serrilhada; labelo preso ao pé de coluna, ereto, 3-lobado, oblongo, amarelo-alaranjado, carnoso, calosidade em forma de duas quilhas erguidas na porção mediana do lobo terminal, lobos laterais 1,0-1,5 $\times$ 0,5-1 mm, erguidos, oblongos, ápice obtuso; lobo terminal 1-1,5 × $1 \mathrm{~mm}$, ereto, oblongo, ápice obtuso; coluna 2,5-3 $\times 0,5-1 \mathrm{~mm}$, alada, prolongada na base em pé $0,5-1 \mathrm{~mm}$ compr., polínias 2 . Fruto cápsula $14-14,5 \times 5-6 \mathrm{~mm}$.

Materiais examinados: 11-VI-2002, C. Azevedo \& J. Oliveira 139 (HUEFS); Unidade de Manejo Sustentável, 4-I-1997, UMS 124 (HRB); idem, 1-XI-1996, UMS 345 (HRB).

Material adicional examinado: BRASIL. BAHIA: Mucugê, 2 km N de Mucugê, 20-I-1997, M.M. Arbo et al. 7571 (CEPEC); by rio Cumbuca, about $3 \mathrm{~km}$ $\mathrm{N}$ of Mucugê on the road to Andaraí, 15-II-1977, R.M. Harley et al. 18712 (CEPEC, K); about $2 \mathrm{~km}$ along Andaraí road, 25-I-1980, R.M. Harley et al. 20589 (CEPEC, K); $10 \mathrm{~km} \mathrm{~N}$ da cidade na rod. para Andaraí, 27-I-2000, J.G. Jardim et al. 2550 (CEPEC).

Esta espécie foi descrita originalmente para a Serra do Monte Santo, Bahia (Lindley 1836a). Restrita ao Brasil, Pabst \& Dungs (1975) registraram sua ocorrência para Pernambuco e Bahia. Segundo Borba \& Semir (2001), Acianthera ochreata é uma espécie com ampla distribuição no Nordeste do Brasil, especialmente no Estado da Bahia, mas também é encontrada em Pernambuco e na Paraíba. Na Bahia é conhecida para a Serra do Curral Feio, Morro do Chapéu, Serra do Sincorá, Serra do Rio de Contas, Serra das Almas (Harley \& Mayo 1980), Catolés (Toscano-de-Brito \& Queiroz 2003), e para os municípios de Mucugê/Andaraí (Harley \& Simmons 1986), Rio de Contas (Toscano-de-Brito 1995), Lençóis (Toscano-de-Brito 1998) e Palmeiras (Toscano-deBrito 1998; Conceição \& Giulietti 2002). Acianthera ochreata subsp. ochreata é abundante nos campos rupestres da Chapada Diamantina, e muito comum na área do PMM, onde cresce em grandes populações, diretamente sobre as rochas a pleno sol. Sua coloração e textura podem variar de acordo com o habitat. Plantas mais expostas ao sol apresentam folhas mais carnosas e coloração amarelo-alaranjada, enquanto as que crescem em áreas sombreadas apresentam folhas menos carnosas e coloração esverdeada. Floresce entre novembro e fevereiro. Segundo Borba \& Semir (2001), suas flores possuem néctar na base do labelo, cheiram a queijo estragado e são polinizadas por dípteros. 


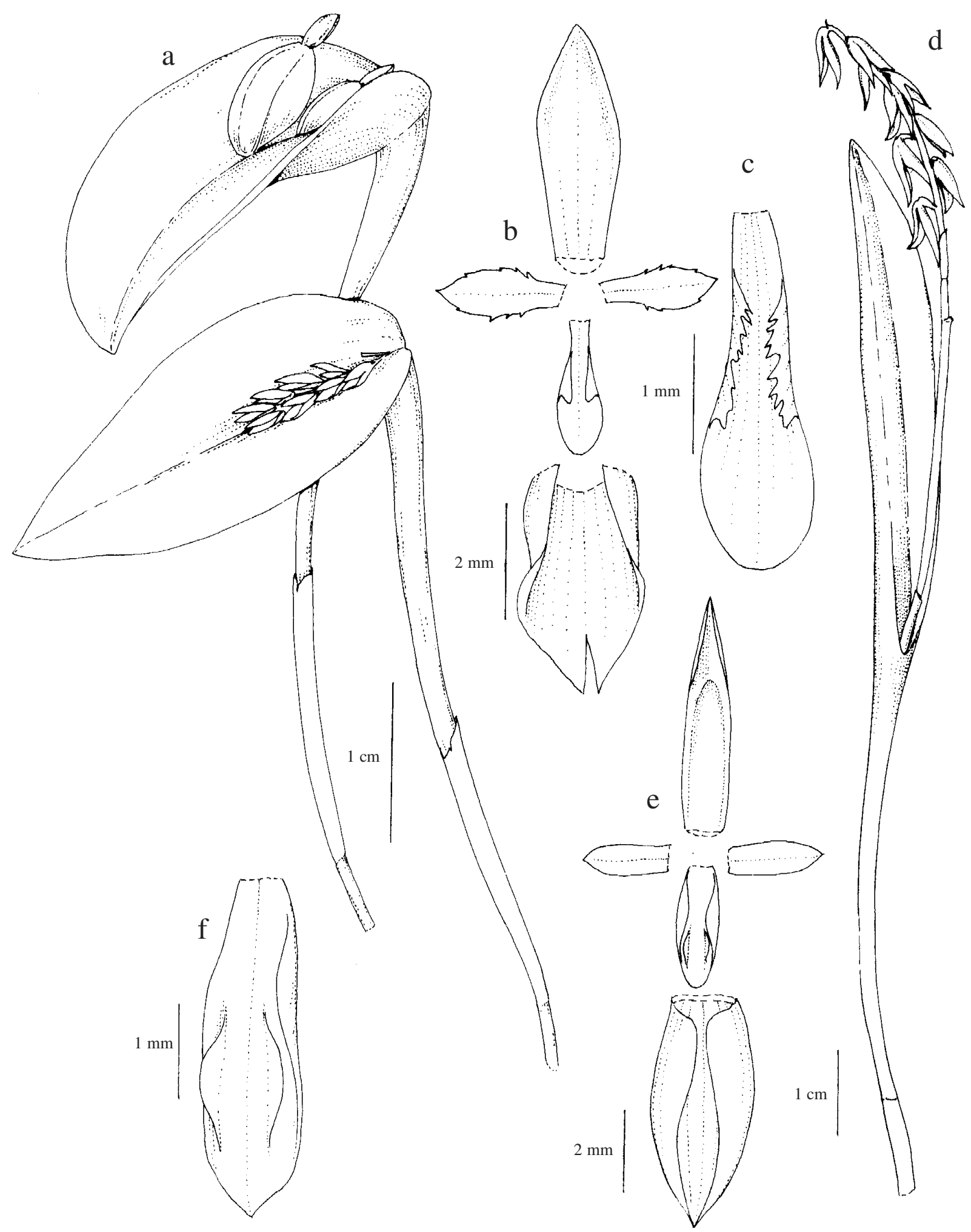

Figura 1a-c. Acianthera hamosa. a. Hábito. b. Diagrama floral. c. Detalhe do labelo (C. Azevedo \& R. Oliveira 150). d-f Acianthera ochreata subsp. ochreata. d. Hábito. e. Diagrama floral. f. Detalhe do labelo (C. Azevedo \& J. Oliveira 139). 
O próprio Pabst (1966), após examinar o holótipo de Acianthera ochreata, concluiu que a espécie descrita por ele para a Chapada Diamantina, entre Lençóis e Palmeiras, com o nome de Pleurothallis bahiensis Pabst (Pabst 1956), era somente uma forma mais robusta daquela. Recentemente, Acianthera ochreata subsp. cylindrifolia (Borba \& Semir) Borba, foi descrita baseada em diferenças morfológicas de caracteres vegetativos, diferenças químicas e de localização geográfica. Acianthera ochreata subsp. cylindrifolia diferencia-se vegetativamente da subespécie tipo por apresentar folhas cilíndricas sulcadas e ocorre apenas na Cadeia do Espinhaço em Minas Gerais. Acianthera ochreata subsp. ochreata apresenta folhas carnosas nitidamente conduplicadas (Borba et al. 2002, Borba 2003).

Acianthera ochreata subsp. ochreata é reconhecida por suas folhas carnosas de coloração amarelo-alaranjada, e por suas flores com sépalas laterais adnadas da base até o ápice, formando uma navícula. Assemelha-se a Acianthera teres (Lindl.) Borba, por apresentar caracteres florais bastante similares, mas difere em caracteres vegetativos e na distribuição geográfica, sendo que esta ocorre, principalmente, em Minas Gerais, e algumas populações no Rio de Janeiro e Espírito Santo (Borba et al. 2002). Ao contrário de Acianthera teres, Acianthera fabiobarrosii (Borba \& Semir) F. Barros $\&$ F. Pinheiro apresenta grande similaridade vegetativa com A. ochreata subsp. ochreata, sendo que esta ocorre apenas na região centro-norte da Cadeia do Espinhaço, em Minas Gerais (Borba et al. 2000).

Anathallis Barb. Rodr.

Chave de identificação para as espécies de Anathallis ocorrentes no Parque Municipal de Mucugê

1. Inflorescência com uma única flor em antese; flores vináceas, sépalas e pétalas de margem ciliada A. microphyta

1. Inflorescência com duas flores, flores amareladas; sépalas e pétalas de margem não ciliada A. montipelladensis

Anathallis microphyta (Barb. Rodr.) C.O. Azevedo \& Van den Berg, Kew Bull. 60(1): 137. 2005. Pleurothallis microphyta (Barb. Rodr.) Cogn., Fl. bras. 3(4): 484. 1895.

Figuras 2a-c, 16c, d

Erva rupícola. Rizoma inconspícuo. Caule 20-40 ×
0,5-1 mm, 1-foliado, ereto, cilíndrico, marrom. Folha 5-10 × 3-4 mm, séssil, ereta, lanceolada a orbicular, verde, coriácea, ápice retuso, base atenuada. Inflorescência em racemo terminal, ereto; pedúnculo 3,5-6 mm compr., marrom; brácteas do pedúnculo inconspícuas; raque 3-8 mm compr., 1 flor; brácteas florais 1,5-2 $\times 1$-1,5 mm, orbiculares, membranáceas, ápice agudo, base amplectiva. Flores ressupinadas; pedicelo, incluindo o ovário, 1-1,5 mm compr.; sépalas lanceoladas, membranáceas, ápice agudo, margem ciliada, a dorsal 3-3,5 $\times 1-1,5 \mathrm{~mm}$, ereta, adnada na base às sépalas laterais, vinácea, as laterais $3 \times 1 \mathrm{~mm}$, reflexas, adnadas na base, até $1 / 3$ do comprimento, vináceas com lista branca na base; pétalas $3 \times 0-1 \mathrm{~mm}$, eretas, lineares, vináceas, membranáceas, ápice agudo, margem ciliada; labelo articulado com o pé da coluna de $1 \mathrm{~mm}$ compr., ereto, 3-lobado, orbicularoblongo, vináceo, carnoso, calo convexo na porção basal do labelo, lobos laterais inconspícuos, eretos, semi-orbiculares, ápice obtuso, ciliado, lobo terminal $2 \times 1 \mathrm{~mm}$, orbicular-oblongo, ápice obtuso; coluna $2 \times 0,5 \mathrm{~mm}$, branca com manchas vináceas, polínias 2. Fruto cápsula $4-5 \times 2-3 \mathrm{~mm}$.

Material examinado: 18-IX-2002, C. Azevedo \& R. Oliveira 152 (HUEFS).

Descrita originalmente de espécime originário da Serra do Mar (Barbosa-Rodrigues 1882), esta espécie é citada para a Argentina, e para o Brasil, nos Estados do Rio de Janeiro e Rio Grande do Sul (Pabst \& Dungs 1975, Sprunger et al. 1996), sendo registrada pela primeira vez para o Estado da Bahia por Azevedo \& van den Berg (2005). Anathallis microphyta é rara na área do PMM, encontrada somente em áreas sombreadas e úmidas das matas de grotão, crescendo sobre rochas cobertas por musgos, o que dificulta sua localização. Floresce entre maio e setembro.

Anathallis microphyta é reconhecida por seu pequeno porte e suas flores vináceas. Assemelha-se muito a Anathallis corticicola (Schltr. ex Hoehne) Pridgeon \& M.W. Chase, diferindo por apresentar pétalas de margem inteira, lisa, enquanto A. microphyta possui sépalas e pétalas de margem ciliada. O próprio Hoehne (1936) quando descreveu Pleurothallis corticicola reconheceu que esta era tão parecida com Pleurothallis microphyta que ele não podia afirmar com absoluta certeza se esta era uma espécie realmente ou se era somente uma variedade da mesma. Semelhante também a Anathallis paranaensis (Schltr.) Pridgeon \& M.W. 
Chase. Segundo Hoehne (1930) Anathallis microphyta aparta-se desta última e de outras da secção Lepanthiformes, por ter bainhas caulinares glabras com óstio inteiro e flores fasciculadas e sésseis sobre os caules secundários.

Anathallis montipelladensis (Hoehne) F. Barros, Bradea 8(43): 295. 2002. Pleurothallis montipelladensis Hoehne, Arch. Inst. Biol. (São Paulo) 2: 36, pl. 6, fig. 1. 1929.

Figuras 2d, e, 16e, f

Erva rupícola. Rizoma 0,5-1 mm compr. entre pseudobulbos. Caule (1,5-)3-6×0,5-1,5 mm, 1-foliado, ereto, cilíndrico, verde, coberto por bainhas. Folha 6-16 × 2,5-4 mm, séssil, ereta, lanceolada a quase orbicular, verde, carnosa, ápice acuminado. Inflorescência em racemo terminal, ereto; pedúnculo 9-29 mm compr., amarelado; brácteas do pedúnculo inconspícuas; raque 3,5-10 mm compr., 2-flora; brácteas florais inconspícuas. Flores ressupinadas; pedicelo, incluindo o ovário, 0,5-1,5 mm compr.; sépalas eretas, lanceoladas, amareladas, membranáceas, ápice obtuso, a dorsal 3-3,5 × $1-1,5 \mathrm{~mm}$, adnada na base às sépalas laterais, as laterais 3-3,5 × 0,5-1 mm, adnadas na base; pétalas 2,5-3 $\times$ 0,5-1 mm, eretas, lineares, amareladas, membranáceas, ápice obtuso, margem serrilhada; labelo articulado com o pé da coluna, ereto, 3-lobado, oblongo, amarelado, membranáceo, lobos laterais inconspícuos, erguidos, semi-orbiculares, ápice obtuso, margem ciliada, lobo terminal 1-1,5 $\times$ 0,5-1 mm, ereto, oblongo, ápice arredondado; coluna $1,5 \times 0,5 \mathrm{~mm}$, amarelada, alada, polínias 2 . Fruto cápsula 4-5 × 2-3 mm.

Materiais examinados: 13-VII-2002, C. Azevedo 142 (HUEFS); 14-VII-2002, C. Azevedo \& J. Oliveira 146 (HUEFS); Unidade de Manejo Sustentável, 6-XI-1996, UMS 343 (HRB).

De distribuição restrita ao Brasil, foi citada para Bahia, São Paulo, Minas Gerais e Mato Grosso (Pabst \& Dungs 1975). Na Chapada Diamantina, foi registrada para os municípios de Rio de Contas (Toscano-de-Brito 1995) e Mucugê (Stradmann 1998). Cresce em paredões rochosos no campo rupestre. Foi observada florida nos meses de abril, julho, agosto e novembro.

Anathallis montipelladensis é facilmente reconhecida pelo seu pequeno porte, $10-20 \mathrm{~mm}$ alt., e sua inflorescência com duas flores amareladas.
Brassavola R. Br.

Brassavola tuberculata Hook., Bot. Mag. 56: t. 2878. 1829.

Figuras 4a-c, $16 \mathrm{~g}$

Erva rupícola. Rizoma 5-10 mm compr. entre pseudobulbos. Caule 60-110 $\times 4 \mathrm{~mm}, 1$-foliado, pendente, cilíndrico, marrom, coberto por bainha. Folha $220 \times$ $5 \mathrm{~mm}$, séssil, pendente, cilíndrica, verde, carnosa, ápice agudo. Inflorescência em racemo terminal, pendente; pedúnculo 10-20 mm compr., verde; brácteas do pedúnculo 3-4 × 4-5 mm, ovadas a orbiculares, paleáceas, ápice agudo, base amplectiva; raque 10-20 mm compr., 3-flora; brácteas florais 3-5 × 2-3 mm, ovadas, paleáceas, ápice agudo. Flores ressupinadas; pedicelo, incluindo o ovário, 40-55 mm compr.; sépalas patentes, lanceoladas, cremeamareladas, membranáceas, ápice agudo, a dorsal 30-38 $\times 4-5 \mathrm{~mm}$, as laterais 30-35 × 5-6 mm; pétalas $30-36 \times 3,0-4,0 \mathrm{~mm}$, patentes, lanceoladas, cremeamareladas, membranáceas, ápice agudo, labelo 30-35 × 15-20 mm, coalescente à base da coluna, ereto, inteiro, ovado, branco com centro amarelo, membranáceo, ápice cuspidado, margem ligeiramente revoluta; coluna $10 \times$ $3 \mathrm{~mm}$, branca, alada, polínias 8 .

Material examinado: 26-XI-2002, C. Azevedo \& R. Oliveira 165 (HUEFS).

Espécie conhecida para a Bolívia e Brasil (Sprunger 1991), onde foi citada para os Estados de Sergipe, Rio de Janeiro, Paraná, Santa Catarina, Rio Grande do Sul e Minas Gerais (Pabst \& Dungs 1975), neste último, para a Serra do Cipó (Barros 1987). Na Bahia, foi citada para Monte Santo (Harley \& Mayo 1980), sendo aqui registrada pela primeira vez para a Chapada Diamantina. É rara no Parque, sendo encontrada crescendo sob paredões rochosos apenas em matas de grotão. Floresce em novembro.

Brassavola tuberculata é caracterizada por seu hábito pendente, folha cilíndricas e flores com sépalas e pétalas creme-amareladas e labelo branco com centro amarelo. Withner (1998) considerou Brassavola fragrans Barb. Rodr., Brassavola perrinii Lindl. e $B$. tuberculata espécies diferentes, apesar de afirmar que $B$. perrinii, B. fragrans e Brassavola flagellaris Barb. Rodr. são parte de um complexo de espécies proximamente relacionadas, que diferem apenas em sua localização geográfica. Aqui, preferiu-se seguir Pabst \& Dungs (1975) e Sprunger (1991) que consideram Brassavola fragrans, Brassavola gibbiana Hort. ex Nichols. e B. perrinii sinônimos de B. tuberculata. 


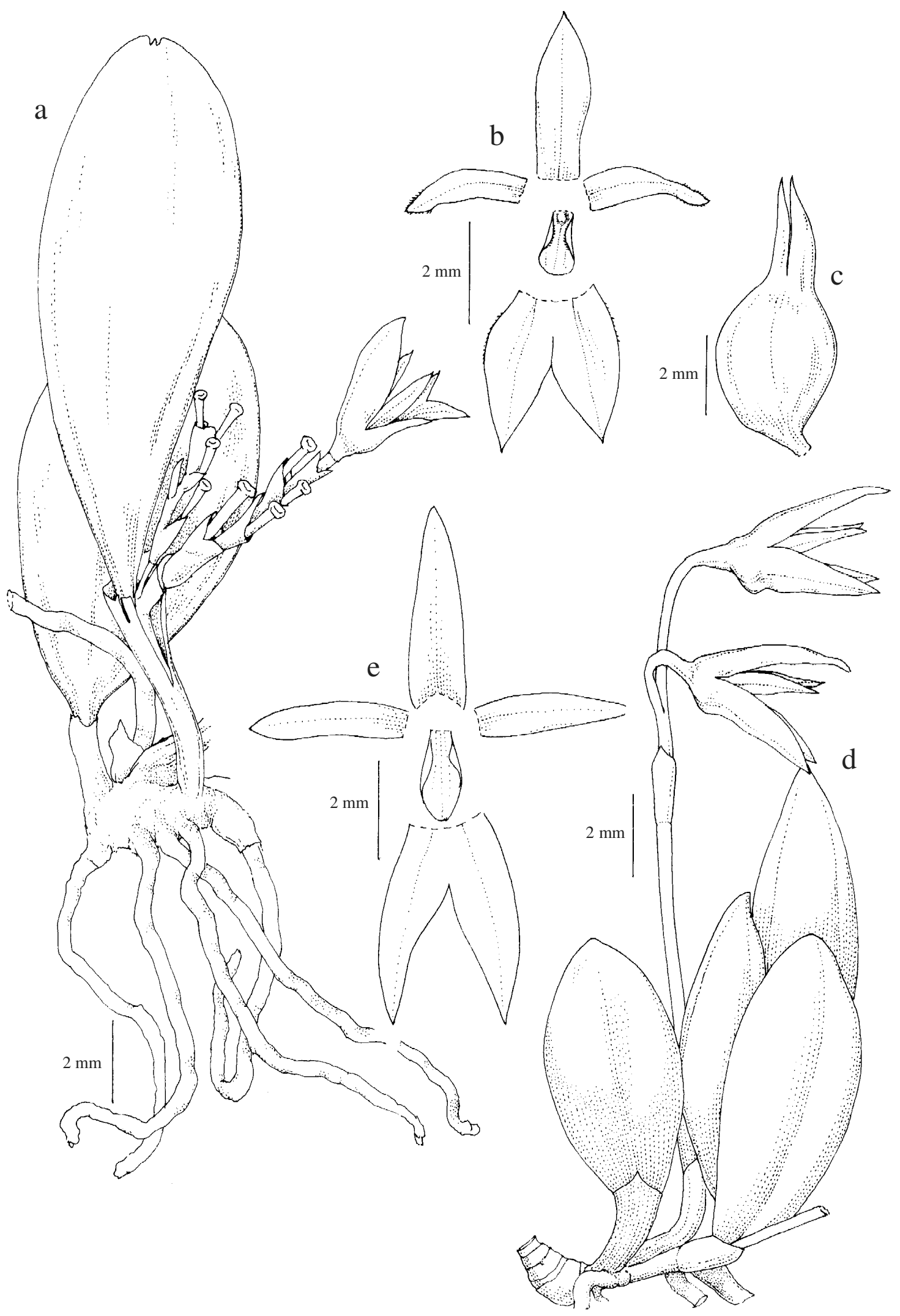

Figura 2a-c. Anathallis microphyta. a. Hábito. b. Diagrama floral. c. Fruto (C. Azevedo \& R. Oliveira 152). d-e. Anathallis montipelladensis. d. Hábito. e. Diagrama floral (C. Azevedo \& J. Oliveira 142). 


\section{Bulbophyllum Thou.}

Chave de identificação de Bulbophyllum ocorrentes no Parque Municipal de Mucugê

1. Inflorescência de pedúnculo ereto e raque genuflexa, pétalas lineares B. weddellii

1. Inflorescência de pedúnculo ereto e raque pendente, pétalas semi-orbiculares, ovadas a triangulares

2. Pétalas muito reduzidas, ca. 0,5 mm compr., semi-orbiculares; pé da coluna ca. $4 \mathrm{~mm}$ compr. B. cribbianum

2. Pétalas 2-5 mm compr., ovadas a triangulares; pé da coluna 1,5-2 mm compr.

3. Sépalas ovadas, base não falcada; pétalas ovadas, de ápice obtuso e margem ciliada; labelo púrpuro com ápice branco

B. involutum

3. Sépalas triangulares, base ligeiramente falcada; pétalas triangulares, de ápice agudo e margem não ciliada; labelo vináceo com manchas e pontuações creme-amareladas com relances metálicos

B. $\times$ cipoense

Bulbophyllum cribbianum Toscano, Kew Bull. 47(4): 774. 1992.

Bulbophyllum micropetalum Barb. Rodr., Gen. spec. Orchid. 2: 121. 1882, non Lindl. (1862).

Figura 3c-e

Erva rupícola. Rizoma 5-10 mm compr. entre pseudobulbos. Pseudobulbos 10-15 × 5-8 mm, 1-foliados, eretos, ovóide-tetrágonos, amarelados. Folha 25-55 × 6-10 mm, séssil, ereto-patente, elípticooblonga a oblonga, verde, coriácea, ápice apiculado. Inflorescência em racemo lateral; pedúnculo 70-120 mm compr., ereto, verde; brácteas do pedúnculo 10-15 × 2-3 mm, lanceoladas, paleáceas, ápice agudo, base amplectiva; raque $25-30 \mathrm{~mm}$ compr., pendente, 2-3-flora concomitantemente em antese; brácteas florais 5-6 × 3-4 mm, ovadas, membranáceas, ápice agudo, base amplectiva. Flores ressupinadas; pedicelo, incluindo o ovário, 2-2,5 mm compr.; sépalas eretas, amarelo-esverdeadas com veios púrpuros, membranáceas, a dorsal 5-6 $\times 5-6 \mathrm{~mm}$, ovada a orbicular, ápice obtuso, as laterais 6-7 $\times$ 5-6 mm, coalescidas lateralmente ao pé da coluna, triangulares a ovadas, ápice obtuso; pétalas $0,5 \times$ $1 \mathrm{~mm}$, eretas, semi-orbiculares, róseas a amareladas com veios púrpuros, membranáceas, ápice obtuso; labelo 5-6 ×3,5-4 mm, articulado com o pé da coluna, ereto, inteiro, oblongo, magenta com margem vinho, membranáceo, ápice obtuso; coluna $2,5 \times 2 \mathrm{~mm}$, esbranquiçada, prolongada na base em pé de $4 \mathrm{~mm}$ compr., polínias 4 . Fruto cápsula 5-7 ×4 mm, amareloesverdeado.

Material examinado: 26-XI-2002, C. Azevedo \& R. Oliveira 167 (HUEFS).
Material adicional examinado: BRASIL. BAHIA: Mucugê, Gerais do Guiné, 17-XI-2001, E.L. Borba 2127 (HUEFS).

Esta espécie foi descrita originalmente para o Rio de Janeiro (Barbosa-Rodrigues 1882), tendo distribuição restrita ao Brasil, foi citada também para o Estado do Espírito Santo (Pabst \& Dungs 1975, Sprunger et al. 1996). Na Bahia, ocorre no município de Rio de Contas (Toscano-de-Brito 1995, Ribeiro et al. 2005) e Mucugê (Ribeiro et al. 2005). Rara na área do Parque, esta espécie foi encontrada crescendo em paredões rochosos de matas de grotão. Floresce em novembro.

Bulbophyllum cribbianum é facilmente reconhecida por suas pétalas muito pequenas, semiorbiculares e pelo longo pé da coluna. Toscano de Brito (1995) comenta que Bulbophyllum cribbianum parece ser rara em herbários brasileiros, pois o espécime citado para Rio de Contas foi a terceira coleção por ele examinada.

Bulbophyllum involutum Borba, Semir \& F. Barros, Novon 8(3): 225. 1998

Figuras 3f, g, 16j

Erva rupícola. Rizoma 10-25 mm compr. entre pseudobulbos. Pseudobulbos 20-30 × 15-20 mm, 1-foliados, eretos, ovóide-tetrágonos, amarelados. Folha 50-80 × 15-25 mm, séssil, sub-ereta, elípticooblonga a oblonga, verde, coriácea, ápice apiculado. Inflorescência em racemo lateral; pedúnculo $24-50 \mathrm{~cm}$ compr., ereto, vináceo; brácteas do pedúnculo 10-18 × 5-7 mm, oblongas a orbiculares, paleáceas, ápice apiculado, base amplectiva; raque (7-)23-28 cm 
compr., pendente, 1-2-flora concomitantemente em antese; brácteas florais 5-7,5 × 2,5-4 mm, triangulares a ovadas, paleáceas, ápice agudo. Flores ressupinadas; pedicelo, incluindo o ovário, 6-6,5 mm compr.; sépalas ovadas, creme com manchas e pontuações purpúreas cobrindo quase completamente a superfície, membranáceas, ápice agudo, a dorsal 8-9 ×3,5-4 mm, recurvada, as laterais 8,0-8,5 × 3,5-4,0 mm, reflexas; pétalas 2-2,5 × 1-1,5 mm, patentes, ovadas, creme com manchas e pontuações purpúreas, membranáceas, ápice obtuso, margem ciliada; labelo articulado com o pé da coluna, ereto, 3-lobado, orbicular, púrpura com ápice branco, carnoso, calo convexo, piloso, lobos laterais 1-1,5 × 0,5-1 mm, eretos, auriculares, ápice obtuso, ciliado, lobo terminal 2-2,5 × 1,5-2 mm, orbicular, ápice obtuso, ciliado; coluna 2,5 ×1,5 mm, esbranquiçada, provida de dois longos braços voltados para frente e dois menores para baixo, prolongada na base em pé de 1,5-2 mm compr., polínias 4. Fruto cápsula, 10-11,5 ×9-10 mm, verde.

Material examinado: 17-IX-2002, C. Azevedo \& J. Oliveira 149 (HUEFS).

Material adicional examinado: BRASIL. BAHIA: Mucugê, margem estrada Mucugê-Cascavel, 20-VII-1981, N.L. Menezes et al. CFCR 1477 (K, SPF).

Endêmica da Cadeia do Espinhaço, esta espécie foi descrita originalmente para Minas Gerais, sendo encontrada também nos campos rupestres da Chapada Diamantina da Bahia (Borba et al. 1998). Em Minas Gerais foi citada para a Serra de Grão-Mogol (Barros \& Pinheiro 2004). No Estado da Bahia, foi citada para os municípios de Abaíra, Jacobina, Mucugê e Rio de Contas (Ribeiro et al. 2005), foi citada também para Rio de Contas (Harley \& Mayo 1980, Toscano-deBrito 1995) e Mucugê (Harley \& Simmons 1986), como Bulbophyllum ipanemense Hoehne. O espécime deste último levantamento, CFCR 1477, foi mais tarde designado como parátipo de Bulbophyllum involutum (Borba et al. 1998). Cresce diretamente sobre as rochas em áreas abertas de campo rupestre, dividindo o mesmo hábitat com Bulbophyllum weddellii (Lindl.) Rchb. f. Floresce em setembro.

Bulbophyllum involutum é reconhecido no campo pela coloração púrpura de suas flores, brácteas, pedúnculo e raque, sempre com uma única flor em antese, diferentemente de Bulbophyllum warmingianum Cogn. e Bulbophyllum ipanemense que têm inflorescências verdes ou amareloesverdeadas, e três a cinco flores simultaneamente em antese. Essas características auxiliam no reconhecimento de Bulbophyllum involutum em material de herbário, uma vez que a coloração do pedúnculo, brácteas e sépalas não se perde totalmente. As pétalas ovadas com ápice obtuso são muito peculiares em comparação com as das outras duas espécies, que são triangulares com ápice agudo (Borba et al. 1998). Sua polinização ocorre pela ação de correntes de vento que movimentam o labelo e pressionam o polinizador contra a coluna da flor (Borba et al. 1998).

Bulbophyllum weddellii (Lindl.) Rchb. f., Ann. Bot. Syst. 6: 251. 1861.

Figuras 3h, i, 16k

Erva rupícola. Rizoma ca. $10 \mathrm{~mm}$ compr. entre pseudobulbos. Pseudobulbos 20-25 × 10-15 mm, 1-foliados, eretos, ovóide-tetrágonos, amarelados, cobertos por bainhas. Folha 40-50 × 15-20 mm, séssil, semi-ereta, elíptico-oblonga a oblonga, verde, coriácea, ápice apiculado. Inflorescência em racemo lateral; pedúnculo 15-20 cm compr., ereto, verde; brácteas do pedúnculo 10-15 × 5-6 mm, orbiculares, ápice agudo, base amplectiva; raque $5-10 \mathrm{~cm}$ compr., genuflexa, 6-20-flora; brácteas florais 7-9,5 ×2-3 mm, ovadas. Flores ressupinadas, pedicelo, incluindo o ovário, 4-5 mm compr.; sépalas oblongo-lanceoladas, creme com manchas e pontuações purpúreas na base, membranáceas, a dorsal 10-15,5 × 2,5-3 mm, recurvada, creme com manchas e pontuações purpúreas na base, membranácea, ápice caudado, as laterais 10-15,5 × 2,5-3 mm, reflexas, ápice agudo, base falcada; pétalas 3-4,5 × 0,5-1 mm, patentes, lineares, creme com manchas e pontuações purpúreas, membranáceas, ápice agudo, margem ciliada; labelo articulado com o pé da coluna, ereto, 3-lobado, lanceolado, creme com manchas e pontuações purpúreas, carnoso, calo convexo, piloso, lobos laterais 1-1,5 × 0,5-1 mm, eretos, auriculares, ápice obtuso, ciliado, lobo terminal 8-12,5 × 2-4 mm, lanceolado, ápice agudo; coluna 3-3,5 × 1,5-2 mm, branca com manchas purpúreas, provido de dois longos braços voltados para frente e dois menores para baixo, prolongada na base em pé de 2-2,5 mm compr., polínias 2 .

Materiais examinados: 12-VI-2002, C. Azevedo \& O. Oliveira 140 (HUEFS); 13-IV-2003, C. Azevedo 188 (HUEFS).

Material adicional examinado: BRASIL. BAHIA: Mucugê, 6-VII-1998, C. Azevedo 88 (HRB). 
Esta espécie foi descrita, originalmente, a partir de material proveniente de Minas Gerais (Lindley 1852); neste estado foi citada para a Serra do Cipó (Barros 1987). De distribuição restrita ao Brasil, é conhecida também para o Estado do Rio de Janeiro (Pabst \& Dungs 1975) e para a Bahia, nos municípios de Rio de Contas (Toscano-de-Brito 1995, Ribeiro et al. 2005) e Mucugê (Ribeiro et al. 2005). A polinização ocorre como em Bulbophyllum involutum (Borba et al. 1998). Floresce entre abril e julho.

Bulbophyllum weddellii é facilmente reconhecido pela inflorescência genuflexa na raque, pela coloração das flores creme com manchas e pontuações purpúreas, além da forma de seus segmentos florais, que apresentam sépalas laterais de base falcada e pétalas lineares.

Bulbophyllum $\times$ cipoense Borba \& Semir, Lindleyana 13: 113.1998.

Figuras 3a-b, 16h, i

Erva rupícola. Rizoma 15-20 mm compr. entre pseudobulbos. Pseudobulbos 22-25 × 12-15 mm, 1-foliados, eretos, ovóide-tetrágonos, amarelados. Folha 80-95 × 15-18 mm, séssil, semi-ereta, elípticooblonga, verde, coriácea, ápice acuminado. Inflorescência em racemo lateral; pedúnculo $50-55 \mathrm{~cm}$ compr., ereto, vináceo; brácteas do pedúnculo 10-14 × 5-7 mm, orbiculares, paleáceas, ápice acuminado, base amplectiva; raque 30-35 cm compr., pendente, 3-4flora concomitantemente em antese; brácteas florais 5-9 × 2-3 mm, triangulares a ovadas, membranáceas, ápice agudo. Flores ressupinadas, pedicelo, incluindo o ovário, $4 \mathrm{~mm}$ compr.; sépalas triangulares, cremearroxeadas com manchas e pontuações purpúreas na base, membranáceas, ápice agudo, a dorsal 10-15 × 3-4 mm, ereta, as laterais 10-15 × 3-4 mm, reflexas, base ligeiramente falcada; pétalas 4-5 × 1-2 mm, patentes, triangulares, cremes com manchas e pontuações purpúreas, membranáceas, ápice agudo; labelo articulado com o pé da coluna, ereto, 3-lobado, obovado, vináceo com manchas e pontuações cremeamareladas com relances metálicos, carnoso, calo convexo, piloso, lobos laterais 2-2,5 × $1 \mathrm{~mm}$, eretos, auriculares, ápice obtuso, ciliado, lobo terminal 5-6 $\times$ 3-4 mm, oblongo, ápice obtuso, ciliado; coluna $2 \times$ $1 \mathrm{~mm}$, creme-amarelada, provida de dois longos braços cruzados voltados para frente e dois menores para baixo, prolongada na base em pé de $2 \mathrm{~mm}$ compr., polínias 4 . Fruto cápsula 10-12 × 6-9 mm, verde com nuances vináceas.
Material examinado: 18-III-2003, C. Azevedo \& E. Oliveira 182 (HUEFS).

Recentemente, Bulbophyllum xcipoense, um híbrido natural entre Bulbophyllum weddellii e Bulbophyllum involutum, foi descrito para a Cadeia do Espinhaço, Minas Gerais (Borba \& Semir 1998). $\mathrm{Na}$ área do PMM, os parentais de Bulbophyllum xcipoense estão presentes, ocorrendo muitas vezes sobre a mesma rocha. Espécimes encontrados no PMM apresentam caracteres que sugerem que o mesmo evento possa ter ocorrido nesta área.

Borba \& Semir (1998), através de estudos de biologia floral e fenologia, concluíram que as espécies parentais são simpátricas, possuem eventos fenológicos sincronizados, caracterizados por um período de floração longo, compartilham os mesmos polinizadores e são intercompatíveis, o que pode levar à formação de híbridos naturais. Borba \& Semir (1998), quando descreveram Bulbophyllum xcipoense, ressaltaram que o híbrido atrai os mesmos polinizadores dos parentais, o que pode causar introgressão. Evento que parece estar acontecendo no PMM, onde os espécimens encontrados apresentam caracteres intermediários entre os parentais e entre si, como o espécime $C$. Azevedo \& J. Oliveira 177 (HUEFS) (figura 16h), que apesar de semelhante ao descrito por Borba \& Semir (1998), apresenta algumas diferenças na coloração, tamanho e forma de seus segmentos florais. Bulbophyllum xcipoense apresenta sépalas e pétalas ovallanceoladas, sépalas ligeiramente falcadas, com manchas e pontuações purpúreas apenas na base e labelo purpúreo com terço distal e margens laterais brancas com manchas purpúreas, e o indivíduo aqui tratado possui sépalas e pétalas ovadas, pétala de margem não ciliada, sépalas não falcadas com manchas e pontuações purpúreas em praticamente todo seu comprimento e labelo sem o terço distal e as margens laterais brancas.

\section{Campylocentrum Benth.}

Campylocentrum micranthum (Lindl.) Rolfe, Orchid Rev. 11(128): 245. 1903.

Figuras 4d-h, 161

Erva epífita. Caule 6-12 cm compr., ereto, cilíndrico, verde, coberto pelas bainhas das folhas. Folhas 2-3,5 × 0,5-1 cm, dísticas, sésseis, patentes, lanceoladas, verdes, coriáceas, ápice retuso, articulada com a bainha. Inflorescência em racemo lateral; raque 


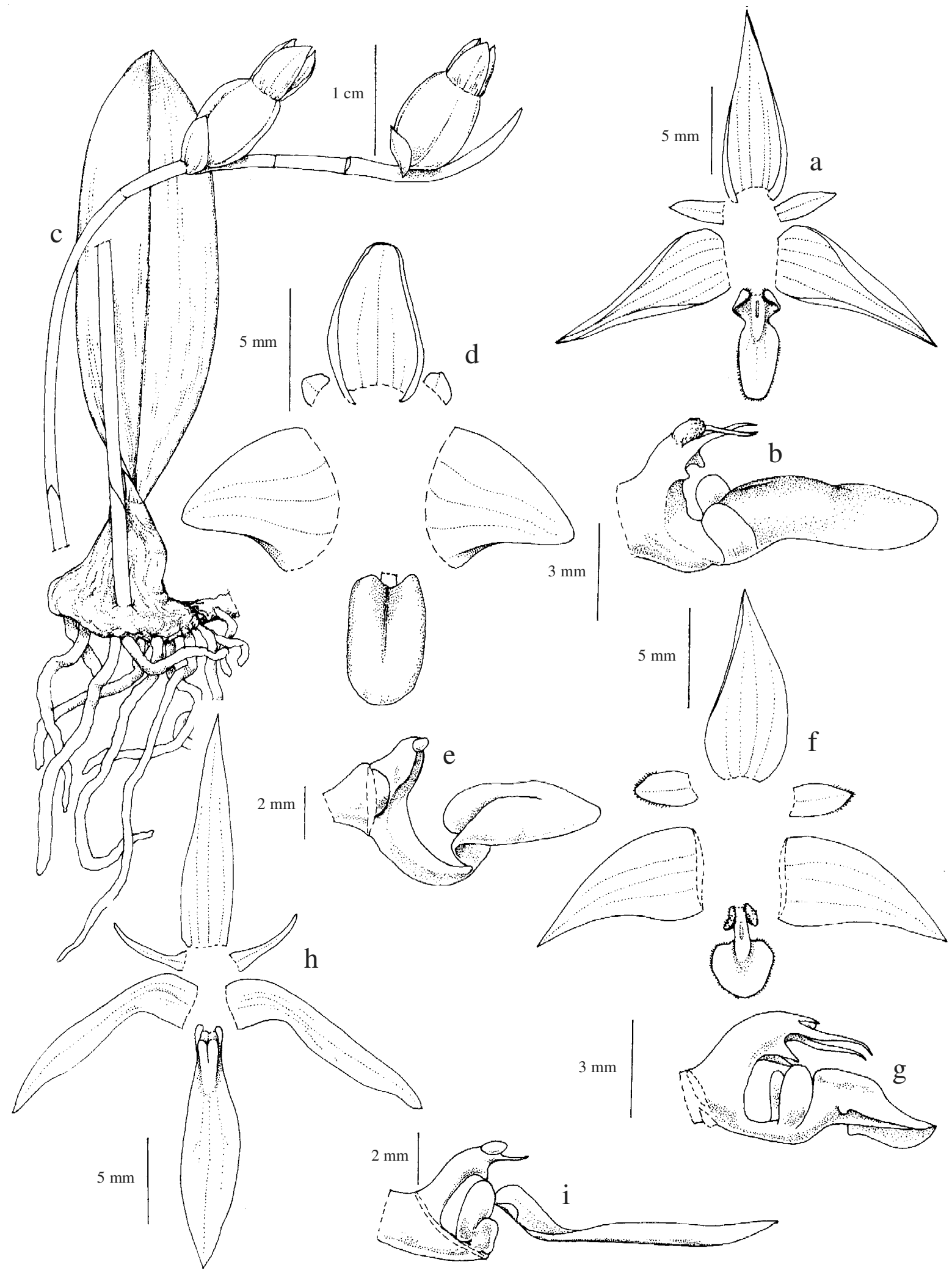

Figura 3a-b. Bulbophyllum ×cipoense. a. Diagrama floral. b. Coluna e labelo em vista lateral (C. Azevedo \& E. Oliveira 182). c-e. Bulbophyllum cribbianum. c. Hábito (C. Azevedo \& R.Oliveira 167). d. Diagrama floral. e. Coluna e labelo em vista lateral (E.L. Borba 2127). f-g. Bulbophyllum involutum. f. Diagrama floral. g. Coluna e labelo em vista lateral (C. Azevedo \& J. Oliveira 149). h-i. Bulbophyllum weddellii. h. Diagrama floral. i. Coluna e labelo em vista lateral (C. Azevedo \& O. Oliveira 140). 
1-1,5 cm comp, 6-15-flora; brácteas florais 1-1,5 x 1-1,5 mm, ovadas, membranáceas, ápice agudo, margem serrilhada. Flores ressupinadas, pedicelo, incluindo o ovário, 2-2,5 mm compr.; sépalas 3,5-4 × 1-1,5 mm, eretas, adnadas na base, lanceoladas, amareladas, membranáceas, ápice reflexo; pétalas 3,5-4 × 0,5-1 mm, eretas, lanceoladas, amareladas, membranáceas, ápice reflexo; labelo ereto, 3-lobado, ovado, amarelado, membranáceo, calcar 2-2,5 $\times$ 0,5-1 mm, lobos laterais 1,5-2,0 $\times 0,5-1,0 \mathrm{~mm}$, eretos envolvendo a coluna, orbiculares, ápice obtuso, lobo terminal 4-4,5 × 2-2,5 mm, lanceolado, ápice agudo; coluna 0,5-1 ×0,5-1 mm, amarelada, polínias 2 .

Material examinado: 27-I-2003, C. Azevedo 173 (HUEFS).

Campylocentrum micranthum ocorre desde o México até o Panamá e também da Venezuela à Bolívia, Guianas, Brasil, Trinidad e Tobago e Antilhas (Dunsterville \& Garay 1961, Sprunger 1991). É amplamente distribuída no Brasil, sendo encontrada nos Estados do Acre, Amazonas, Pará, Amapá, Maranhão, Pernambuco, Bahia, Rio de Janeiro, São Paulo, Minas Gerais, Goiás e Mato Grosso (Pabst \& Dungs 1977). É aqui registrada pela primeira vez para a Chapada Diamantina. É a única espécie epífita encontrada no PMM, rara na área, cresce em galhos finos de árvores e arbustos de matas de grotão. Foi encontrada com flor em janeiro.

Campylocentrum micranthum é facilmente reconhecida por sua forma de crescimento, sendo o único gênero brasileiro de crescimento monopodial (Pabst \& Dungs 1975), além de sua inflorescência lateral mais curta que as folhas e pela presença de calcar. Dunsterville \& Garay (1961) e Sprunger (1991) apresentam uma lista de sinônimos para esta espécie.

\section{Cattleya Lindl.}

Cattleya elongata Barb. Rodr., Gen. spec. Orchid. 1: 72, t.363. 1877. TIPO: BRASIL, Barbosa Rodrigues s.n. (perdido). Lectótipo: ilustração original preparada por João Barbosa Rodrigues, t. 363, que consta de sua Iconographie des orchidées du Brésil, depositada no Herbário Oakes Ames, na Universidade de Harvard, reproduzida por Sprunger et al. (1996) sob o número t.48 do volume 4 , aqui designado.

Figuras 5a-c, 17a

Erva rupícola. Rizoma 5-10 mm compr. entre pseudobulbos. Pseudobulbos 10-32 × 0,7-1,5 cm, 2-3-foliados, eretos, cilíndricos, verde-arroxeados, cobertos por bainhas. Folhas $6-11 \times 3-5 \mathrm{~cm}$, sésseis, sub-eretas a patentes, elípticas a oblongas, verdes, fortemente coriáceas, ápice retuso. Inflorescência em racemo terminal, ereto, espata $5-9 \times 1 \mathrm{~cm}$, oblíqua, ápice apiculado, base amplectiva; pedúnculo (10-)46-50 cm, vermelho-amarronzado; brácteas do pedúnculo $5-7 \times 3-5 \mathrm{~mm}$, triangulares a ovadas, paleáceas, ápice agudo; raque $3-11 \mathrm{~cm}$ compr., 1-6(-12)-flora; brácteas florais 4-5 × 2-3 mm, triangulares a ovadas, membranáceas, ápice agudo. Flores ressupinadas, pedicelo, incluindo o ovário, 3,5-5 cm compr.; sépalas patentes, oblongolanceoladas, vermelho-amarronzadas, carnosas, ápice acuminado, margem revoluta, a dorsal 40-45 × $10-15 \mathrm{~mm}$, as laterais $35-40 \times 10-15 \mathrm{~mm}$; pétalas 40-45 × 10-15 mm, patentes, oblongo-lanceoladas, vermelho-amarronzadas, carnosas, ápice acuminado, margem ondulada; labelo ereto, 3-lobado, magenta, carnoso, 2 calos conspícuos centrais e 2-3 laterais menores, lobos laterais $25-30 \times 10-15 \mathrm{~mm}$, eretos envolvendo completamente a coluna, triangulares, ápice agudo sobreposto, lobo terminal 22-25 $\times$ 20-25 mm, 2-lobulado, transversalmente oblongo, ápice emarginado; coluna 20-25 × 10-15 mm, branca, polínias 4.

Material examinado: 20-II-2003, C. Azevedo \& T.C. Faustino 179 (HUEFS); Unidade de Manejo Sustentável, 4-I-1997, UMS 123 (HRB); idem, 5-IV-1997, UMS 210 (HRB).

Material adicional examinado: BRASIL. BAHIA: South of Andaraí, 14-II-1977, R.M. Harley et al. 18690 (CEPEC, K); Mucugê, Serra do Sincorá, 27-III-1980, R.M. Harley et al. 21024 (CEPEC, K); Mucugê, Serra do Sincorá, 9-V-1976, C.E. Calderon et al. 2422 (CEPEC); Margem da estrada Andaraí-Mucugê, 21-VII-1981, CFCR 1672 (K, SPF); a 7 km, estrada Mucugê/Andaraí, 23-V-1985, W.N. Fonseca \& A.P. Araújo 451 (HRB); nova rodovia Mucugê/Andaraí, 19-V-1989, L.A. Matos Silva et al. 2788 (CEPEC).

Descrita originalmente de material proveniente de Carangola, Minas Gerais (Barbosa-Rodrigues 1877), esta espécie foi citada também para os Estados de Pernambuco e Bahia (Pabst \& Dungs 1975, Sprunger et al. 1996), sendo restrita ao Brasil. Ocorre ao longo da Chapada Diamantina (Cruz at al. 2003), tendo sido citada para Morro do Chapéu, Serra do Sincorá (Harley \& Mayo 1980), Mucugê/Andaraí (Harley \& 


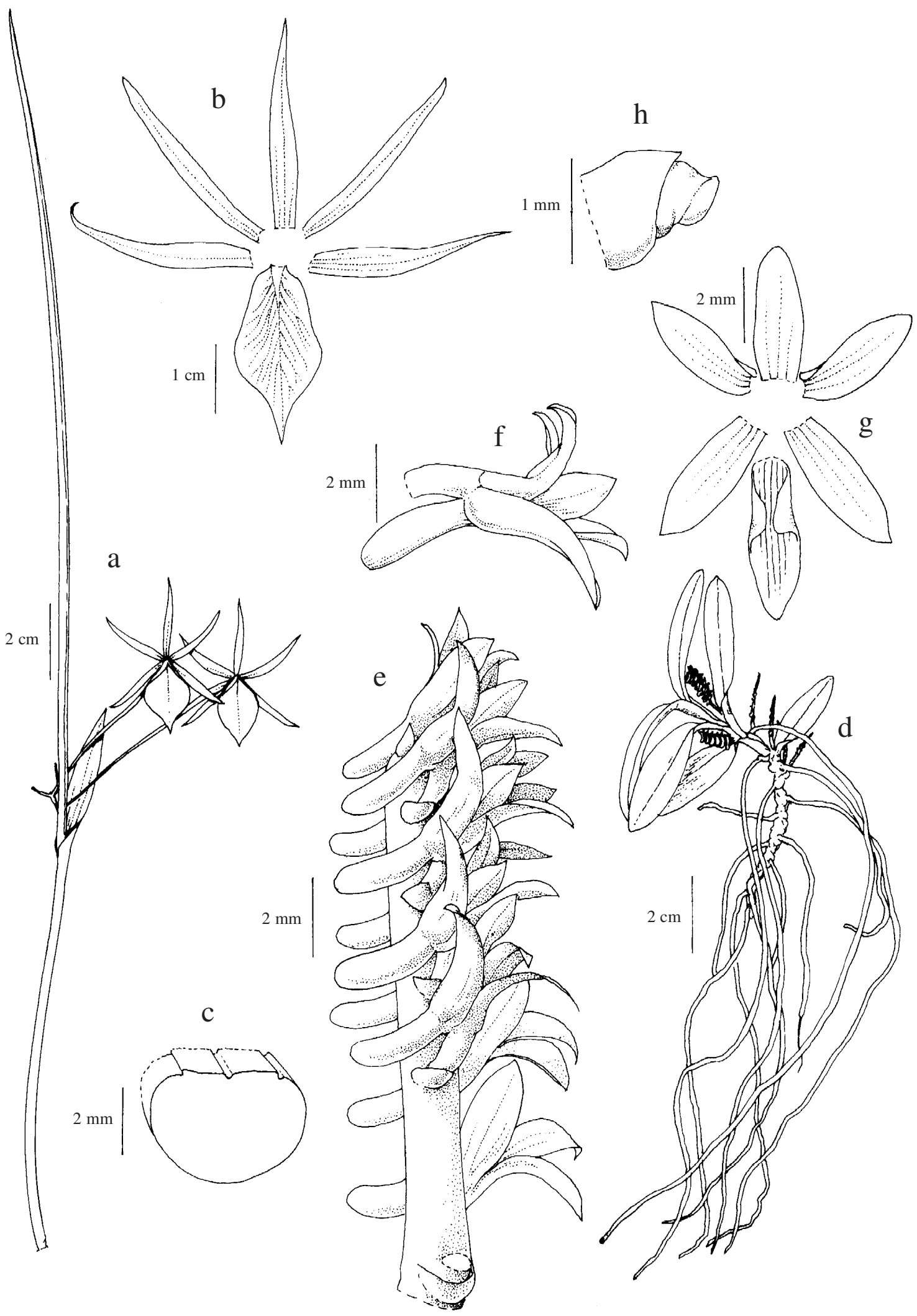

Figura 4a-c. Brassavola tuberculata. a. Hábito. b. Diagrama floral. c. Folha em corte transversal (C. Azevedo \& R. Oliveira 165). d-h. Campylocentrum micranthum. d. Hábito. e. Inflorescência em detalhe. f. Flor em vista lateral. g. Diagrama floral. h. Coluna em vista lateral (C. Azevedo 173). 
Simmons 1986), Rio de Contas (Toscano-de-Brito 1995), Lençóis (Toscano-de-Brito 1998), Palmeiras (Toscano-de-Brito 1998, Conceição \& Giulietti 2002) e Catolés (Toscano-de-Brito \& Queiroz 2003). É comum no Parque e cresce a pleno sol, diretamente sobre rochas. Floresce entre janeiro e maio.

Em 1892, plantas de Cattleya elongata foram exportadas para a Inglaterra, onde foram descritas como Cattleya alexandrae Rolfe. Mais tarde, o próprio Rolfe (1894) reconheceu que a espécie descrita por ele era a mesma descrita anteriormente por Barbosa-Rodrigues.

É facilmente reconhecida por apresentar pseudobulbos cilíndricos alongados, 2-3-foliados e por suas grandes flores vermelho-amarronzadas, de labelo magenta, cujos lobos envolvem completamente a coluna. Uma lista de sinônimos é apresentada em Sprunger et al. (1996).

Cleistes L.C.Rich. ex Lindl.

Cleistes exilis Hoehne, Comm. Linh. Telegr. Matto Grosso Amoz. Annexo 5 Bot. 9: 26, t. 167, f. 1. 1916.

Figuras 5d-f, 17b

Erva terrestre. Raízes com segmentos espessados, 10-15 ×5-10 mm, formando tuberóides e segmentos mais fino. Caule 450-700 × 1-5 mm, ereto, cilíndrico, verde, 3-4-foliado. Folhas 10-20 ×3-4 mm, dísticas, sésseis, eretas, oblongas a ovadas, verdes, membranáceas, ápice agudo. Inflorescência em racemo terminal, ereto; raque $15-20 \mathrm{~cm}$ compr., 1-3flora; brácteas florais foliáceas 10-20 × 2-3 mm, ovadas, membranáceas, ápice agudo. Flores ressupinadas, pedicelo, incluindo o ovário, 15-20 mm compr.; sépalas eretas, lanceoladas, róseas, membranáceas, ápice agudo, a dorsal 25-30 ×5-8 mm, as laterais 20$25 \times 4-5 \mathrm{~mm}$; pétalas $20-25 \times 5-7 \mathrm{~mm}$, eretas, lanceoladas, róseas, membranáceas, ápice agudo; labelo ereto, 3-lobado, róseo, com calosidade amarela, membranáceo, calosidade papilosa em todo comprimento central do labelo, lobos laterais 10-15× 3-3,5 mm, envolvendo a coluna, semi-obovados, ápice obtuso, lobo terminal 6-7 $\times 4-5 \mathrm{~mm}$, ereto, orbicular, ápice reflexo, margem ondulada; coluna 10-13 $\times$ 2-3 mm, rósea, polínias 2.

Material examinado: 20-II-2003, C. Azevedo et al. 178 (HUEFS).

Materiais adicionais examinados: BRASIL. BAHIA: entre Andaraí e Mucugê, 15-II-1974, A. Ghillány s.n.
(HB63141); Serra do Sincorá, 16-II-1977, R.M. Harley et al. 18765 (CEPEC, HB, HRB, K); Mucugê, Serra do Sincorá, 4-II-1974, R.M. Harley et al. 15941 (CEPEC, K); idem, 26-III-1980, R.M. Harley et al. 20984 (CEPEC, K); idem, 26-III-1980, R.M. Harley et al. 20986 (CEPEC, K).

Restrita ao Brasil, foi citada para Minas Gerais (Hoehne 1940), Goiás (Pabst \& Dungs 1975), e na Bahia para a Chapada Diamantina, nos municípios de Mucugê/Andaraí (Harley \& Mayo 1980, Harley \& Simmons 1986), Rio de Contas (Toscano-de-Brito 1995), Lençóis (Toscano-de-Brito 1998) e Catolés (Toscano-de-Brito \& Queiroz 2003). Segundo Silva (2002), Cleistes exilis é comum na Chapada Diamantina, ocorrendo nos municípios de Abaíra, Andaraí, Lençóis, Mucugê, Piatã e Rio de Contas. Cresce em áreas abertas e ensolaradas, dominadas por gramíneas, em solo arenoso. Floresce entre fevereiro e abril.

No Parque, Cleistes exilis é facilmente reconhecida pelo porte esguio e delicado, pelo tamanho muito reduzido de suas folhas, e pela coloração rósea de suas flores. A morfologia do labelo é bastante variável, principalmente na forma do lóbulo terminal. É difícil de ser encontrada, pois a planta fenesce logo após a floração e frutificação, restando apenas o tuberóide subterrâneo, que brota novamente na floração seguinte.

\section{Cyrtopodium R.Br.}

Chave de identificação para as espécies de Cyrtopodium ocorrentes no Parque Municipal de Mucugê

1. Flor branca com máculas purpúreas; brácteas, sépalas e pétalas fortemente onduladas C. aliciae

1. Flor amarelo-esverdeada a marromavermelhada; brácteas, sépalas e pétalas planas ou fracamente onduladas. C. polyphyllum

Cyrtopodium aliciae L. Linden \& Rolfe, Lindenia 8: 73, pl. 371. 1892.

Cyrtopodium edmundoi Pabst, Orquideologia 6(4): 207. 1971. Bradea 1(8): 54, fig. C. 1971.

Figuras 6a-c, 17c

Erva rupícola. Rizoma inconspícuo. Pseudobulbos 30-33 $\times 4-5 \mathrm{~cm}$, eretos, fusiformes, marrons. Folhas 30-35 × 1-1,5 cm, dísticas, sésseis, eretas, plicadas, 


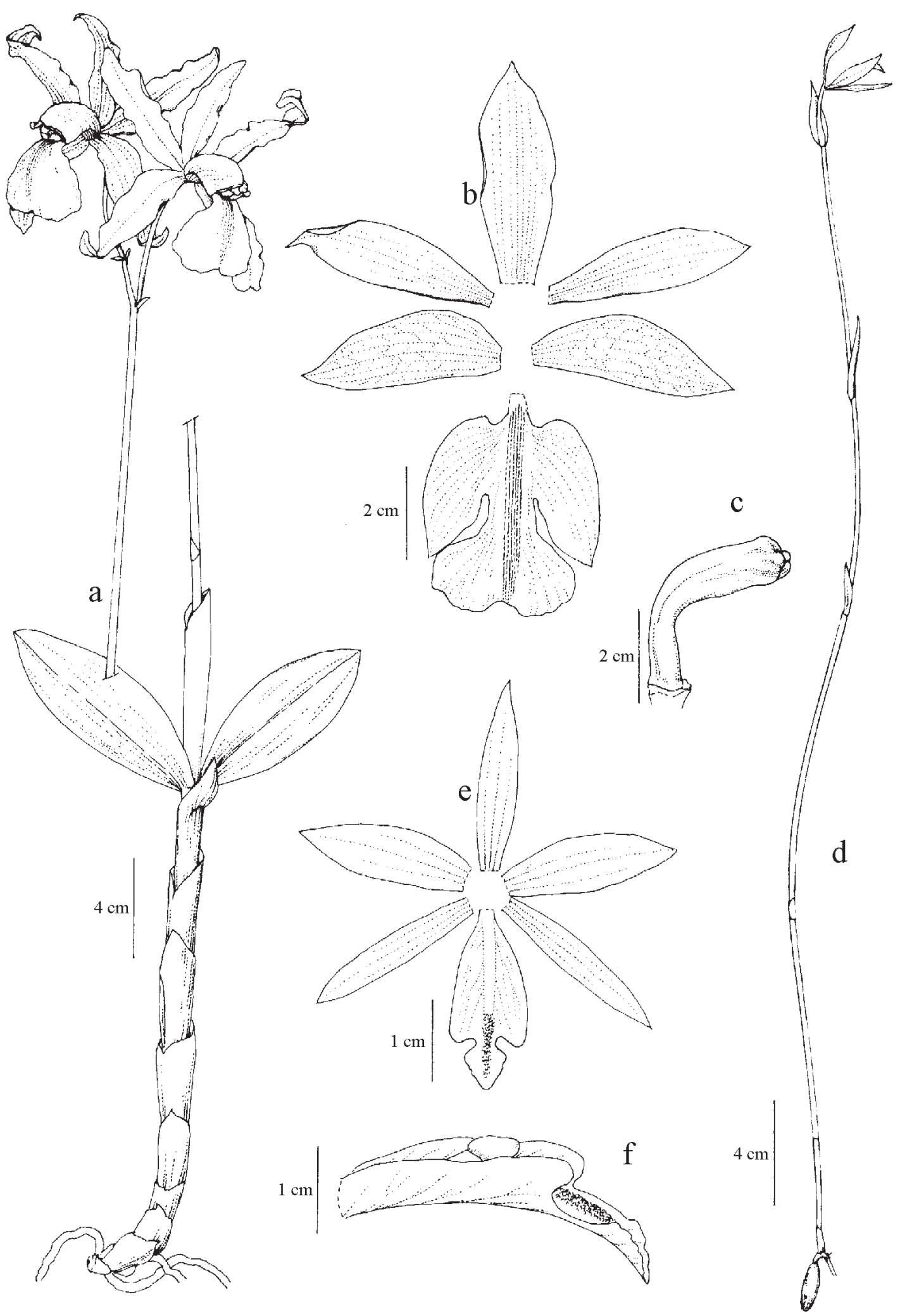

Figura 5a-c. Cattleya elongata. a. Hábito. b. Diagrama floral. c. Coluna em vista lateral (C. Azevedo \& T.C. Faustino 179). d-f. Cleistes exilis. d. Hábito. e. Diagrama floral. f. Coluna e labelo em vista lateral (C. Azevedo et al. 178). 
lineares, verdes, membranáceas, ápice agudo. Inflorescência em panícula lateral, ereta; pedúnculo 65-75 cm compr., verde; brácteas do pedúnculo 25-30 × 10-15 mm, ovadas, paleáceas, ápice agudo, base amplectiva; raque $35-50 \mathrm{~cm}$ compr., 30-flora; brácteas florais $20-25 \times 10-15 \mathrm{~mm}$, ovadas, com a mesma coloração das sépalas, membranáceas, ápice caudado, margem ondulada. Flores ressupinadas, pedicelo, incluindo o ovário, 20-25 mm compr.; sépalas 15-20× 10-15 mm, ovadas, brancas com máculas purpúreas, membranáceas, ápice caudado, margem ondulada, a dorsal patente, as laterais reflexas; pétalas 15-20 × 10-15 mm, reflexas, obovadas, brancas com máculas purpúreas, membranáceas, ápice agudo, margens onduladas; labelo articulado com o pé da coluna, ereto, 3-lobado, branco com máculas purpúreas, calo amarelo, membranáceo, base atenuada, calo convexo, verrugoso, lobos laterais $9-10 \times 6-7 \mathrm{~mm}$, eretos, obovados, ápice obtuso, lobo terminal 8-11 ×5-7 mm, obovado a orbicular, ápice caudado, margem ondulada; coluna 5-7 × 2-3 $\mathrm{mm}$, rósea, prolongada na base em pé de 3-4 mm compr., polínias 4.

Materiais examinados: 15-VIII-2002, C. Azevedo \& O.A. Oliveira 147 (HUEFS); Unidade de Manejo Sustentável, 2-XI-1996, UMS 342 (HRB).

Materiais adicionais examinados: BRASIL. BAHIA: Mucugê, Estrada nova Andaraí-Mucugê, 8-IX-1981, CFCR 1587 (K, SPF); idem, Próximo ao cemitério, 6-IX-1981, CFCR 1904 (K, SPF); idem, a $3 \mathrm{~km}$ da cidade em direção a Igatu, 22-VIII-1986, J.D.C. Arouck Ferreira et al. 363 (HRB); idem, a $1 \mathrm{~km}$ ao N, 10-X-1987, M.L. Guedes et al. 1428 (ALCB); idem, 10-X-1987, L.P. Queiroz 1850 (HUEFS).

Citado para a Argentina e, no Brasil, para a Bahia (Pabst \& Dungs 1975) e Pernambuco (Hoehne 1942, Pabst \& Dungs 1975), em Minas Gerais é conhecido para Grão-Mogol, identificado como Cyrtopodium edmundoi (Barros \& Pinheiro 2004). Cyrtopodium edmundoi foi descrito originalmente para a Bahia, entre Palmeiras e Lençóis (Pabst 1971). Na Chapada Diamantina também foi citado desta forma para Mucugê/Andaraí (Harley \& Simmons 1986), Rio de Contas (Toscano-de-Brito 1995), Lençóis (Toscano-de-Brito 1998), Palmeiras (Toscano-de-Brito 1998, Conceição \& Giulietti 2002) e Catolés (Toscano-de-Brito \& Queiroz 2003). Crescem nos campos rupestres, em áreas abertas ensolaradas, encontradas em flor nos meses de julho, agosto e novembro.
Cyrtopodium aliciae é reconhecida pela coloração branca com máculas purpúreas e forma de seus segmentos florais de margens onduladas.

Cyrtopodium polyphyllum (Vell.) Pabst ex F. Barros, Acta Bot. Brasil. 8(1): 12. 1994. Epidendrum polyphyllum Vell., Fl. flumin. Ic. 9:t. 17. 1827.

Cyrtopodium paranaense Schltr., Repert. Spec. Nov. Regni Veg. 16: 333. 1920.

Figuras 6d-e, 17d

Erva rupícola. Rizoma inconspícuo. Pseudobulbos 25-49 $\times 3$-4 cm, eretos, fusiformes, marrons. Folhas 20-27 × 0,5-1 cm, dísticas, sésseis, eretas, plicadas, lineares a lanceoladas, verdes, membranáceas, ápice agudo. Inflorescência em panícula lateral, ereta; pedúnculo $65-70 \mathrm{~cm}$ compr., verde; brácteas do pedúnculo 40-60×15-30 mm, ovadas, paleáceas, ápice truncado a agudo, base amplectiva; raque $30-40 \mathrm{~cm}$ compr., 40-45-flora; brácteas florais 15-25 ×5-10 mm, lanceoladas, elípticas a ovadas, com a mesma coloração das sépalas, membranáceas, ápice acuminado. Flores ressupinadas, pedicelo, incluindo o ovário, 20-30 mm compr.; sépalas 15-20 × 7-10 mm, patentes, ovadas, amarelo-esverdeadas a marromavermelhada, mais escuras que as pétalas, membranáceas, ápice caudado, margens ligeiramente onduladas; pétalas 15-17 × 7-11 mm, patentes, lanceoladas a orbiculares, amarelas a amarelas com manchas marrom-avermelhadas no ápice, membranáceas, ápice reflexo; labelo articulado com o pé da coluna, ereto, 3-lobado, amarelo, calo avermelhado, membranáceo, calo verrucoso, convexo, lobos laterais 8-10 $\times 5-7 \mathrm{~mm}$, eretos, auriculares a orbiculares, ápice obtuso, lobo terminal 8-10 $\times 10-12 \mathrm{~mm}$, orbicular, ápice retuso; coluna 5-6,5 ×3-4 mm, esverdeada, prolongada na base em pé de $5 \mathrm{~mm}$ compr., amarelo, polínias 4 .

Materiais examinados: 19-IX-2002, C. Azevedo \& E. Ribeiro 155 (HUEFS); 20-IX-2002, C. Azevedo 157 (HUEFS).

Material adicional examinado: BRASIL. BAHIA: Mucugê, 10-X-1987, L.P. Queiroz 1844 (HUEFS).

Cyrtopodium paranaense, hoje considerado sinônimo de Cyrtopodium polyphyllum, foi descrito originalmente para o Estado do Paraná (Schlechter 1920), e citado por Pabst \& Dungs (1975) para Pernambuco, Bahia, Distrito Federal, Rio de Janeiro, São Paulo, Paraná e Santa Catarina. Na Chapada Diamantina, Cyrtopodium polyphyllum é conhecido 


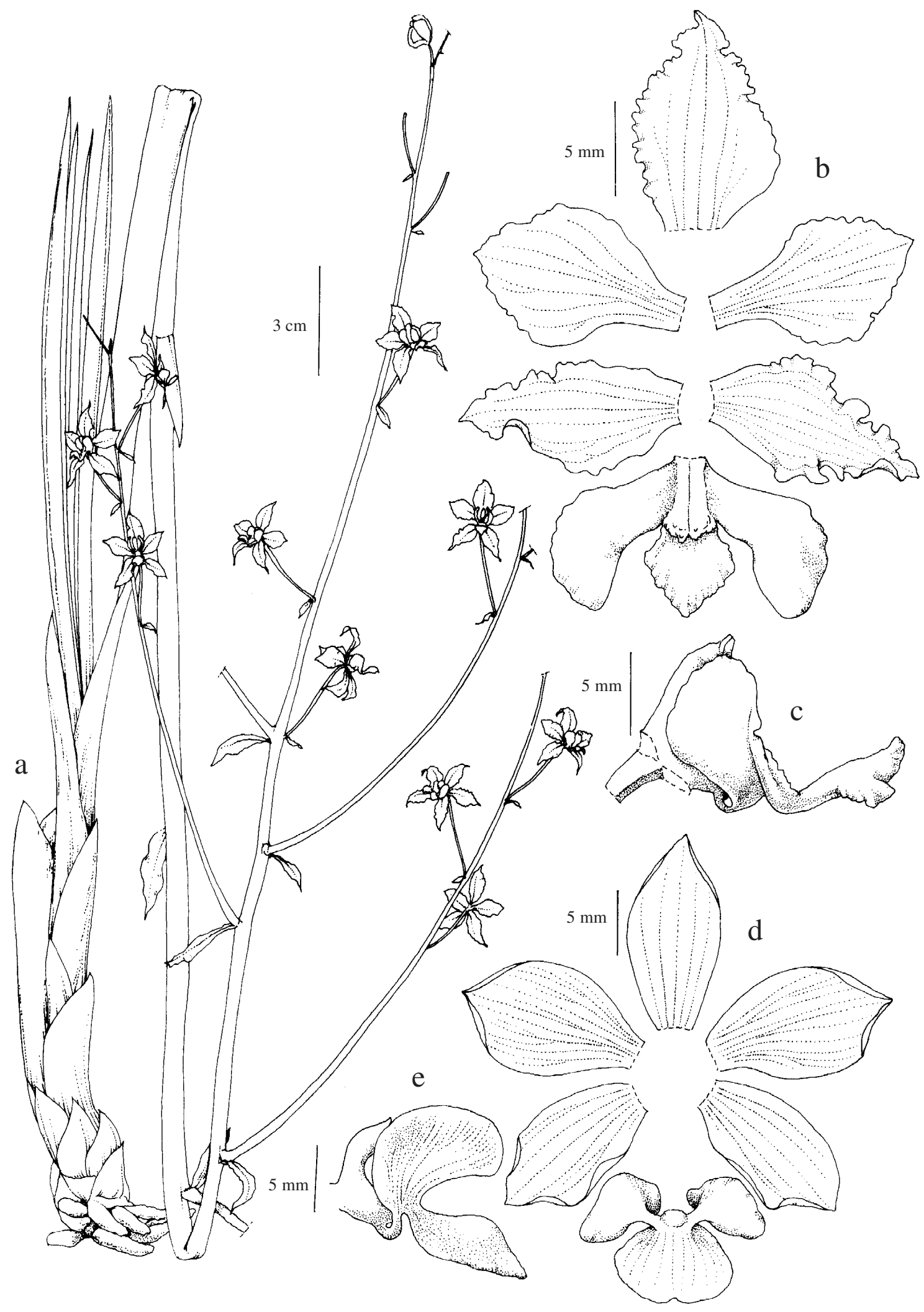

Figura 6a-c. Cyrtopodium aliciae. a. Hábito. b. Diagrama floral. c. Coluna e labelo em vista lateral (C. Azevedo \& O.A. Oliveira 147). d-e. Cyrtopodium polyphyllum. d. Diagrama floral. e. Coluna e labelo em vista lateral (C. Azevedo 157). 
para o município de Lençóis (Toscano-de-Brito 1998), sendo aqui registrado pela primeira vez para o município de Mucugê. Ocorre também nas restingas do litoral do Brasil, crescendo sobre solo arenoso. Floresce entre setembro e outubro.

Epidendrum polyphyllum foi, por muito tempo tratado como sinônimo de Cyrtopodium andersonii R.Br. que é, na verdade, endêmica das Antilhas. Apenas recentemente, passaram a ser consideradas espécies distintas. Barros (1994) considerou que o nome correto desta espécie é Cyrtopodium polyphyllum, com base na ilustração de $E$. polyphyllum na Flora Fluminensis.

Encyclia Hook.

Encyclia alboxanthina Fowlie, Orchid Digest. 54: 26. 1990.

Figuras 7a-c, 17e

Erva rupícola. Rizoma inconspícuo. Pseudobulbos 5-8 $\times$ 2-4 cm, 2-4-foliados, eretos, ovóides, verdes. Folhas 20-30 $\times 2-3 \mathrm{~cm}$, sésseis, sub-eretas a eretas, lanceoladas, verdes, coriáceas, ápice mucronado. Inflorescência em panícula terminal, ereta; pedúnculo 65-80 cm compr., verde; brácteas do pedúnculo 6-10 $\times 10-12 \mathrm{~mm}$, ovadas a orbiculares, paleáceas, ápice agudo, base amplectiva; raque $45-50 \mathrm{~cm}$ compr., 8-30-flora; brácteas florais 3-5 × 2-3 mm, ovadas, paleáceas, ápice agudo. Flores ressupinadas, pedicelo, incluindo o ovário, 2,5-3 cm compr.; sépalas 20-25 × 8-10 mm, patentes, amarelo-esverdeadas com estrias vináceas, membranáceas, ápice apiculado, a dorsal levemente obovada, as laterais lanceoladas; pétalas 20-25 × 7-10 mm, patentes, espatuladas, amareloesverdeadas com estrias vináceas, membranáceas, ápice apiculado; labelo coalescente à base da coluna, ereto, 3-lobado, branco com linhas purpúreas no lobo terminal, disco amarelo, membranáceo, disco carnoso, com duas carenas, lobos laterais 8-11 × 5-6 mm, envolvendo a coluna e então reflexos, obtusos, ápice obtuso, lobo terminal 15-18 $\times 11-13 \mathrm{~mm}$, orbicular, ápice agudo, margem ligeiramente ondulada; coluna $12-13 \times 5-6 \mathrm{~mm}$, amarelo-esverdeada, provida de dois braços voltados para baixo, polínias 4 .

Materiais examinados: 18-X-2002, C. Azevedo 159 (HUEFS); Projeto Sempre-Viva, 16-XII-1999, L.P. Queiroz et al. 5585 (HUEFS); idem, 24-X-2000, E.R. Souza et al. 88 (HUEFS); Unidade de Manejo
Sustentável, 3-I-1997, UMS 70 (HRB); idem, 6-IV-1997, UMS 284 (HRB); idem, 2-XI-1996, UMS 348 (HRB).

Material adicional examinado: BRASIL. BAHIA: $10 \mathrm{~km}$ S. of Andaraí, 16-II-1977, R.M. Harley et al. 18767 (ALCB, CEPEC, HUEFS, K); estrada entre Andaraí e Mucugê, 20-XI-1983, L.R. Noblick \& A. Pinto 2883 (HUEFS); Mucugê, 6-XII-1980, CFCR 434 (K, SPF); idem, 3-5 km N da cidade, 20-II-1994, CFCR 14263 (K, SPF); Beira da estrada para Andaraí, 16-XII-1984, CFCR 7016 (K, SPF); Rio Cumbuca, 4-II-1974, R.M. Harley et al. 15962 (CEPEC, K); Serra do Capa Bode, XI-1973, G.C.P. Pinto s.n. (ALCB477, HRB31060).

Endêmica da Chapada Diamantina, foi descrita originalmente para o município de Mucugê (Fowlie 1990), foi citada para Lençóis (Toscano-de-Brito 1998) e Catolés (Toscano-de-Brito \& Queiroz 2003), e com outros nomes para a Serra do Curral Feio e Serra do Sincorá, como Encyclia advena (Rchb. f.) Porto \& Brade e Encyclia osmantha (Barb. Rodr.) Schltr. (Harley \& Mayo 1980), para Mucugê/Andaraí como E. advena (Harley \& Simmons 1986) e no Plano de Manejo do Parque, como E. advena.

Esta espécie foi por muito tempo confundida com Encyclia advena e Encyclia osmantha, até ser descrita como espécie nova por Fowlie (1990). Encyclia advena foi sempre um nome de aplicação controversa, até ser mais recentemente aplicado à espécie comumente chamada de Encyclia megalantha (Barb. Rodr.) Porto \& Brade (Castro \& Campacci 2000). Encyclia alboxanthina difere de Encyclia osmantha por suas plantas e flores bem maiores, labelo branco, por vezes maculado, e de textura lisa, hastes florais muito mais longas e por ser de hábito exclusivamente rupícola na Chapada Diamantina, enquanto $E$. osmantha é uma espécie epífita nas matas de galeria em vegetação de cerrado em Minas Gerais, Goiás e Sudoeste da Bahia e apresenta rugosidades sobre as venulações do labelo. Encyclia alboxanthina é abundante nos campos rupestres do Parque, crescendo diretamente sobre as rochas a pleno sol, muitas vezes ao lado de Cattleya elongata. Floresce entre outubro e fevereiro.

No Parque, Encyclia alboxanthina é reconhecida por suas longas inflorescências e grande quantidade de flores de coloração amareloesverdeadas com estrias vináceas e labelo branco com linhas purpúreas. 


\section{Epidendrum L.}

Chave de identificação para as espécies de Epidendrum ocorrentes no Parque Municipal de Mucugê

1. Inflorescência ereta, com 36-71 cm compr., pedúnculo mais longo que a raque, brácteas do pedúnculo não imbricadas

2. Flores ressupinadas, marrom-esverdeadas; labelo com margem inteira E. orchidiflorum

2. Flores não ressupinadas, róseas; labelo com margem denticulada E. secundum

1. Inflorescência pendente, com 11-23 cm compr., pedúnculo mais curto que a raque; brácteas do pedúnculo imbricadas

3. Flores amarelas com máculas vináceas; labelo amarelo com máculas vináceas, de margem laciniada E. cristatum

3. Flores marrom-esverdeadas sem máculas; labelo branco-esverdeado sem máculas, de margem inteira E. warasii

Epidendrum cristatum Ruiz \& Pav., Syst. Veg. Fl. Peruv. Chil. 1: 243. 1798.

Figura $8 \mathrm{a}, \mathrm{b}, 17 \mathrm{f}$

Erva terrestre. Rizoma inconspícuo. Caule 150-200 × 1-2 cm, ereto, cilíndrico, verde, coberto por 7-12 folhas. Folhas 10-15 ×1,5-2 cm, dísticas, sésseis, sub-eretas, oblongas, verdes, semicoriáceas, ápice obtuso, articuladas com a bainha. Inflorescência em racemo terminal, pendente; pedúnculo 8-10 cm compr., vináceo; brácteas do pedúnculo 50-75 × 10-15 mm, oblongas, imbricadas, paleáceas, ápice agudo; raque 10-15 cm compr., 25-30-flora; brácteas florais 3-8 $\times$ 1-2 mm, triangulares, paleáceas, ápice agudo. Flores ressupinadas, pedicelo, incluindo o ovário, $40-45 \mathrm{~mm}$ compr.; sépalas reflexas, lanceoladas, amareladas com máculas vináceas, membranáceas, ápice agudo, a dorsal 15-20 × 4-6 mm, as laterais 15-17 × 5-6 mm; pétalas $15-17 \times 4-5 \mathrm{~mm}$, reflexas, obovadas, amareladas com máculas vináceas, menos máculas que nas sépalas, membranáceas, ápice agudo; labelo 10-15 × 10-15 mm, coalescente à face adaxial em toda extensão da coluna, patente, 3-lobado, orbicular, amarelado com máculas vináceas, membranáceo, margem laciniada, lobos laterais patentes, orbiculares, ápice obtuso, lobo terminal patente, reflexo, dividido em lóbulos, lineares, ápice obtuso; coluna 10-15 ×3 mm, branca com ápice vináceo, polínias 4 .

Material examinado: 20-IX-2002, C. Azevedo 156 (HUEFS).

Material adicional examinado: BRASIL. BAHIA: Mucugê, 14-X-1996, M.C. Ferreira 1199 (HRB).

Citada para Colômbia, Venezuela, Guiana, Suriname, Brasil, Equador, Peru e Bolívia (Bennett \& Christenson 1993, Sprunger et al. 1996), no Brasil ocorre nos Estados de Minas Gerais, Espírito Santo, Rio de Janeiro, São Paulo, Paraná, Santa Catarina e Rio Grande do Sul (Pabst \& Dungs 1975, Sprunger et al. 1996). Na Bahia, foi citada para Catolés (Toscano-de-Brito \& Queiroz 2003), sendo aqui registrada, pela primeira vez, para o município de Mucugê. Floresce entre setembro e outubro.

Esta espécie é altamente variável, tanto vegetativamente quanto em suas partes florais e, como conseqüência, foi descrita várias vezes, apresentando um grande número de sinônimos. Assemelha-se vegetativamente a Epidendrum warasii pelo porte alto de suas plantas, que chegam a $2 \mathrm{~m}$ de altura, embora diferencie-se por apresentar folhas mais longas e de textura mais fina. As duas apresentam pedúnculo mais curto que a raque, brácteas do pedúnculo longas e imbricadas, mas diferenciam-se na coloração e formato de suas flores, já que Epidendrum cristatum tem flores amareladas com máculas vináceas e labelo de margem laciniada.

Epidendrum orchidiflorum Salzm. ex Lindl., Gen. Sp. Orchid. pl.103. 1831.

Epidendrum huebneri Schltr., Beih. Bot. Centralbl. 42, pt 2: 99. 1925.

Figuras $8 \mathrm{c}, 17 \mathrm{~g}$

Erva rupícola. Rizoma inconspícuo. Caule 16-40 × 0,5-1 cm, ereto, cilíndrico, marrom, coberto pelas bainhas das folhas, 6-22-foliado. Folhas 4-5 ×1-2 cm, dísticas, sésseis, sub-eretas, lanceoladas, verdes, coriáceas, ápice agudo, articulada com as bainhas. Inflorescência em racemo terminal, ereta; pedúnculo 50-65 cm compr., marrom-esverdeado; brácteas do pedúnculo 30-45 × 5-10 mm, oblongas, paleáceas, ápice agudo, base amplectiva; raque 3-6 cm compr., 5-10-flora; brácteas florais 4-7 $\times 1-2 \mathrm{~mm}$, triangulares, 
membranáceas, ápice agudo. Flores ressupinadas, pedicelo, incluindo o ovário, 20-25 mm compr.; sépalas patentes, marrom-esverdeadas, membranáceas, ápice agudo, a dorsal 10-15 $\times 5-6 \mathrm{~mm}$, obovada, as laterais 10-12 × 5-6 mm, oblongo-obovadas; pétalas 10-12 $\times$ 1-2 mm, patentes, lineares, marrom-esverdeadas, membranáceas, ápice agudo; labelo 8,0-10 × $15 \mathrm{~mm}$, coalescente à face adaxial em toda extensão da coluna, patente, inteiro, orbicular, marrom-esverdeado, carnoso, ápice retuso; coluna 6-7 × 2,5-3 mm, marromesverdeada, polínias 4.

Materiais examinados: 11-VI-2002, C. Azevedo \& J. Oliveira 138 (HUEFS); Unidade de Manejo Sustentável, 12-I-1997, UMS 159 (HRB); idem, 2-XI-1996, UMS 346 (HRB).

Materiais adicionais examinados: BRASIL. BAHIA: Mucugê, 29-VI-1997, M.L. Guedes et al. 5109 (ALCB); idem, 31-I-1997, PCD 4745 (HUEFS).

Descrito originalmente de material proveniente da Bahia (Lindley 1831), Epidendrum orchidiflorum foi citado para os Estados de Alagoas e Bahia (Pabst \& Dungs 1975) Amazonas, Roraima, Para, Sergipe e Rio de Janeiro (Sprunger et al. 1996), e para a Venezuela, Guiana e Peru (Bennett \& Christenson 1993, Sprunger et al. 1996). Na Chapada Diamantina foi citado para os municípios de Lençóis (Toscanode-Brito 1998), Palmeiras (Toscano-de-Brito 1998, Conceição \& Giulietti 2002), e no município de Mucugê, para o PMM (Stradmann 1998). Comum na área do Parque, Epidendrum orchidiflorum ocorre em vários ambientes da reserva. Foi observado em flor entre novembro e janeiro, e no mês de julho.

Embora Pabst \& Dungs (1975) considerem Epidendrum orchidiflorum e Epidendrum huebneri como espécies distintas, Bennett \& Christenson (1993) consideram $E$. huebneri sinônimo de E. orchidiflorum, além de outros sinônimos: Epidendrum caespitosum Barb. Rodr., Epidendrum rectopedunculatum C. Schweinf., Epidendrum acrirachis Pabst e Epidendrum garayanum Hawkes. A mesma delimitação foi seguida por Sprunger et al. (1996), sendo adotada neste trabalho.

Epidendrum secundum Jacq., Enum. Syst. Pl. 29.1760. Epidendrum elongatum Jacq., Coll. 3: 260. 1789.

Epidendrum ellipticum Grah., Edinb. N. Phil. J. 1: 171.1826.

Epidendrum crassifolium Lindl., Gen. et Sp. Orch. 107. 1831.

Figuras 8d, 17h
Erva terrestre. Rizoma inconspícuo. Caule (7-)20 $27 \times 0,5-1 \mathrm{~cm}$, ereto, cilíndrico, verde, coberto pelas bainhas das folhas, 6-20-foliado. Folhas 5-8 $\times$ 1-2 cm, dísticas, sésseis, sub-eretas, lanceoladas, verdes, coriáceas, ápice agudo, articulada com as bainhas. Inflorescência em racemo terminal, ereta; pedúnculo (17-24-)33-48 cm compr., verde; brácteas do pedúnculo 35-55 × 2-4 mm, oblongo-lanceoladas, paleáceas, ápice agudo, base amplectiva; raque $3-5 \mathrm{~cm}$ compr., 4-6-flora; brácteas florais 2-5 × $1 \mathrm{~mm}$, ovadas a triangulares, paleáceas, ápice agudo. Flores não ressupinadas, pedicelo, incluindo o ovário, 10-20 mm compr.; sépalas róseas, membranáceas, a dorsal 10-15 × 3-5 mm, reflexa, lanceolada, ápice agudo, as laterais 10-14 $\times 4-5 \mathrm{~mm}$, patentes, oblongas a obovadas, ápice apiculado; pétalas 10-14 × 2-3 mm, patentes, lanceoladas, róseas, membranáceas, ápice agudo; labelo coalescente à face adaxial em toda extensão da coluna, ereto, 3-lobado, orbicular, róseo, membranáceo, margem denticulada, calosidade branca com centro amarelo, lobos laterais 2-3 $\times 2-3 \mathrm{~mm}$, eretos, ovados a orbiculares, ápice obtuso, lobo terminal 3-4,5 $\times$ 3-4,5 mm, ereto, orbicular, ápice agudo; coluna 4-5× 1-2 mm, rósea, polínias 4 .

Materiais examinados: 18-X-2002, C. Azevedo 158 (HUEFS); Unidade de Manejo Sustentável, 6-IV-1997, UMS 262 (HRB); idem, 2-XI-1996, UMS 347 (HRB).

Material adicional examinado: BRASIL. BAHIA: Serra do Sincorá, 6-II-1974, R.M. Harley 16050 (CEPEC, K); estrada entre Andaraí e Mucugê, 20-XI-1983, L.R. Noblick \& A. Pinto 2900 (HUEFS); Mucugê, Estrada Mucugê-Andaraí, 21-II-1994, CFCR 14361 (K, SPF); idem, 8-IX-1981, CFCR 1595 (K, SPF); idem, 8-IX-1981, CFCR 2117 (K, SPF); Serra de São Pedro, 17-XII-1984, CFCR 7068 (K, SPF); PCD 4744 (ALCB, K); caminho para Guiné, 15-II-1997, PCD 5708 (ALCB); estrada Mucugê - Andaraí, 12-XI-1998, R.P. Oliveira et al. 37 (HUEFS); fazenda Paiol, 20-X-1986, R.P. Orlandi et al. 792 (HRB); Guiné, 21-X-2002, E.C. Smidt 289 (HUEFS).

É uma espécie de ampla distribuição geográfica, conhecida para toda a América tropical (Dunsterville \& Garay 1961, Pabst \& Dungs 1975, Sprunger et al. 1996). No Brasil, é citada para os Estados da Amazonas, Amapá, Pará, Ceará, Bahia, Rio de Janeiro, Mato Grosso, Minas Gerais, Goiás, São Paulo, Paraná, Pernambuco, Santa Catarina e Rio Grande do Sul, e para o Distrito Federal, (Pabst \& Dungs 1975). Na Bahia foi citada para Rio de Contas 
(Toscano-de-Brito 1995), Lençóis (Toscano-de-Brito 1998), Palmeiras (Toscano-de-Brito 1998, Conceição \& Giulietti 2002) e Catolés (Toscano-de-Brito \& Queiroz 2003). Para Alcobaça, Ilhéus, Serra do Curral Feio, Serra do Sincorá, Serra das Almas (Harley \& Mayo 1980) e Mucugê/Andaraí (Harley \& Simmons 1986), identificadas como Epidendrum crassifolium e Epidendrum elongatum. Na Cadeia do Espinhaço para a Serra do Cipó (Barros 1987) e Grão-Mogol (Barros \& Pinheiro 2004). Cresce em locais ensolarados, com substratos pedregosos e arenosos. Floresce entre outubro e fevereiro.

Esta espécie é altamente variável, tanto vegetativamente quanto no tamanho, forma e cor de suas flores e por este motivo foi descrita com vários nomes diferentes. Pabst \& Dungs (1975) consideram Epidendrum crassifolium, Epidendrum ellipticum e Epidendrum elongatum espécies distintas, enquanto Sprunger (1991) e Sprunger et al. (1996) consideram E. crassifolium e E. ellipticum sinônimos de E. elongatum. Neste trabalho, seguimos Dunsterville \& Garay (1961), que consideram todos os quatro nomes conspecíficos, além de apresentarem uma longa lista com outros sinônimos, totalizando 37 nomes e ilustrarem a variação de formas do labelo e calo. Entre as outras espécies de Epidendrum do PMM, Epidendrum secundum pode ser reconhecido por suas flores não ressupinadas, pequenas, róseas e pelo labelo com margem denticulada.

Epidendrum warasii Pabst, Orchid. Rev. 79(941): 306. 1971.

Figuras 8e, 17i

Erva rupícola. Rizoma inconspícuo, raízes emergindo de todo o rizoma. Caule $66-200 \times 1,5-2 \mathrm{~cm}$, ereto, cilíndrico, verde, recoberto pelas bainhas das folhas, 8-16-foliado. Folhas 6-7 × 1,5-2 cm, dísticas, sésseis, sub-eretas, ovadas a oblongas, verdes, carnosas, ápice obtuso. Inflorescência em racemo terminal, pendente; pedúnculo $8-9 \mathrm{~cm}$ compr.; brácteas do pedúnculo $30-40 \times 10 \mathrm{~mm}$, ovadas, imbricadas, paleáceas, ápice agudo; raque 30-40 mm compr., 10-15flora; brácteas florais 7-10 × 3-4 mm, ovadas, membranáceas, ápice agudo. Flores ressupinadas, pedicelo, incluindo o ovário, $15-33 \mathrm{~mm}$ compr.; sépalas patentes, lanceoladas, marrom-esverdeadas, membranáceas, a dorsal 15-20 × 5-6 mm, ápice agudo, as laterais 15-20 × 5-7 mm, ápice apiculado; pétalas 10-15 × 3-4 mm, patentes, lanceoladas, marromesverdeadas, membranáceas, ápice apiculado; labelo coalescente à face adaxial em toda extensão da coluna, ereto, 3-lobado, branco-esverdeado, carnoso, disco com 2 calosidades, lobos laterais 7-10 × 3-4 mm, patentes e reflexos, oblongos, ápice obtuso, lobo terminal 5-9 $\times 6-7 \mathrm{~mm}$, patente, orbicular, ápice truncado, mucronado; coluna 8-9 × 3-4 mm, brancaesverdeada, polínias 4.

Material examinado: 20-II-2003, C. Azevedo \& J. Oliveira 176 (HUEFS).

Endêmica da Cadeia do Espinhaço, esta espécie foi citada por Pabst \& Dungs (1975) apenas para o Estado de Minas Gerais e neste, para a Serra do Cipó (Barros 1987) e Grão-Mogol (Barros \& Pinheiro 2004), e também para a Bahia em Rio de Contas (Toscano-de-Brito 1995) e Catolés (Toscano-de-Brito \& Queiroz 2003), sendo aqui registrada para o município de Mucugê, onde cresce em áreas abertas, diretamente sobre as rochas em campo rupestre. Floresce em fevereiro.

É vegetativamente parecida com Epidendrum cristatum, pela altura da planta, que chega a $2 \mathrm{~m}$, diferindo desta por seu porte mais robusto, suas folhas mais curtas e carnosas, além da coloração e formato de suas flores, marrom-esverdeadas e labelo brancoesverdeado, de margem lisa.

\section{Epistephium Kunth}

Epistephium lucidum Cogn., Fl. Bras. 3(4): 141, pl. 30. 1893.

Figuras $7 \mathrm{~d}-\mathrm{f}, 17 \mathrm{j}$

Erva terrestre. Rizoma inconspícuo. Caule 150-200 × 0,5-1 cm, ereto, cilíndrico, verde, 4-11foliado. Folhas (4-)8-11 × 2-4 cm, dísticas, sésseis, sub-eretas, ovadas, verdes, coriáceas, ápice apiculado, base amplectiva, margem ligeiramente reflexa, nervação reticulada. Inflorescência em racemo terminal, ereto; raque $15-26 \mathrm{~cm}$ compr., 1-3-flora; brácteas florais 3-6 × 4-6 mm, ovadas a orbiculares, membranáceas, ápice agudo. Flores ressupinadas, pedicelo, incluindo o ovário, $35-40 \mathrm{~mm}$ compr., presença de epicálice; sépalas 40-50 × 15-20 mm, patentes, lanceoladas, lilás, membranáceas, ápice apiculado; pétalas $40-50 \times 20-25 \mathrm{~mm}$, patentes, obovadas, lilás, membranáceas, ápice obtuso; labelo 50-60 × 40-50 mm, aderente à face lateral da coluna até $1 / 3$ de seu comprimento, os outros $2 / 3$ envolvendo a coluna, ereto, inteiro, obovado, lilás, ápice mais escuro, internamente branco com veias lilás, membranáceo, ápice retuso, margem ondulada, pêlos 
em todo comprimento na porção central do labelo; coluna 30-35 ×5 mm, lilás com ápice branco, polínias 4. Fruto cápsula 40-50 × 5-7 mm, verde.

Materiais examinados: 27-I-2003, C. Azevedo 172 (HUEFS); ca. 4 km N de Mucugê, 23-I-2000, L.P. Queiroz 5619 (HUEFS); Unidade de Manejo Sustentável, 4-I-1997, UMS 114 (HRB).

Material adicional examinado: BRASIL, BAHIA, $2 \mathrm{~km}$ al N de Mucugê, 20-I-1997, M.M. Arbo et al. 7575 (CEPEC, CTES); 3 km S of Mucugê, 4-II-1974, R.M. Harley et al. 15905 (CEPEC, K); $10 \mathrm{~km} \mathrm{~S}$ of Andaraí, 16-II-1977, R.M. Harley et al. 18773 (CEPEC); Mucugê, estrada Andaraí-Mucugê, 8-IX-1981, CFCR 2125 (K, SPF); Serra do Capa Bode, XI-1973, G. Pinto s.n. (ALCB 471).

Restrita ao Brasil, Hoehne (1945) citou a ocorrência de Epistephium lucidum para o Espírito Santo, Rio de Janeiro, São Paulo e Minas Gerais, sendo também conhecida dos Estados da Bahia, Goiás, Roraima e Distrito Federal (Pabst \& Dungs 1975). Na Bahia, foi citada para a Serra de Jacobina, Serra do Sincorá, Serra das Almas e Belmonte (Harley \& Mayo 1980), e para Mucugê/Andaraí (Harley \& Simmons 1986), Palmeiras (Conceição \& Giulietti 2002), Rio de Contas (Toscano-de-Brito 1995) e Catolés (Toscano-de-Brito \& Queiroz 2003). Na porção mineira da Cadeia do Espinhaço, foi citada para a Serra Grão-Mogol (Barros \& Pinheiro 2004). Cresce em áreas abertas e ensolaradas, dominadas por gramíneas, em solo arenoso, ocorrendo também em restinga. Floresce entre janeiro e fevereiro.

Facilmente reconhecida por suas plantas grandes, chegando até a $2 \mathrm{~m}$ de altura, pela nervação reticulada de suas folhas, pela presença de epicálice e por suas flores grandes de cor lilás, que se assemelham a algumas flores de Cattleya.

\section{Habenaria Willd.}

Habenaria fluminensis Hoehne, Arq. Bot. Estado São Paulo n.s. 1: 41, tab. 46. 1939.

Figuras 9a-c, 17k

Erva terrestre. Raízes formando tuberóides. Caule 80-100 × 0,5-1 cm, ereto, cilíndrico, verde, coberto pelas bainhas das folhas, 4-6-foliado. Folhas 20-27 $\times$ $1-1,5 \mathrm{~cm}$, dísticas, sésseis, sub-eretas a eretas, linearlanceoladas, verdes, membranáceas, ápice agudo. Inflorescência em racemo terminal, ereta; raque 20-25 cm compr., 15-17-flora; brácteas florais 2-3 ×
$1 \mathrm{~cm}$, obovadas, membranáceas, ápice caudado. Flores ressupinadas, pedicelo, incluindo o ovário, $2,5-3 \mathrm{~cm}$ compr., sulcado; sépalas esverdeadas, membranáceas, a dorsal 12-15 × 7-9 mm, patente, ovada, ápice acuminado, as laterais $12-14 \times 4-5 \mathrm{~mm}$, reflexas, ovadas a lanceoladas, ápice agudo; pétalas $12-14 \times 4-5 \mathrm{~mm}$, bipartidas até perto da base, reflexas, lineares, esverdeadas, membranáceas, ápice agudo; labelo patente, tripartido, esverdeado, membranáceo, segmentos laterais 15-17 $\times 1-2 \mathrm{~mm}$, patentes, lineares, ápice agudo, segmento mediano 15-16 × 3-4 mm, patente, linear, ápice agudo; cálcar 20-25 × 2-3 mm, dilatado no ápice; coluna $4-5 \times 3-4 \mathrm{~mm}$, verde, polínias 2.

Materiais examinados: 12-VI-2002, C. Azevedo \& O. Oliveira 141 (HUEFS); 13-VII-2002, C. Azevedo 144 (HUEFS).

Descrita originalmente da Serra do Mar em São Paulo e Petrópolis no Rio de Janeiro (Hoehne 1939), esta espécie foi citada também para Minas Gerais (Pabst \& Dungs 1975), Bahia e Espírito Santo (Batista \& Bianchetti 2002). No Estado da Bahia, Harley \& Mayo (1980) citaram sua ocorrência para o município de Morro do Chapéu. É aqui registrada para o município de Mucugê. Cresce em solo arenoso, em área aberta, ensolarada, dominada por gramíneas. Floresce entre junho e julho.

Habenaria fluminensis é facilmente reconhecida no Parque por suas flores esverdeadas, pétalas bipartidas, labelo tripartido e por apresentar um longo cálcar. Planta encontrada apenas no período de floração e frutificação, já que, logo após esta fase, fenesce, perdendo toda parte vegetativa.

Maxillaria Ruiz \& Pav.

Maxillaria notylioglossa Rchb. f., Bonplandia, 2: 16. 1854.

Maxillaria cerifera Barb. Rodr., Gen. spec. Orchid. 1: 118. 1877. TIPO: BRASIL, Barbosa Rodrigues s.n. (perdido). Lectótipo: ilustração original preparada por João Barbosa Rodrigues, que consta de sua Iconographie des orchidées du Brésil, depositada na biblioteca do Jardim Botânico do Rio de Janeiro, reproduzida por Sprunger et al. (1996) sob o número t. 296 do volume 6, aqui designado. Figuras 9d-f, 171

Erva rupícola. Rizoma 5,0-10 mm compr. entre pseudobulbos. Pseudobulbos 10-15 × 5-7 mm, 2-foliados, eretos, ovóides, verdes, cobertos por 2 


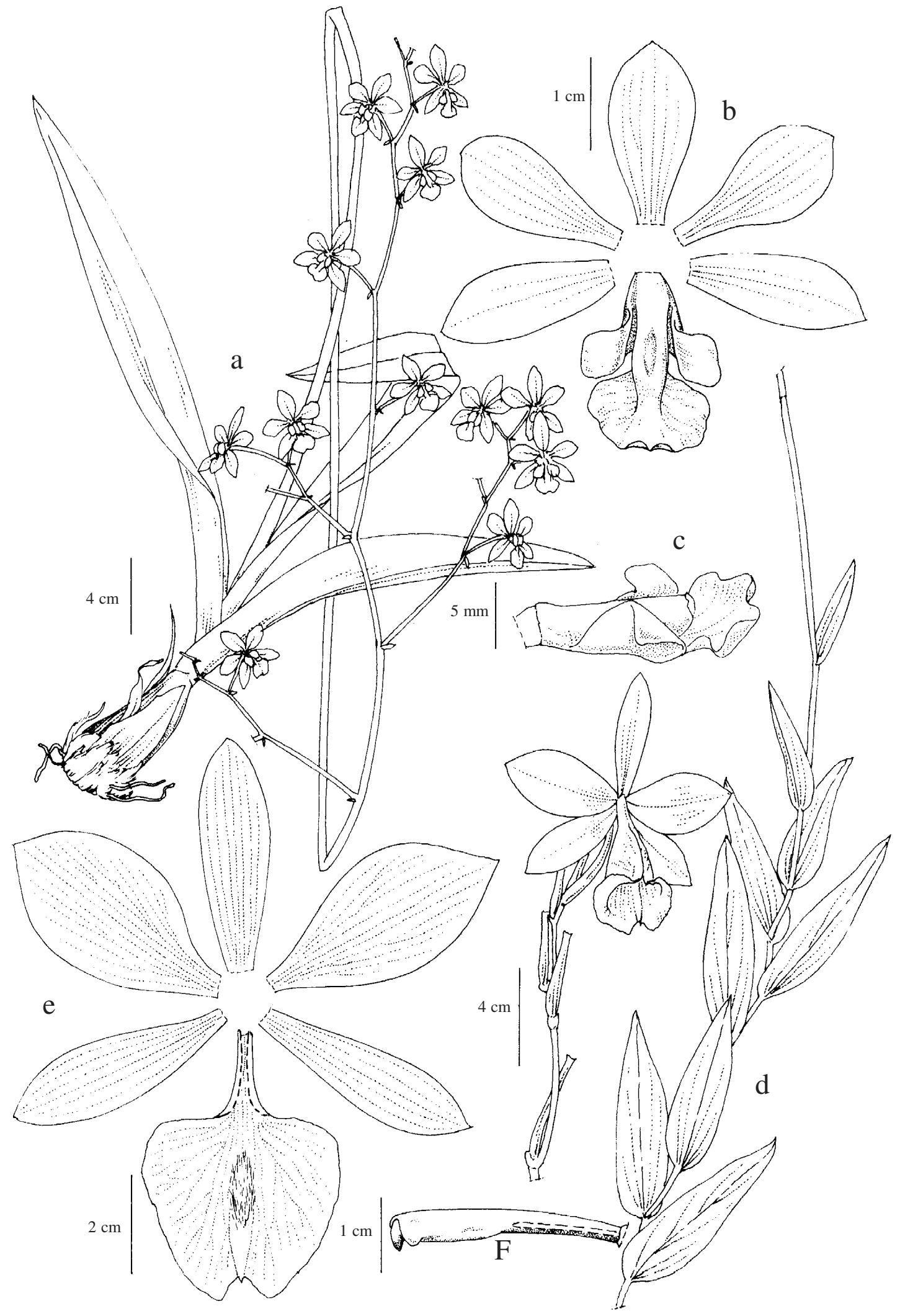

Figura 7a-c. Encyclia alboxanthina. a. Hábito. b. Diagrama floral. c. Coluna e labelo em vista lateral (C. Azevedo 159). d-f. Epistephium lucidum. d. Hábito. e. Diagrama floral. f. Coluna em vista lateral (C. Azevedo 172). 


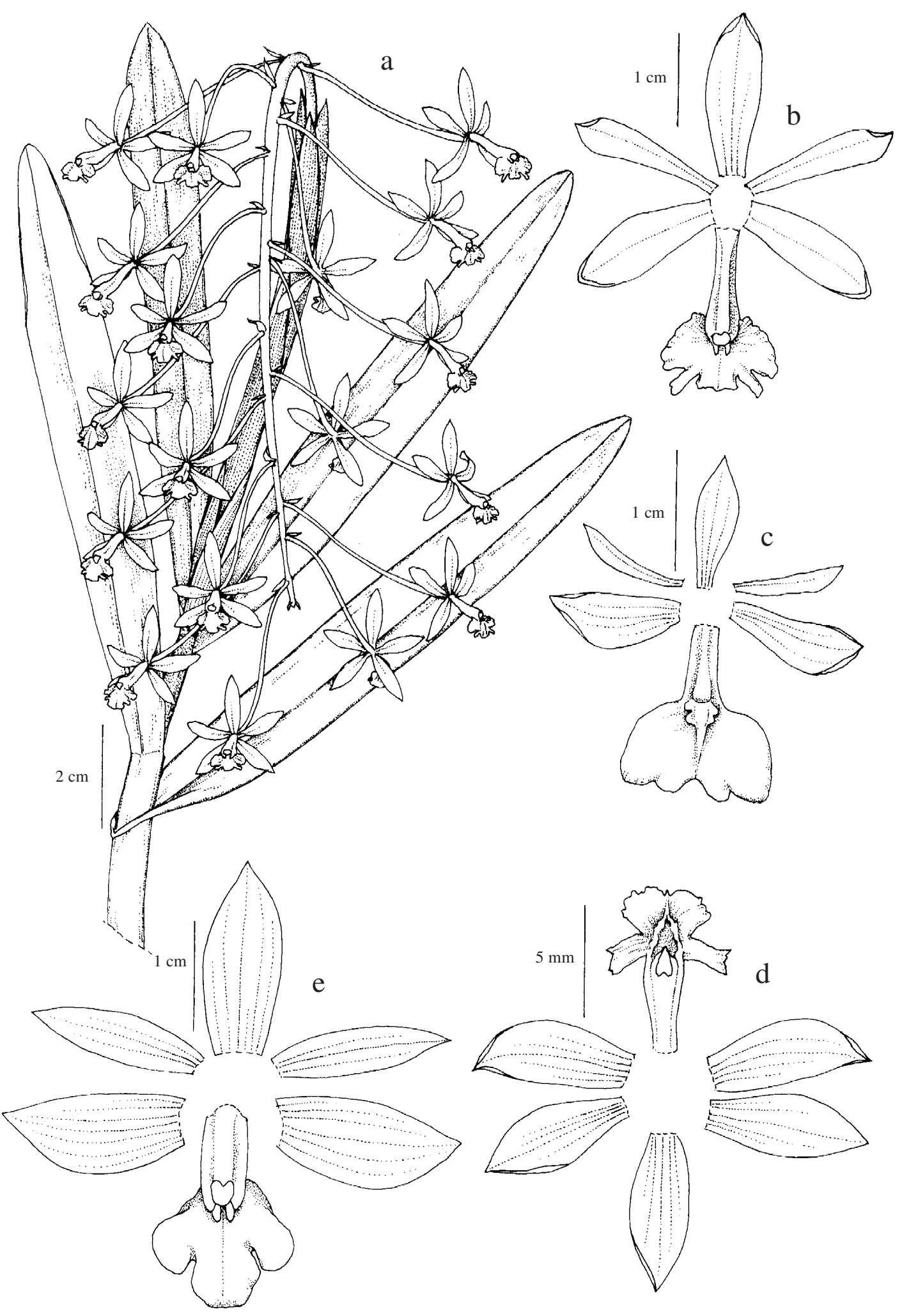

Figura 8a-b. Epidendrum cristatum. a. Hábito. b. Diagrama floral (C. Azevedo 156), Epidendrum orchidiflorum. c. Diagrama floral (C. Azevedo \& J. Oliveira 138). Epidendrum secundum. d. Diagrama floral (C. Azevedo 158). Epidendrum warasii. e. Diagrama floral (C. Azevedo \& J. Oliveira 176). 
bainhas das folhas laterais. Folhas laterais 15-20 $\times$ 3-4 mm, sésseis, sub-eretas, lanceoladas a oblongas, verdes, coriáceas, ápice retuso; folhas apicais 40-60 $\times$ 4-5 mm, sésseis, sub-eretas, oblongas, verdes, coriáceas, ápice retuso, base atenuada em pseudopecíolo. Inflorescência uniflora, lateral; pedúnculo 4-4,5 cm compr., ereto, marrom; brácteas do pedúnculo 5-8, 7-10 × 2-3 mm, oblongas, paleáceas, ápice apiculado, base amplectiva. Flores ressupinadas, pedicelo, incluindo o ovário, 10-12 mm compr.; sépalas 8-10 × 2-3 mm, eretas, esverdeadas, nuances vináceas no ápice, membranáceas, ápice agudo, a dorsal linear, as laterais triangulares; pétalas 6-7 ×1,5-2 mm, eretas, lanceoladas, esverdeadas, nuances vináceas no ápice, membranáceas, ápice agudo; labelo articulado com o pé da coluna, ereto, 3-lobado, esverdeado, nuances vináceas no ápice, calosidade amarelada, membranáceo, calo convexo, orbicular, lobos laterais 1,5 $\times$ $0,5 \mathrm{~mm}$, eretos, oblongos, ápice obtuso, lobo terminal 6-7 $\times 2-3 \mathrm{~mm}$, ereto, lanceolado, com faixa em forma de $\mathrm{V}$ coberto por substância cerosa, ápice agudo; coluna $4 \times 1 \mathrm{~mm}$, base prolongada em pé, vinácea, levemente curvada, polínias 4 .

Material examinado: 19-IX-2002, C. Azevedo \& J. Oliveira 153 (HUEFS).

Material adicional examinado: VENEZUELA. CARACAs, Korthals s.n. (W44547!).

Maxillaria notylioglossa foi descrita a partir de material proveniente de Caracas, Venezuela (Reichenbach 1854), Dunsterville \& Garay (1959) indicaram seu endemismo para este país, embora Pabst \& Dungs (1977) citem sua ocorrência para o Brasil em Minas Gerais e São Paulo. Toscano-de-Brito (1998) citou a ocorrência desta espécie para a Serra da Chapadinha, Bahia, no município de Lençóis, sendo aqui registrada pela primeira vez para o município de Mucugê. Rara na área do Parque, esta espécie é encontrada em paredões rochosos verticais e floresce entre maio e setembro.

Maxillaria cerifera foi descrita originalmente a partir de material proveniente de Petrópolis, Rio de Janeiro (Barbosa-Rodrigues 1877), foi citada também para os Estados do Espírito Santo, São Paulo, Paraná, Santa Catarina, Rio Grande do Sul e Minas Gerais (Pabst \& Dungs 1977, Sprunger et al. 1996). Pabst (1962) sinonimizou Maxillaria cerifera com Maxillaria notylioglossa justificando que com a ilustração de $M$. notylioglossa publicada por Dunsterville \& Garay (1959) tornou-se claro que
M. cerifera é sinônimo da espécie venezuelana. Embora alguns anos mais tarde Pabst \& Dungs (1977) voltaram a tratar as espécies separadamente. A análise do holótipo depositado no herbário de Reichenbach em Viena, deixa claro tratar-se de uma única espécie.

\section{Octomeria $\mathrm{R} . \mathrm{Br}$.}

Chave de identificação para as espécies de Octomeria ocorrentes no Parque Municipal de Mucugê

1. Folhas cilíndricas, verdes; flores brancas com máculas vináceas a amarelas

2. Planta 28-55 mm alt.; flores brancas, translúcidas com máculas vináceas; labelo inteiro ...... O. flabellifera

2. Planta $70-150 \mathrm{~mm}$ alt.; flores amarelas; labelo 3-lobado .......... alexandrii

1. Folhas lanceoladas, verdes a arroxeadas; flores róseas com margem alaranjada e labelo avermelhado. O. sagittata

Octomeria alexandrii Schltr., Mem. Inst. Butantan, Secc. Bot. 1 (4): 53, pl. 12. 1922.

Figuras 10a-d, 18a

Erva rupícola. Rizoma inconspícuo. Caule 40-90 × 1-2 mm, 1-foliado, ereto, cilíndrico, marrom. Folha 30-60 ×5 mm, séssil, ereta, cilíndrica, verde, carnosa, ápice agudo. Inflorescência fasciculada terminal, 1-2-flora concomitantemente em antese. Flores ressupinadas, pedicelo, incluindo o ovário, $5,0 \mathrm{~mm}$ compr.; sépalas 5-6 × 2,5-3 mm, patentes, ovadas, amarelas com ápice amarronzado, membranáceas, ápice reflexo; pétalas 5,5-6×2,5 mm, patentes, elípticolanceoladas, amarelas com ápice amarronzado, membranáceas, ápice reflexo; labelo articulado com o pé da coluna, ereto, 3-lobado, obovado, amarelo, membranáceo, calosidade provida de duas quilhas erguidas, lobos laterais 1-1,5 × 0,5-1 mm, eretos, oblongos, ápice obtuso, lobo terminal 1,5-2 ×2-2,5 mm, ereto, obovado, ápice emarginado; coluna 2-3 $\times$ 0,5-1 $\mathrm{mm}$, base prolongada em pé de 2,0 mm compr., amarelada, levemente curvada, polínias 8 .

Material examinado: 11-VI-2002, C. Azevedo \& J. Oliveira 137 (HUEFS); 13-VII-2002, C. Azevedo 145 (HUEFS).

Material adicional examinado: BRASIL, BAHIA: Serra 


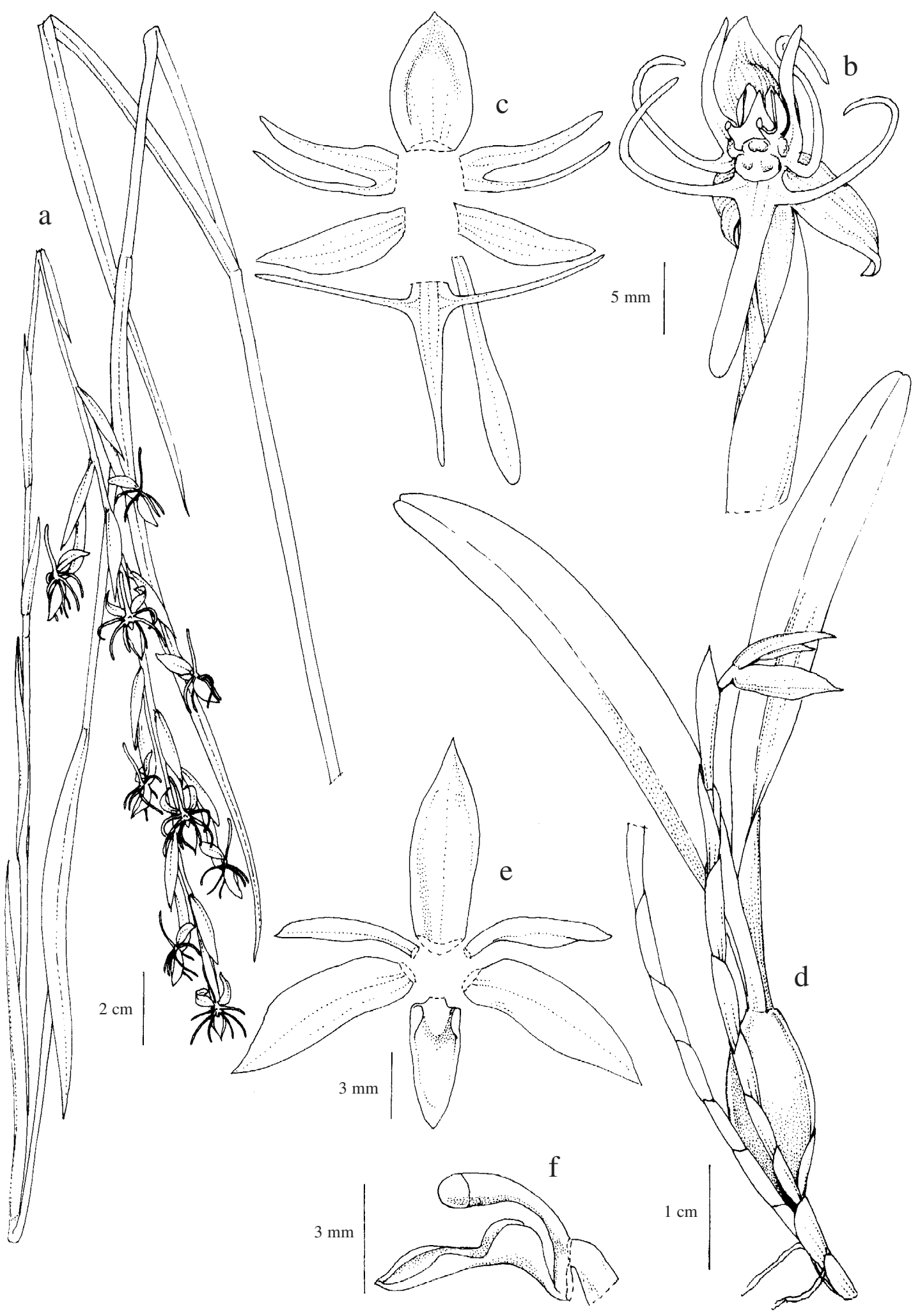

Figura 9a-c. Habenaria fluminensis. a. Hábito. b. Flor. c. Diagrama floral (C. Azevedo 141). d-f. Maxillaria notylioglossa. d. Hábito. e. Ddiagrama floral. f. Coluna e labelo em vista lateral (C. Azevedo \& J. Oliveira 153). 
do Sincorá, 27-III-1980, R.M.Harley et al. 21023 (CEPEC, K).

Restrita ao Brasil, Octomeria alexandrii, foi descrita originalmente para o Estado de São Paulo (Schlechter 1922), tendo sido citada também para o Estado do Rio de Janeiro (Pabst \& Dungs 1975). Na Bahia, foi citada para Lençóis e Palmeiras (Toscanode-Brito 1998), sendo aqui registrada pela primeira vez para o município de Mucugê. Esta espécie é comum na área do Parque, onde cresce diretamente sobre as rochas em campo rupestre, e é encontrada em flor nos meses de abril, junho e setembro.

Octomeria alexandrii caracteriza-se por apresentar folha cilíndrica, ereta e inflorescência uniflora ou, mais raramente, com duas flores simultaneamente em antese, e pela forma e coloração de suas flores, amarelas com ápice amarronzado.

Octomeria flabellifera Pabst, Bradea 2(10): 56, t. 1, fig. H. 1975.

Figuras 10e-i, 18b

Erva rupícola. Rizoma inconspícuo. Caule 13-20 × 0,5-1 mm, 1-foliado, ereto, cilíndrico, marrom. Folha 15-35 × 2-3 mm, séssil, ereta, cilíndrica, verde, coriácea, ápice agudo. Inflorescência fasciculada terminal, 1 flor em antese; brácteas florais inconspícuas. Flor ressupinada, pedicelo, incluindo o ovário, 2,5-3 mm compr.; sépalas 7-8 × 2-2,5 mm, eretas, lanceoladas, branco-translúcidas com máculas vináceas, uma maior, bem marcante na base das sépalas laterais, membranáceas, ápice agudo; as laterais adnadas na base e aderentes ao pé da coluna; pétalas 7-8 × 1,5-2 mm, eretas, lanceoladas, brancotranslúcidas com máculas vináceas, membranáceas, ápice agudo; labelo 3,5-4 × 2,5-3 mm, articulado com o pé da coluna, ereto, inteiro, transversalmente elíptico, branco-translúcido, calosidade central amarela e quilhas vináceas, membranáceo, ápice retuso, base ungüiculada, disco do labelo com calosidade central e três quilhas erguidas; coluna 2-2,5 $\times 0,5 \mathrm{~mm}$, esverdeada, polínias 8 . Fruto cápsula 8-9 $\times 2,5-3 \mathrm{~mm}$.

Material examinado: 18-IX-2002, C. Azevedo \& $R$.Oliveira 151 (HUEFS).

Originalmente descrita do Morro do Cambirela, Florianópolis, Santa Catarina (Pabst 1975), foi citada por Pabst \& Dungs (1975) apenas para aquele Estado, sendo aqui citada pela primeira vez para a Bahia. Sua distribuição está restrita ao Brasil. Planta rara no Parque, foi encontrada crescendo em paredões rochosos, apenas em áreas sombreadas de matas de grotão. Foi observada em flor nos meses de maio, setembro e outubro.

Octomeria flabellifera é facilmente reconhecida por seu labelo de base muito estreita e lâmina largamente flabelada, característica que a diferencia da outra espécie da Seção Kinetoglossum, Octomeria campos-portoi Schltr. (Pabst 1975). Diferencia-se das outras Octomeria do Parque por seu porte delicado e por apresentar flores grandes em relação à planta, além do formato de suas flores, principalmente do labelo, que é inteiro e flabeliforme. Suas flores apresentam coloração branco-translúcida com máculas vináceas, uma das quais é maior e mais marcante na base de cada sépala lateral, calosidade central amarela e quilhas vináceas.

Octomeria sagittata (Rchb.f.) Garay, Bot. Mus. Leafl. 21: 253. 1967.

Figuras 10j-m, 18C

Erva rupícola. Rizoma 1-3 mm compr. entre pseudobulbos. Caule (4,5-)11-22 × $1 \mathrm{~mm}, 1$-foliado, ereto, cilíndrico, verde a arroxeado. Folha $15-25 \times$ 4-8 mm, séssil, ereta, lanceolada, verde a arroxeada, carnosa, ápice agudo. Inflorescência fasciculada terminal, 1 flor em antese; brácteas florais inconspícuas. Flor ressupinada, pedicelo, incluindo o ovário, 1-2 mm compr.; sépalas 4-5 × 1,5-2 mm, ovadas, róseas com margem alaranjada, membranáceas, ápice agudo, a dorsal patente a ereta, as laterais patentes, adnadas na base até $1 / 3$ do comprimento; pétalas 3,5-4 × 1-1,5 mm, patentes, lanceoladas, róseas com margem alaranjada, membranáceas, ápice agudo; labelo articulado com o pé da coluna, ereto, 3-lobado, obovado, avermelhado, membranáceo, calosidade formada por duas quilhas erguidas, lóbulos laterais $0,5-1 \times 0,5 \mathrm{~mm}$, eretos, arredondados, ápice obtuso, lóbulo terminal 2,5-3 $\times$ 1-1,5 mm, ereto, obovado, ápice emarginado; coluna $1-1,5 \times 0,5 \mathrm{~mm}$, amarelada, base prolongada em pé de 0,5-1 mm compr., polínias 8 .

Material examinado: 13-VII-2002, C. Azevedo 143 (HUEFS).

Conhecida apenas para o Brasil, Octomeria sagittata, foi descrita originalmente para o Estado da Bahia, tendo sido citada apenas para este Estado por Pabst \& Dungs (1975). É aqui registrada pela primeira vez para a Chapada Diamantina. Na área do Parque, é encontrada em paredões rochosos, florindo nos 


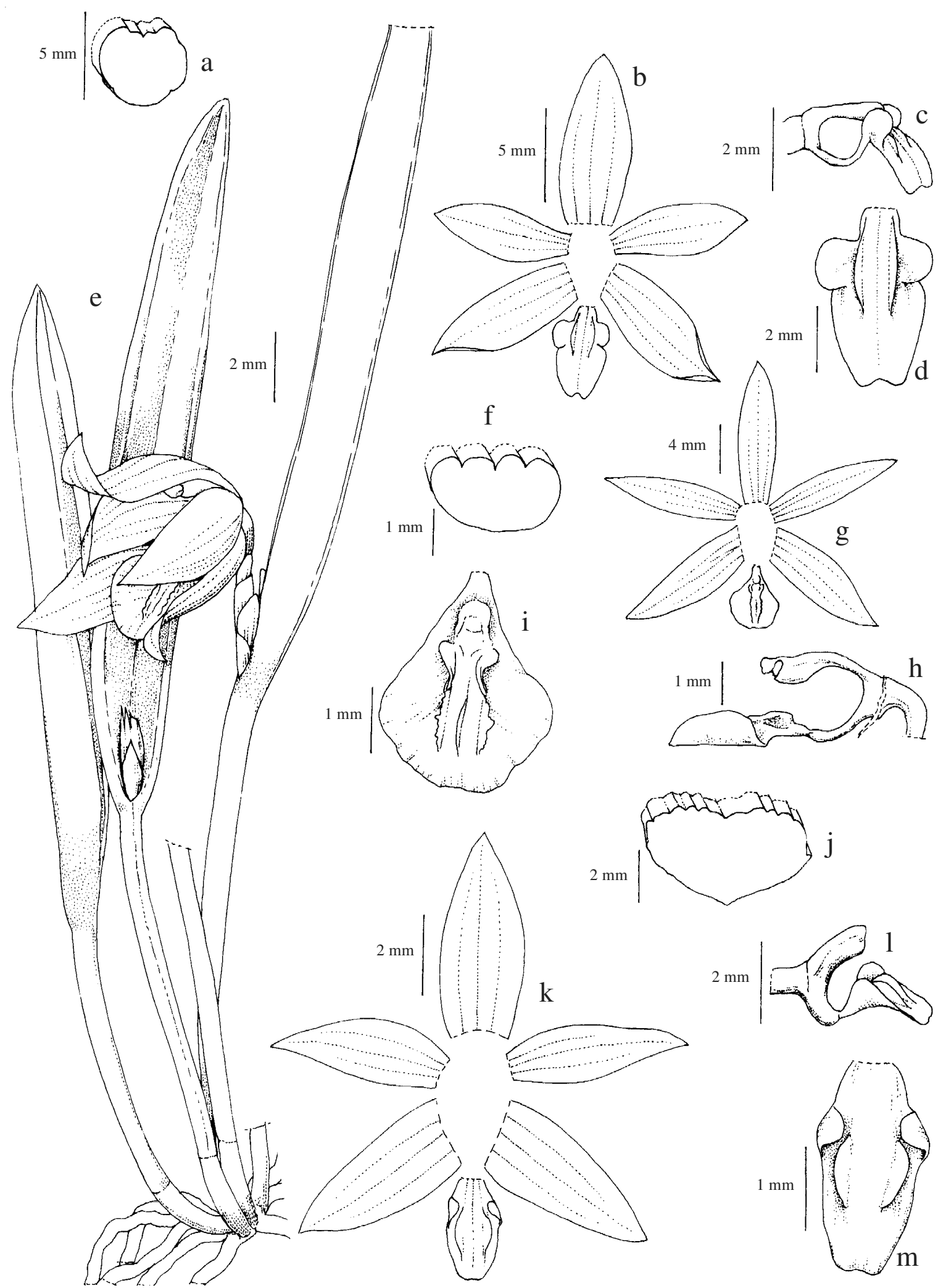

Figura 10a-d. Octomeria alexandrii. a. Folha em corte transversal. b. Diagrama floral. c. Coluna e labelo em vista lateral. d. Labelo em detalhe (C. Azevedo \& J. Oliveira 137). e-i. Octomeria flabellifera. e. Hábito. f. Folha em corte transversal. g. Diagrama floral. h. Coluna e labelo em vista lateral. i. Labelo em detalhe (C. Azevedo \& $R$. Oliveira 151). j-m. Octomeria sagittata. j. Folha em corte transversal. k. Diagrama floral. 1. Coluna e labelo em vista lateral. m. Labelo em detalhe (C. Azevedo 143). 
meses de abril, julho e setembro.

Octomeria sagittata diferencia-se das outras espécies de Octomeria pelo seu pequeno porte, por apresentar folhas lanceoladas, carnosas, e pela coloração e formas de suas flores róseas com margem alaranjada, apresentando sépalas ovadas e pétalas lanceoladas, ambas com ápice agudo, não caudado, sépalas dorsais adnadas na base, apenas até $1 / 3$ do comprimento e labelo avermelhado, com lóbulo terminal obovado de ápice obtuso emarginado.

\section{Oncidium Sw.}

Oncidium blanchetii Rchb. f., Linnaea 22: 845. 1849. Figuras 11a-b, 18d

Erva terrestre. Rizoma inconspícuo. Pseudobulbos 5-10 $\times$ 2-3 cm, 2-foliados, eretos, ovóides, amarelo-esverdeados, cobertos pelas bainhas das folhas laterais. Folhas laterais 10-15 $\times 1-2 \mathrm{~cm}$, 2-3, sésseis, sub-eretas, linear-lanceoladas, verdes, coriáceas, ápice agudo, base articulada com as bainhas $8-10 \times 1,5-2 \mathrm{~cm}$, lanceoladas, verdes; folha apical 33-35 × 1,5-2 cm, séssil, sub-ereta, linear-lanceolada, verde, coriácea, ápice agudo. Inflorescência em panícula lateral, ereta; pedúnculo $25-85 \mathrm{~cm}$ compr., verde; brácteas do pedúnculo 8-10×5-7 mm, ovadas, paleáceas, ápice agudo; raque $18-22 \mathrm{~cm}$ compr., 20-30-flora; brácteas florais 3-7 × 1-2 mm, triangulares, membranáceas, ápice agudo. Flores ressupinadas, pedicelo, incluindo o ovário, 8-10 mm compr.; sépalas amarelas com máculas marrons, membranáceas, ápice agudo, a dorsal 6-7 × 3-4 mm, ereta, ovada, côncava, as laterais 8-9 × 3,5-4 mm, reflexas, adnadas na base até a metade, lanceoladas; pétalas 6-7 ×4-5 mm, reflexas, orbiculares, amarelas com máculas marrons, membranáceas, ápice obtuso; labelo patente, 3-lobado, orbicular, amarelo com máculas marrons no calo e na face adaxial, membranáceo, calo formado de quilhas centrais curtas e elevadas e por verrugas laterais, lobos laterais 4,5-5 × 1,5-2,5 mm, patentes, oblongos, ápice obtuso, lobo terminal 7-11 $\times 15-18 \mathrm{~mm}$, patente, orbicular, ápice emarginado; coluna 3,5-5 ×2-2,5 mm, marrom, tábula infrastigmática amarela, polínias 2.

Material examinado: 11-VI-2002, C. Azevedo \& J. Oliveira 135 (HUEFS).

Materiais adicionais examinados: BRASIL. BAHIA: Mucugê, Serra do Capa Bode, IX-1973, G.C.P. Pinto s.n. (ALCB 9076); Guiné, 19-XI-2002, E.C. Smidt 274 (HUEFS).
Pabst \& Dungs (1977) indicaram a ocorrência desta espécie para a Bolívia e Brasil, para Pernambuco, Bahia, Rio de Janeiro, São Paulo, Paraná, Santa Catarina e Minas Gerais. Na Bahia foi citada para a Serra do Ouro - Barra da Estiva/Ituaçú (Harley \& Mayo 1980) e para os municípios de Rio de Contas, identificada como Oncidium ramosum Lindl. (Toscano-de-Brito 1995), Lençóis (Toscano-de-Brito 1998), Palmeiras (Toscano-de-Brito 1998, Conceição \& Giulietti 2002) e Catolés (Toscano-de-Brito \& Queiroz 2003). Silva (1999) cita sua ocorrência para Abaíra, Andaraí, Barra da Estiva, Ibicoara, Lençóis, Mucugê, Palmeiras, Rio de Contas, Seabra e Jacobina. Cresce geralmente em solos rasos, entre as rochas dos campos rupestres, florescendo entre junho e julho.

Oncidium blanchetii possui morfologia floral bastante variável, principalmente no formato do labelo, dos lóbulos laterais e verrugas laterais do calo central, as quais podem estar ausentes ou presentes em diferentes indivíduos e em número variável (Silva 1999). As sépalas e pétalas também variam em forma e coloração. Pabst \& Dungs (1977) apresentaram três ilustrações desta espécie, que mostram as variações que ela pode apresentar. Assemelha-se a Oncidium hydrophilum Barb. Rodr., embora este último apresente flores maiores e inflorescência em racemo.

\section{Polystachya Hook.}

Polystachya micrantha Schltr., Repert. Spec. Nov. Regni Veg. 35: 81. 1925.

Figura 11c-e, 18e

Erva rupícola. Rizoma inconspícuo. Pseudobulbos 10-20 × 5-10 mm, eretos, ovóides, verdes, cobertos pelas bainhas das folhas. Folhas $2-10 \times 0,5-1,5 \mathrm{~cm}$, sésseis, sub-eretas, oblongas, verdes, coriáceas, ápice obtuso. Inflorescência em panícula terminal, ereta; pedúnculo 7-10 cm compr., verde; brácteas do pedúnculo 40-64 × 4-5,5 mm, oblongas, paleáceas, ápice agudo, base amplectiva; raque $44-90 \mathrm{~mm}$ compr., ciliada, 3-12-flora; brácteas florais 2,5-4 × 1-1,5 mm, ovadas a triangulares, membranáceas, ápice agudo. Flores não ressupinadas, pedicelo, incluindo o ovário, 3-4 mm compr.; sépalas ereto-patentes, amarelo-esverdeadas, membranáceas, ápice acuminado, a dorsal 2,5-3 $\times 1,5-2 \mathrm{~mm}$, ovada, as laterais 3-3,5 $\times 2$-2,5 mm, ovado-orbiculares; pétalas 2-2,5 $\times 0,5-1 \mathrm{~mm}$, ereto-patentes, linear-lanceoladas, amarelo-esverdeadas, membranáceas, ápice obtuso; labelo ereto, 3-lobado, amarelo-esverdeado, membranáceo, calosidade em forma de quilha erguida no 
centro do labelo, lobos laterais 1-1,5 × 0,5-1 mm, erguidos, orbiculares, ápice obtuso, lobo terminal 2,5-3 $\times 1,5-2 \mathrm{~mm}$, ereto, oblongo, ápice reflexo, porção central da face adaxial coberto por tricomas; coluna 1-1,5 × 1-1,5 mm, amarelo-esverdeada, polínias 2 .

Materiais examinados: 18-III-2003, C. Azevedo \& J.Oliveira 181 (HUEFS); 13-IV-2003, C. Azevedo 189 (HUEFS); Unidade de Manejo Sustentável, 1-XI-1996, UMS 344 (HRB).

Espécie brasileira, citada por Pabst \& Dungs (1975) para São Paulo e Rio Grande do Sul, sendo aqui registrada pela primeira vez para o Estado da Bahia. Cresce diretamente sobre as rochas do campo rupestre. Foi encontrada florida entre março e abril, e em novembro.

Polystachya micrantha apresenta flores não ressupinadas, o que a diferencia de grande parte das espécies do Parque. Possui labelo trilobado, amareloesverdeado e calosidade em forma de quilha erguida no centro do labelo.

\section{Prescottia Lindl.}

Chave de identificação para as espécies de Prescottia ocorrentes no Parque Municipal de Mucugê

1. Inflorescência congesta, cônica; raque ca. $6 \mathrm{~cm}$ compr. P. montana

1. Inflorescência laxa; raque $8-24 \mathrm{~cm}$ compr.

2. Folhas verde-prateadas com margem inteira; labelo com ápice

obtuso, levemente emarginado P. leptostachya

2. Folhas verdes com lista branca na margem, margem ligeiramente serrilhada; labelo com ápice agudo P. stachyodes

Prescottia leptostachya Lindl., Bot. Reg. 22:sub t. 1916. 1836.

Figura 12a-c

Erva terrestre. Raízes carnosas. Caule inconspícuo. Folhas 2-3 basais em roseta, 4-5,5 $\times$ 2-2,5 cm, patentes, lanceoladas, verde-prateadas, membranáceas, ápice agudo; pecíolo 1,5-2 cm compr. Inflorescência em racemo terminal, ereta; pedúnculo 22-28 cm compr., verde; brácteas do pedúnculo 5-15 × $2 \mathrm{~mm}$, ovadas a lanceoladas, membranáceas, ápice agudo, base amplectiva; raque $8-20 \mathrm{~cm}$ compr., 35-40-flora; brácteas florais inconspícuas, triangulares, membranáceas, ápice agudo. Flores não ressupinadas, pedicelo, incluindo o ovário, 3-4 mm compr.; sépalas ovadas, verdes, membranáceas, ápice obtuso, a dorsal 2-2,5 × 0,5-1 mm, convoluta, as laterais 3-3,5 $\times$ 0,5-1 mm, reflexas, adnadas na base; pétalas 2-2,5 $\times$ $0,3 \mathrm{~mm}$, convolutas, lineares, verdes, membranáceas, ápice obtuso; labelo 3-3,5 × 1,5-2 mm, ereto, cuculado, verde, membranáceo, ápice obtuso, levemente emarginado, margem involuta, internamente glabro, base bi-auriculada ca. $1 \mathrm{~mm}$ compr.; coluna $1 \times$ 0,6 mm, verde, polínias 4 .

Material examinado: 26-XI-2002, C. Azevedo \& $R$. Oliveira 164 (HUEFS).

Descrita originalmente a partir de espécime proveniente do Estado da Bahia (Lindley 1836b), e conhecida também para o Rio de Janeiro (Hoehne 1945, Pabst \& Dungs 1975). Esta espécie tem distribuição restrita ao Brasil. Na Chapada Diamantina, foi citada para Rio de Contas (Toscanode-Brito 1995), Lençóis (Toscano-de-Brito 1998) e Catolés (Toscano-de-Brito \& Queiroz 2003), sendo aqui registrada pela primeira vez para o município de Mucugê. Cresce sobre matéria orgânica acumulada sobre as rochas em matas de grotão. Floresce em novembro.

Prescottia leptostachya é caracterizada por apresentar folhas de coloração verde-prateada de margem inteira, inflorescência alongada com raque de 8-20 cm compr., flores diminutas e labelo de ápice obtuso levemente emarginado.

Prescottia montana Barb. Rodr., Gen. Spec. Orchid. 1:178, t.485. 1877. TIPO: BRASIL, Barbosa Rodrigues s.n. (perdido). Lectótipo: ilustração original preparada por João Barbosa Rodrigues, t.485, que consta de sua Iconographie des orchidées du Brésil, depositada na biblioteca do Jardim Botânico do Rio de Janeiro, reproduzida por Sprunger et al. (1996) sob o número t.89 do volume 2 , aqui designado.

Figura 12d, e, $18 f$

Erva terrestre. Raízes carnosas, pilosas. Caule inconspícuo. Folha 1, basal, 10-11 × 1,5-2 cm, subereta, lanceolada, verde, membranácea, ápice agudo; pecíolo 8-9 $\mathrm{cm}$ compr. Inflorescência em racemo terminal, congesto, cônico, ereto; pedúnculo $45-50 \mathrm{~cm}$ compr., verde; brácteas do pedúnculo 15-40×4-6 mm, 


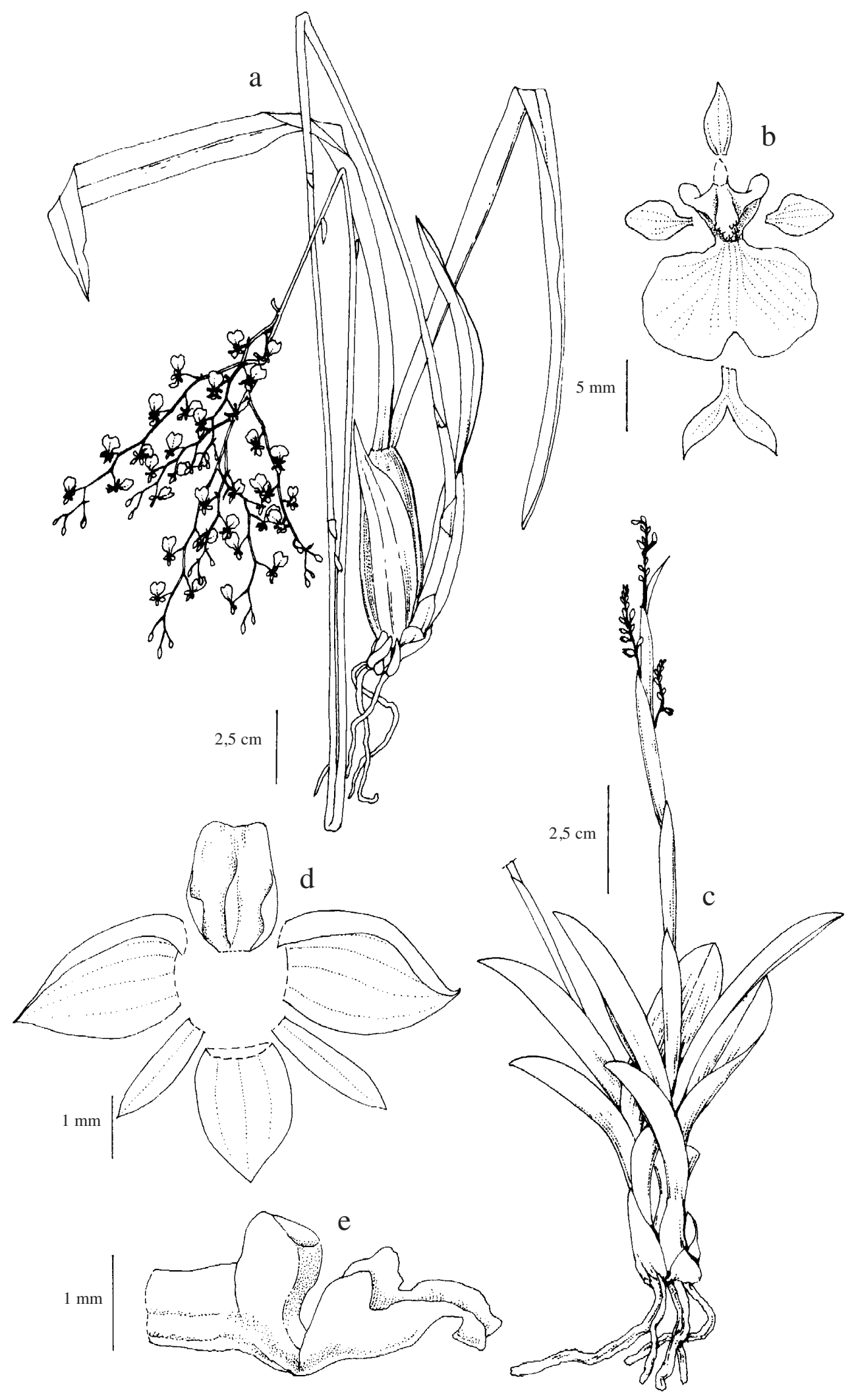

Figura 11 a-b. Oncidium blanchetii. a. Hábito. b. Diagrama floral (C. Azevedo \& J. Oliveira 135). c-e. Polystachya micrantha. c. Hábito. d. Diagrama floral. e. Coluna e labelo em vista lateral (C. Azevedo \& J. Oliveira 181). 
orbiculares, membranáceas, ápice caudado, base amplectiva; raque ca. $6 \mathrm{~cm}$ compr., 30-35-flora; brácteas florais $7-9 \times 2 \mathrm{~mm}$, orbiculares a lanceoladas, membranáceas, ápice caudado. Flores não ressupinadas, pedicelo, incluindo o ovário, $3,5 \mathrm{~mm}$ compr.; sépalas eretas, amarelo-esverdeadas, membranáceas, a dorsal 3-3,5 × 1,5 mm, ovada, ápice obtuso, as laterais 4-4,5 × 1,5 mm, adnadas na base, lanceoladas, ápice agudo; pétalas 3-3,5×1 mm, eretas, lineares, amarelo-esverdeadas, membranáceas, ápice obtuso; labelo 4-4,5 $\times 3 \mathrm{~mm}$, ereto, cuculado, verde, membranáceo, ápice obtuso, margem involuta, internamente glabro, base bi-auriculada ca. $0,5 \mathrm{~mm}$ compr.; coluna 1,5 ×1,5 mm, verde, polínias 4 .

Material examinado: 16-XII-2002, C. Azevedo \& J. Oliveira 192 (HUEFS).

Descrita originalmente para Pedra Branca, Caldas, Minas Gerais (Barbosa-Rodrigues 1877), esta espécie brasileira é citada para os Estados do Rio de Janeiro, São Paulo, Minas Gerais (Hoehne 1945, Pabst \& Dungs 1975, Sprunger et al. 1996), Espírito Santo, Paraná e Santa Catarina (Pabst \& Dungs 1975, Sprunger et al. 1996), sendo aqui registrada pela primeira vez para o Estado da Bahia. Em Minas Gerais é conhecida para a Serra do Cipó (Barros 1987) e Grão-Mogol (Barros \& Pinheiro 2004). No Parque, cresce em área fechada de mata, sobre a serrapilheira, é menos comum na área que as outras duas espécies. Foi encontrada em flor em dezembro.

Prescottia montana é facilmente reconhecida por sua inflorescência congesta, de forma cônica, por apresentar apenas uma folha e flores amareloesverdeadas. Uma lista de sinônimos é fornecida por Sprunger et al. (1996).

Prescottia stachyodes (Sw.) Lindl., Bot. Reg. 22: t. 1916. 1836. Cranichis stachyodes Sw., Prodr.: 120. 1788.

Figuras 12f-g, 18g, h

Erva terrestre. Raízes carnosas, pilosas. Caule inconspícuo. Folhas 2-3, basais em roseta, (4,5-)8-11 $\times$ 2-4 cm, sub-eretas, lanceoladas, verdes com listas brancas na margem, membranáceas, ápice agudo, margem ligeiramente serrilhada; pecíolo 2-4 cm compr. Inflorescência em racemo terminal, ereta; pedúnculo 36-63 cm compr., verde; brácteas do pedúnculo 20-50 × 5-10 mm, oblongas, membranáceas, ápice agudo, base amplectiva; raque 15-24 cm compr., 40-50-flora; brácteas florais $6-7 \times 2-2,5 \mathrm{~mm}$, lanceoladas, membranáceas, ápice caudado. Flores não ressupinadas, pedicelo, incluindo o ovário, 6-6,5 mm compr.; sépalas convolutas, ovadas, verdes, membranáceas, ápice agudo, a dorsal 3-3,5 × 1,0 mm, as laterais 6-6,5 × 1,5 mm, adnadas na base; pétalas 3-3,5 × $1 \mathrm{~mm}$, convolutas, lineares, verdes, membranáceas, ápice agudo; labelo 5-5,5 × 2,5-3 mm, ereto, cuculado, verde, membranáceo, ápice agudo, margem involuta, internamente glabro, base bi-auriculada ca. $1 \mathrm{~mm}$ compr.; coluna $2 \times 1,5 \mathrm{~mm}$, verde, polínias 4 .

Material examinado: 16-VIII-2002, C. Azevedo \& J. Oliveira 148 (HUEFS).

Esta espécie foi citada desde o México até o Panamá, Venezuela, Colômbia, Equador, Peru, Brasil (Dunsterville \& Garay 1959, Pabst \& Dungs 1975, Sprunger et al. 1996), Guianas e Índias Ocidentais (Dunsterville \& Garay 1959). No Brasil, é citada para os Estados do Pará, Bahia, Espírito Santo, Rio de Janeiro, São Paulo, Paraná, Santa Catarina, Rio Grande do Sul e Minas Gerais e para o Distrito Federal (Pabst \& Dungs 1975, Sprunger et al. 1996). É aqui registrada pela primeira vez para a Chapada Diamantina. Na Cadeia do Espinhaço já era conhecida da Serra do Cipó (Barros 1987). Ocorre no Parque apenas em área fechada, bastante sombreada, crescendo na serrapilheira, e floresce em agosto.

Prescottia stachyodes apresenta folhas verdes de margem branca e ligeiramente serrilhada, inflorescência alongada com raque de $15-24 \mathrm{~cm}$ compr. e labelo de ápice agudo. As folhas de Prescottia são muito variáveis em seu formato e dimensões, em função do ambiente em que as plantas crescem. Plantas que vegetam sobre rochas diferem muito daquelas que habitam o solo, o que é bastante notável em Prescottia stachyodes (Hoehne 1945), motivo pelo qual existem tantos sinônimos para algumas espécies do gênero. Sprunger et al. (1996) apresentam uma lista de sinônimos.

Prosthechea Knowles \& Westc.

Prosthechea moojenii (Pabst) W.E. Higgins, Phytologia 82(5): 379. 1998. Encyclia moojenii (Pabst) Pabst, Orquídea (Rio de Janeiro) 29(6): 276. 1967.

Figuras 13a-d, 18i

Erva rupícola. Rizoma 10-25 mm compr. entre pseudobulbos. Pseudobulbos 4,5-5 × 1,5-2 cm, 1-2-foliados, eretos, ovóides, verdes, coberto por bainhas. Folhas 12-14 × 1,5-2 cm, sésseis, sub-eretas, 


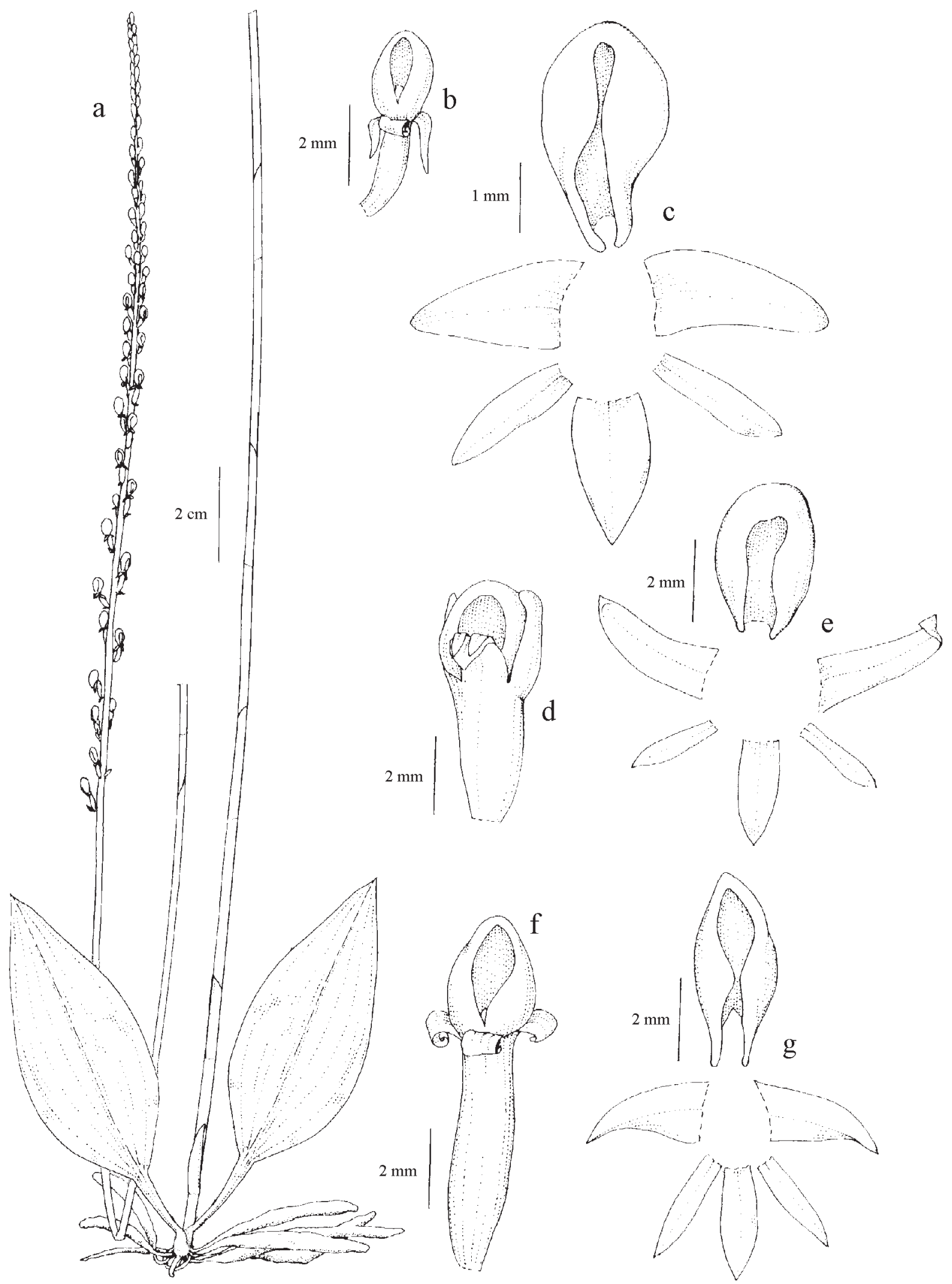

Figura 12a-c. Prescottia leptostachya. a. Hábito. b. Flor. c. Diagrama floral (C. Azevedo \& R. Oliveira 164). d-e. Prescottia montana. d. Flor. e. Diagrama floral (C. Azevedo \& J. Oliveira 192). f-g. Prescottia stachyodes. f. Flor. g. Diagrama floral (C. Azevedo \& J. Oliveira 148). 
lanceoladas a oblongas, verdes, coriáceas, ápice agudo. Inflorescência em racemo terminal, pendente, espata 10-15 × $10 \mathrm{~mm}$, ovada, ápice agudo, base amplectiva; pedúnculo 40-60 mm compr., verde; brácteas do pedúnculo inconspícuas; raque 7-8 cm compr., 4-6-flora; brácteas florais inconspícuas. Flores não ressupinadas, pedicelo, incluindo o ovário, $8-11 \mathrm{~mm}$ compr.; sépalas $15-20 \times 5 \mathrm{~mm}$, patentes, amareloesverdeadas, carnosas, ápice agudo, a dorsal lanceolada, as laterais oblongas; pétalas $12-15 \times 5 \mathrm{~mm}$, patentes, lanceoladas, amarelo-esverdeadas, carnosas, ápice agudo; labelo $12-15 \times 6 \mathrm{~mm}$, parcialmente coalescente à base da coluna, ereto, inteiro, ovado, branco podendo apresentar linhas purpúreas, carnoso, ápice agudo; coluna 7-8 × 4-5 mm, amareloesverdeada, polínias 4.

Materiais examinados: 26-XI-2002, C. Azevedo \& J. Oliveira 163 (HUEFS); 26-XI-2002, C. Azevedo \& R.Oliveira 166 (HUEFS).

Endêmica da Cadeia do Espinhaço, esta espécie é citada para os Estados da Bahia e Minas Gerais (Pabst \& Dungs 1975), tendo sido descrita a partir de material da Chapada Diamantina, entre Lençóis e Palmeiras (Pabst 1955). É aqui registrada pela primeira vez para o município de Mucugê, onde cresce em paredões rochosos. Floresce em novembro.

Pabst (1955) provavelmente se enganou quanto à localização desta espécie, referindo-se ao local de coleta como município de Castro Alves, que fica na região do Recôncavo Sul da Bahia, ao mesmo tempo em que afirma ter sido entre os municípios de Lençóis e Palmeiras, que estão localizados na região da Chapada Diamantina no mesmo Estado. Prosthechea moojenii apresenta flores não ressupinadas, amareloesverdeadas, labelo branco, com ou sem linhas longitudinais purpúreas, inteiro, parcialmente coalescente à base da coluna.

Scaphyglottis Poepp. \& Endl.

Scaphyglottis modesta (Rchb.f.) Schltr., Repert. Spec. Nov. Regni Veg. 23: 46. 1926. Tetragamestus modestus Rchb.f., Bonplandia 2: 21. 1854.

Figura 14a-b

Erva rupícola. Rizoma inconspícuo. Pseudobulbos 30-90 × 2-3 mm, 2-foliados, eretos, cilíndricos, verdes, sobrepostos, emergindo do ápice do pseudobulbo anterior. Folhas 40-80 × 7-12 mm, sésseis, sub-eretas, lanceoladas a oblongas, verdes, coriáceas, ápice obtuso. Inflorescência fasciculada terminal. Flores não observadas, apenas restos florais; sépalas 4-5 $\times$ 2-2,5 mm, ápice agudo, a dorsal elíptica, as laterais ovada; pétalas $4-5 \times 1,5 \mathrm{~mm}$, lanceoladas, ápice agudo; labelo $5 \times 2 \mathrm{~mm}$, ereto, discretamente 3-lobado, oblongo, calo bilobado, lobos laterais auriculares, ápice obtuso, lobo terminal orbicular, ápice obtuso; coluna $4 \times 1,5 \mathrm{~mm}$, base prolongada em pé de $2 \mathrm{~mm}$ compr., polínias 4. Fruto cápsula 8-10 × 3-5 mm.

Material examinado: 19-X-2002, C. Azevedo \& R. Oliveira 160 (HUEFS).

O tipo de Tetragamestus modestus tem origem desconhecida (Reichenbach 1854). Esta espécie foi citada para a Guiana, Venezuela, Caribe, Trindade, e no Brasil, para os Estados do Espírito Santo, Rio de Janeiro, São Paulo, Paraná, Santa Catarina, Rio Grande do Sul e Minas Gerais (Pabst \& Dungs 1975), sendo aqui registrada pela primeira vez para a Bahia. Rara no Parque, cresce somente em áreas de matas de grotão, em paredões rochosos.

O material examinado não foi encontrado em flor, mas sua identificação foi feita através da análise da porção vegetativa e dos restos florais persistentes no fruto. Scaphyglottis modesta pode ser facilmente diferenciada das outras espécies do Parque por apresentar pseudobulbos sobrepostos, ou seja, os novos pseudobulbos crescem também do ápice do pseudobulbo antigo.

Neste trabalho, seguimos a revisão de Adams (1993), que inclui o gênero Tetragamestus em Scaphyglottis, posição confirmada por dados moleculares (Dressler \& Whitten 2004). Adams (1993) propôs duas subespécies: Scaphyglottis modesta subsp. modesta com plantas mais delgadas, folhas até 12-16 mm larg., flores bastante abertas, sépala dorsal 5,5-6 mm compr., labelo com calo proeminente bilobado, e Scaphyglottis modesta subsp. striolata, que se caracteriza por apresentar plantas robustas, folhas com 12-23 mm larg., flores pouco abertas, aparentemente cleistógamas, sépala dorsal com 4-5,5 mm compr., labelo com calo indistintamente bilobado ou somente carnoso entre os lobos laterais. As subespécies apresentam distribuição geográfica distinta, Scaphyglottis modesta subsp. modesta ocorrendo no Suriname e sudeste do Brasil e S. modesta subsp. striolata ocorrendo nas Índias Ocidentais e na América do Sul, desde as Guianas até o norte do Brasil e Equador. O material aqui estudado apresenta caracteres intermediários entre as duas subespécies, assemelhando-se a 
Scaphyglottis modesta subsp. modesta por apresentar folhas com 7-12 mm larg. e labelo com calo bilobado, embora apresente sépala dorsal com 4-5 $\mathrm{mm}$ compr. e grande número de frutos, o que pode ser resultante de cleistogamia, o que é comum em $S$. modesta subsp. striolata. Uma conclusão definitiva sobre as afinidades infraspecíficas do material do Parque não pode ser obtida até que se tenha material com flores e se estude uma amostragem mais ampla desta espécie, e seus tipos.

Sobralia Ruiz \& Pav.

Sobralia sessilis Lindl., Bot. Reg. (misc.): 3. t. 17. 1841. Figuras $14 \mathrm{c}-\mathrm{d}, 18 \mathrm{j}$

Erva rupícola. Rizoma inconspícuo, raízes espessas. Caule 100-150 ×0,5-1 cm, ereto, cilíndrico, verde, coberto pelas bainhas das folhas, 6-7-foliado.

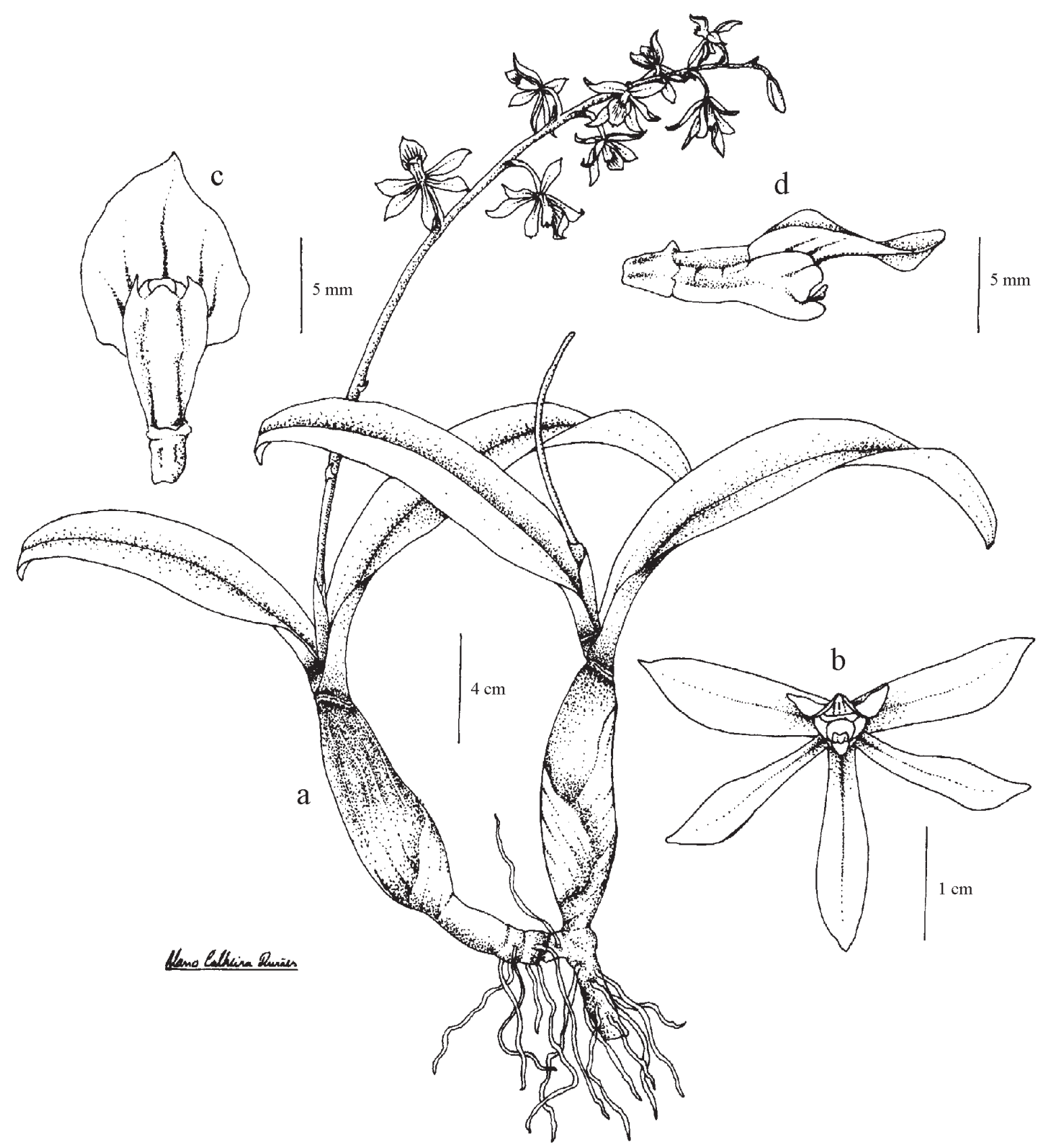

Figura 13. Prosthechea moojenii. a. Hábito. b. Flor. c. Coluna e labelo em vista frontal. d. Coluna e labelo em vista lateral (C. Azevedo \& J. Oliveira 163). 
Folhas 7-12 × 1,5-2,5 cm, dísticas, sésseis, plicadas, sub-eretas, oblongo-lanceoladas, verdes, coriáceas, ápice acuminado. Inflorescência em racemo terminal, bráctea do pedúnculo $28-38 \times 2,5-4,5 \mathrm{~mm}$, imbricadas, paleáceas, purpúreas, ápice agudo; 1-2-flora concomitantemente em antese. Flores ressupinadas, pedicelo, incluindo o ovário, 26-37 mm compr.; sépalas patentes, lanceoladas, purpúreas, membranáceas, ápice apiculado, reflexo, a dorsal $45-46 \times 12-14 \mathrm{~mm}$, as laterais $45-50 \times 13-15 \mathrm{~mm}$; pétalas 40-45 × 14-15 mm, patentes, lanceoladas, purpúreas, membranáceas, ápice reflexo; labelo 40-45 × 25-27 mm, ereto, inteiro, obovado, purpúreo, membranáceo, ápice retuso, margem ondulada, base com 2 calos; coluna 22-24 $\times$ 3,5-4,0 mm, branca, com 2 braços voltados para frente, polínias 4. Fruto cápsula 70-75 × 15-20 mm, verde.

Materiais examinados: 11-VI-2002, C. Azevedo \& J. Oliveira 136 (HUEFS); 16-XII-2002, C. Azevedo \& J. Oliveira 171 (HUEFS); 20-II-2003, C. Azevedo \& J. Oliveira 180 (HUEFS).

Esta espécie é citada para a Venezuela, Colômbia, Peru, Guianas e Brasil (Hoehne 1945, Sprunger 1991), e, neste último, desde o Pará até Minas Gerais (Hoehne 1945). Pabst \& Dungs (1975) também citaram sua ocorrência para os Estados do Amazonas, Roraima, Acre, Amapá, Pará e Minas Gerais. Na Bahia, Harley \& Mayo (1980) indicaram sua presença no Morro do Chapéu, sendo aqui registrada pela primeira vez para o município de Mucugê. Cresce sobre matéria orgânica que se acumula nas rochas do campo rupestre, formando densas touceiras. Foi encontrada em flor nos meses de fevereiro, maio, junho e dezembro.

No Parque, Sobralia sessilis é reconhecida por suas folhas plicadas, brácteas imbricadas e grandes flores purpúreas, porém bastante efêmeras, murchando em aproximadamente 24 horas. Outra espécie do gênero, Sobralia liliastrum Lindl., embora não tenha sido encontrada na área do Parque, é comum não só no município de Mucugê, como em toda a Chapada Diamantina, em afloramentos rochosos e na restinga. É facilmente distinguível de Sobralia sessilis por apresentar folhas mais estreitas, inflorescências com brácteas em zig-zag, não imbricadas e flores brancas com centro do labelo amarelo.

\section{Sophronitis Lindl.}

Sophronitis bahiensis (Schltr.) Van den Berg \& M.W. Chase, Lindleyana 15(2): 116. 2000. Laelia bahiensis Schltr., Repert. Spec. Nov. Regni Veg. 17: 272. 1921.
Figuras 15a-b, 18k

Erva rupícola. Rizoma inconspícuo. Pseudobulbos 4-6 × 1,5-2 cm, 1-foliados, eretos, estreitamente ovóides, verdes a arroxeados. Folha 10-11 x 1,5-2,5 cm, séssil, sub-ereta a ereta, oblonga a lanceolada, verde a arroxeada, coriácea, ápice obtuso. Inflorescência em racemo terminal, ereto, espata 40-75 × 10-20 mm, ovada a oblonga, ápice agudo, base amplectiva; pedúnculo $42-80$ cm compr.; brácteas do pedúnculo $5,-10 \times 5-9 \mathrm{~mm}$, ovadas a orbiculares, paleáceas, ápice aculeado, base amplectiva; raque 10-15 cm compr., 4-8-flora; brácteas florais 3-6 $\times$ 1-2 mm, triangulares a ovadas, membranáceas, ápice agudo. Flores ressupinadas, pedicelo, incluindo o ovário, 25-40 mm compr.; sépalas 18-20 × 4-5 mm, patentes, oblongo-lanceoladas, amarelas a laranjas, membranáceas, ápice apiculado, reflexo; pétalas 18-20 × 4-6 mm, patentes, obtusas, amarelas a laranjas, membranáceas, ápice reflexo; labelo ereto, 3-lobado, obovado, amarelo a laranja, membranáceo, disco com 4 pequenas quilhas centrais, aproximadamente até o meio do labelo, lobos laterais 5-6 × 3-4 mm, eretos envolvendo a coluna, obtusos, ápice obtuso, lobo terminal 7-9 $\times$ 5-6 mm, obovado, ápice agudo, ungüiculado, reflexo, margem ondulada; coluna 7-9 $\times$ 3-4 mm, levemente curvada, polínias 8 .

Materiais examinados: 19-IX-2002, C. Azevedo \& E. Ribeiro 154 (HUEFS); 19-X-2002, C. Azevedo 161 (HUEFS).

Materiais adicionais examinados: BRASIL. BAHIA: estrada entre Andaraí e Mucugê, 20-XI-1983, L.R. Noblick \& A. Pinto 2884 (CEPEC); Serra do Sincorá, XI-1906, E. Ule 7094 (K); Mucugê, estrada MucugêGuiné, 7-IX-1981, CFCR 2060 (K, SPF); a 7 km de Mucugê em direção a Andaraí, 17-XI-1983, H.P. Bautista 1418 (HRB, HUEFS); Serra do Capa Bode, XI-1973, G.C.P. Pinto s.n (ALCB 633, HRB 31062).

Descrita originalmente de material procedente da Bahia (Schlechter 1921), Pabst \& Dungs (1975) também citaram sua presença no Estado. Sophronitis bahiensis foi descrita como sendo epífita, a partir de um espécime coletado pelo Dr. Philipp von Luetzelburg, sem localidade. Luetzelburg indicou, em Estudo Botânico do Nordeste, a correta localização como Serra do São José, próximo a Feira de Santana. Luetzelburg provavelmente se enganou quanto à procedência desta espécie, pois esta planta não foi mais coletada nesta serra, sendo encontrada apenas na Chapada Diamantina. Em 1968, ela foi 


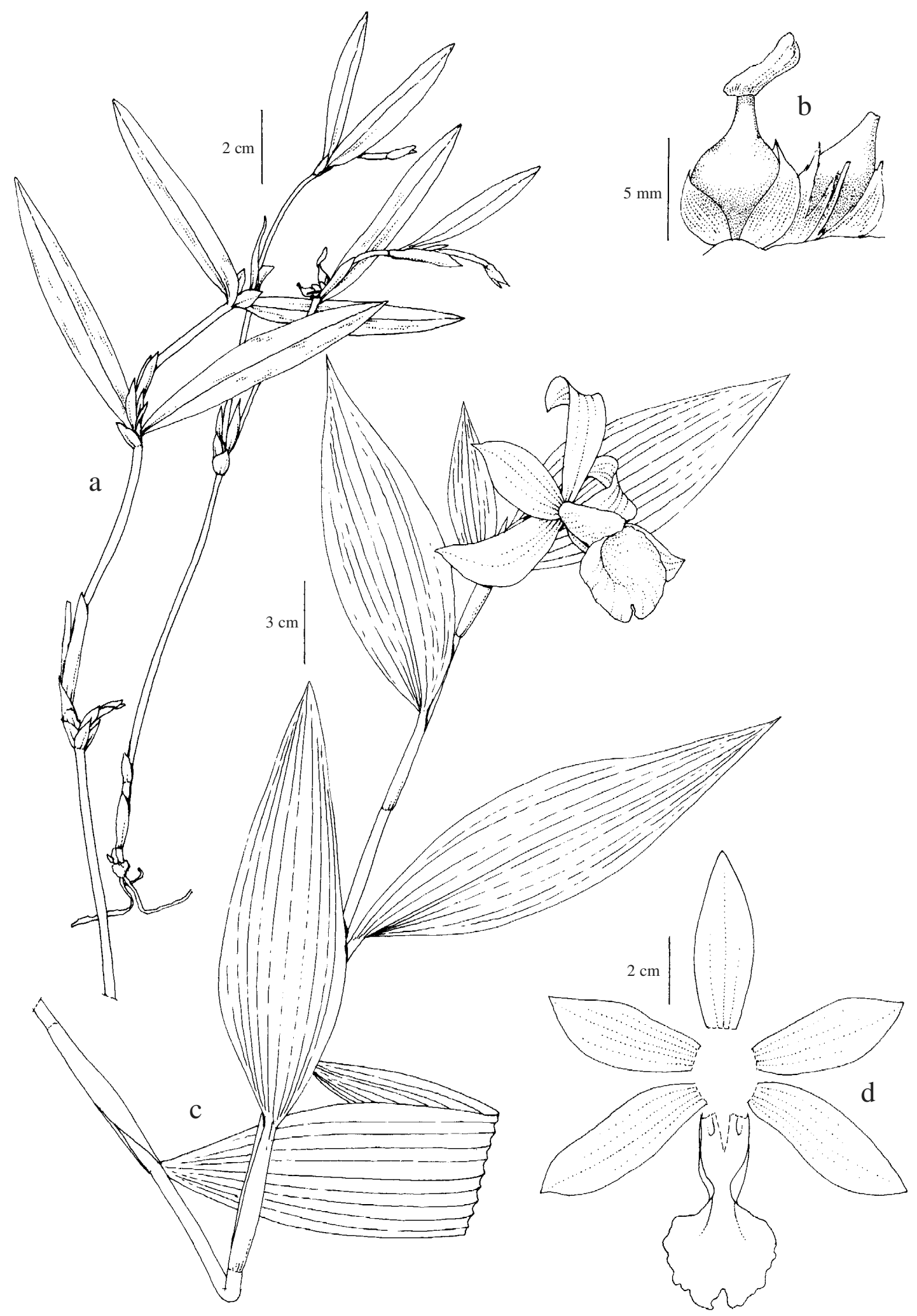

Figura 14a-b. Scaphyglottis modesta. a. Hábito. b. Fruto (C. Azevedo \& R. Oliveira 160). c-d. Sobralia sessilis. c. Hábito. d. Diagrama floral (C. Azevedo \& J. Oliveira 180). 
redescoberta por Anton de Ghillany na Serra do Sincorá (Toscano-de-Brito \& Robins 1992). Na Chapada Diamantina foi citada para Mucugê/ Andaraí (Harley \& Simmons 1986), Rio de Contas (Toscano-de-Brito 1995) e Catolés (Toscano-deBrito \& Queiroz 2003), identificada como Laelia bahiensis. Cresce diretamente sobre as rochas do campo rupestre a pleno sol, e floresce entre setembro e janeiro.

Sophronitis bahiensis é a única espécie do gênero com flores amarelas ocorrentes na Bahia. Apresenta grande variação na coloração não só das flores, como também vegetativamente, apresentando pseudobulbos e folhas que variam de verde a arroxeado, e flores de amarelo a laranja.

\section{Thelyschista Garay}

Thelyschista ghillanyi (Pabst) Garay, Bot. Mus. Leafl. 28(4): 377. 1982. Odontorrhynchus ghillanyi Pabst, Bradea 2: 166. 1977.

Figuras $15 \mathrm{c}-\mathrm{d}, 181-\mathrm{m}$

Erva terrestre. Rizoma inconspícuo, raízes engrossadas. Caule inconspícuo. Folhas 3-4 basais, em roseta, (5-)10-16 × 2,5-4,5 cm, sésseis, suberetas, oblongo-lanceoladas, verdes, membranáceas, ápice agudo. Inflorescência em racemo terminal, ereto; pedúnculo 17-40 cm compr., verde; brácteas do pedúnculo $30-35 \times 5-10 \mathrm{~mm}$, ovadas, membranáceas, ápice agudo; raque 13-22 cm compr., 10-23-flora; brácteas florais 20-23 × 7-8 mm, lanceoladas, membranáceas, ciliadas, ápice agudo, margem ciliada. Flores ressupinadas, pedicelo, incluindo o ovário, 14-15 mm compr.; sépalas verdes, membranáceas, ciliadas, a dorsal 18-20 × 4-5 mm, ereta, lanceolada, ápice obtuso, reflexo, as laterais 20-23 × 3-4 mm, patentes, lineares, ápice agudo, reflexo, margem involuta; pétalas 18-20 × 5-6 mm, eretas, lanceoladas, esbranquiçadas, membranáceas, ápice agudo, reflexo, margem serrilhada, aderente à sépala dorsal; labelo fixo ao pé da coluna, ereto, 3lobado, oblongo, esbranquiçado, membranáceo, lobos laterais $8,0-10 \times 2-3 \mathrm{~mm}$, envolvendo a coluna, coalescente na base à sua face lateral, semiorbiculares, ápice obtuso, lobo terminal 7-7,5 × 7-8 $\mathrm{mm}$, oblongo, ápice obtuso, reflexo, margem ondulada; coluna 6-7,5 × 3-3,5 mm, branca, base prolongada em pé de 3-4 mm compr., polínias 2 .
Materiais examinados: 27-XI-2002, C. Azevedo et al. 169 (HUEFS); 28-I-2003, C. Azevedo \& J. Oliveira 174 (HUEFS); Área da UMS, 25-I-2000, L.P. Queiroz 5681 (HUEFS); Unidade de Manejo Sustentável, 3-I-1997, UMS 67 (HRB); idem, 12-I-1997, UMS 187 (HRB).

Material adicional examinado: BRASIL. BAHIA: Mucugê, $2 \mathrm{~km}$ al N de Mucugê, 20-I-1997, M.M. Arbo et al. 7574 (CEPEC, CTES); idem, CFCR 411 (K, SPF); estrada Mucugê-Andaraí, 22-II-1994, CFCR 14405 (K, SPF); idem, 15-II-1974, Ghillány $001 / 74$ (K desenho do holótipo); about $3 \mathrm{~km} \mathrm{~N}$ of Mucugê, 5-II-1974, R.M. Harley et al. 15993 (CEPEC, K); ca. 3 km S of Mucugê, 4-II-1974, R.M. Harley et al. 15965 (CEPEC, K); a $3 \mathrm{~km}$ ao $\mathrm{S}$ de Mucugê, 22-XII-1979, S.A. Mori \& F.P. Benton 13172 (CEPEC).

Thelyschista ghillanyi foi originalmente descrita de espécime vindo da Chapada da Calabocaria, entre os municípios de Mucugê e Andaraí (Pabst 1977). Foi citada para a Serra do Sincorá por Harley \& Mayo (1980) e para Mucugê/Andaraí por Harley \& Simmons (1986), identificada como Odontorrhynchus ghillanyi. Thelyschista é um gênero monotípico, endêmico do Estado da Bahia. Através de estudos mais detalhados, Smidt (2003) confirmou o seu endemismo para a região central da Chapada Diamantina: Andaraí, Lençóis e Mucugê, e recentemente foi citada para Catolés (Toscano-deBrito \& Queiroz 2003). No Parque, Thelyschista ghillanyi cresce tanto em áreas mais fechadas de mata, como sobre a matéria orgânica que se acumula nas rochas do campo rupestre. Floresce entre novembro e fevereiro.

Esta espécie é facilmente reconhecida por suas grandes folhas dispostas em roseta, suas flores ressupinadas, verdes e seu labelo branco.

\section{Agradecimentos}

A todos do Parque Municipal de Mucugê: Oremildes Alves Oliveira, Euvaldo Ribeiro Júnior, Joaab Oliveira, Elaine, Ilza, Gilvan, Baúla, Nilton e Adriano Paraguassú por todo o apoio nas coletas, ajuda e atenção em minhas estadias no PMM. Ao Professor Eduardo Borba pelas sugestões e comentários críticos, e à Fundação de Amparo à Pesquisa da Bahia FAPESB pela bolsa de pesquisa. 


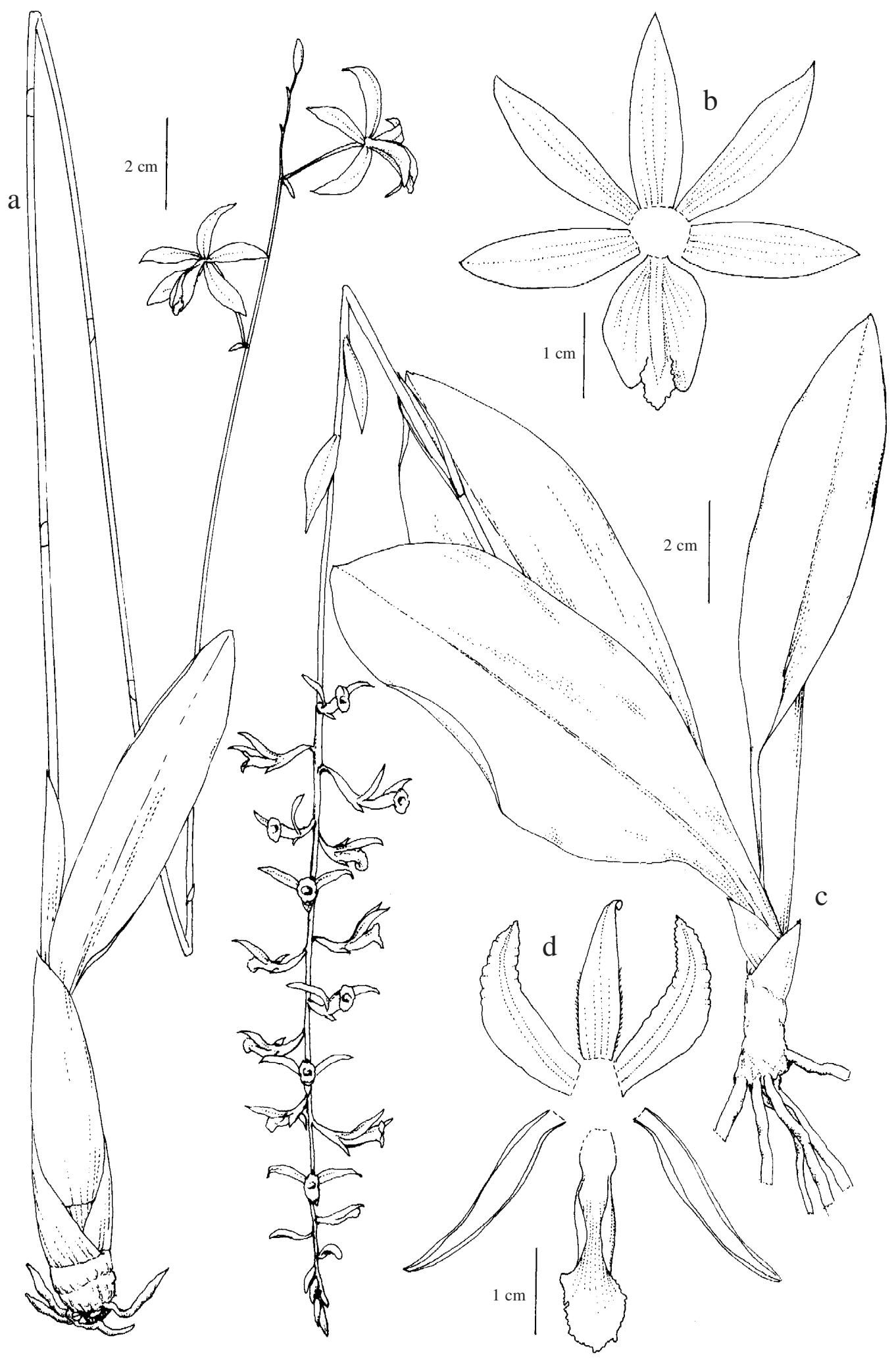

Figura 15a-b. Sophronitis bahiensis. a. Hábito. b. Diagrama floral (C. Azevedo \& E. Ribeiro 154). c-d. Thelyschista ghillanyi. c. Hábito. d. Diagrama floral (C. Azevedo \& J. Oliveira 174). 

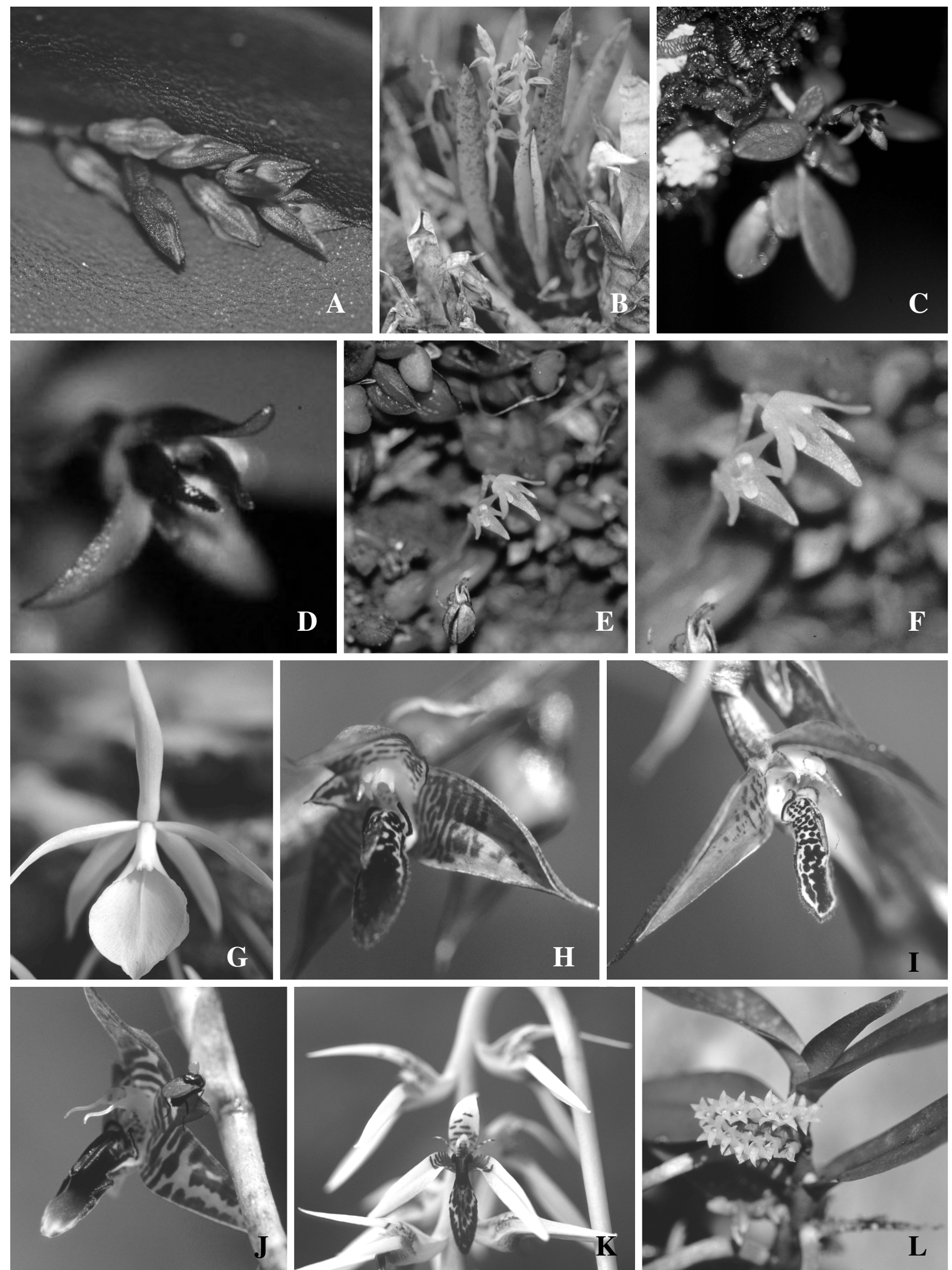

Figura16a. Acianthera hamosa. b. Acianthera ochreata subsp. ochreata. c-d . Anathallis microphyta. e-f. Anathallis montipelladensis. g. Brassavola tuberculata. h-i. Bulbophyllum $\times$ cipoense. j. Bulbophyllum involutum. k. Bulbophyllum weddellii. 1 . Campylocentrum micranthum. 

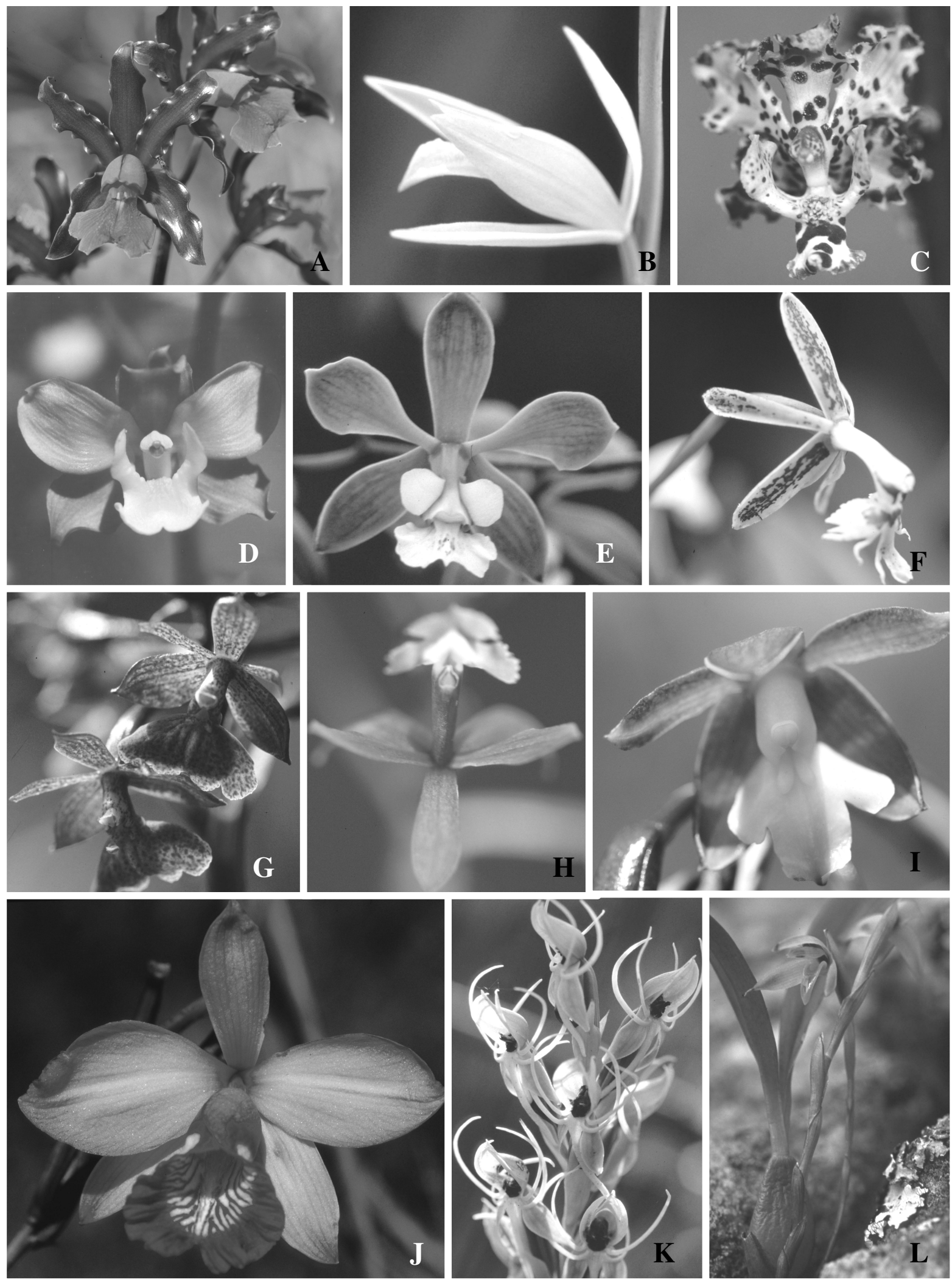

Figura 17a. Cattleya elongata. b. Cleistes exilis. c. Cyrtopodium aliciae. d. Cyrtopodium polyphyllum. e. Encyclia alboxanthina.f. Epidendrum cristatum. g. Epidendrum orchidiflorum. h. Epidendrum secundum. i. Epidendrum warasii. j. Epistephium lucidum. k. Habenaria fluminensis. 1. Maxillaria notylioglossa. 

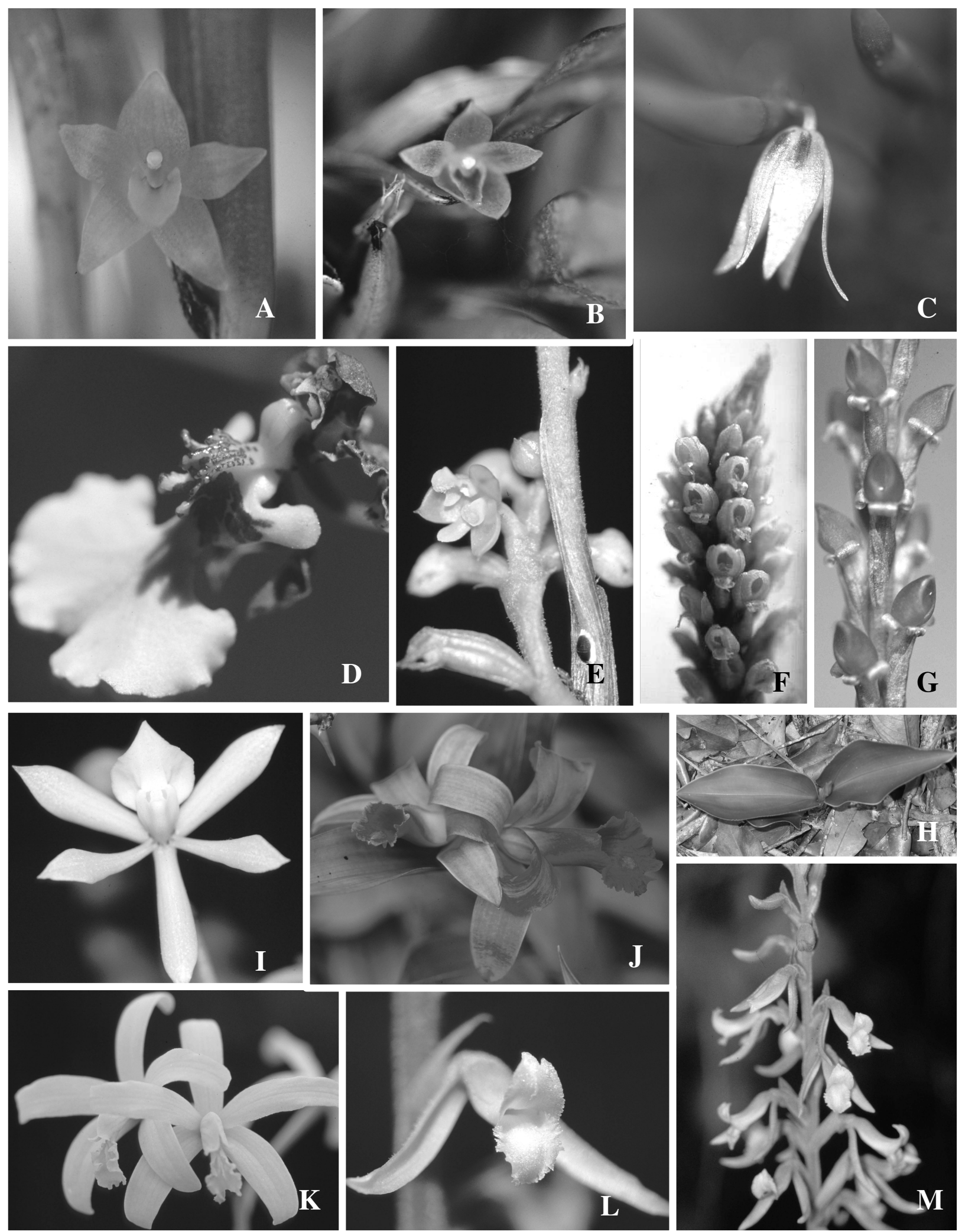

Figura 18a. Octomeria alexandrii. b. Octomeria sagittata. c. Octomeria flabellifera. d. Oncidium blanchetii. e. Polystachya micrantha. f. Prescottia montana. g-h. Prescottia stachyodes. i. Prosthechea moojenii. j. Sobralia sessilis. k. Sophronitis bahiensis. 1-m. Thelyschista ghillanyi. 


\section{Literatura citada}

Adams, B.R. 1993. A taxonomic revision of the genus Scaphyglottis Peoppig \& Endl. (OrchidaceaeEpidendroideae). Degree of Doctor of Philosophy. Southern Illinois University, Carbondale.

Atwood, J. 1986. The size of the Orchidaceae and the systematic distribution of epiphytic orchids. Selbyana 9: 171-186.

Azevedo, C.O. \& van den Berg, C. 2005. Anew combination in the genus Anathallis (Orchidaceae), and a new record for Bahia State, Brazil. Kew Bulletin 60: 137.

Azevedo, C.O., E.L.Borba \& van den Berg, C. 2006. Evidence of natural hybridization and introgression in Bulbophyllum involutum Borba, Semir \& F. Barros and B. weddellii (Lindl.) Rchb. f. (Orchidaceae) in the Chapada Diamantina, Brazil, by using allozyme markers. Revista Brasileira de Botânica 29: 415-421.

Barbosa-Rodrigues, J. 1877. Genera et species Orchidearum novarum I. C. \& H. Fleiuss, Rio de Janeiro.

Barbosa-Rodrigues, J. 1882. Genera et species Orchidearum novarum II. C. \& H. Fleiuss, Rio de Janeiro.

Barros, F. 1987. Orchidaceae. In: A.M. Giulietti, N.L. Menezes, J.R. Pirani, M. Meguro \& M.G.L. Wanderley (eds.). Flora da Serra do Cipó, Minas Gerais: caracterização e lista de espécies. Boletim de Botânica da Universidade de São Paulo 9: 1-151.

Barros, F. 1994. Novas combinações, novas ocorrências e notas sobre espécies pouco conhecidas, para as orquídeas do Brasil. Acta Botanica Brasilica 8: 11-17.

Barros, F. \& Pinheiro, F. 2004. Flora de Grão Mogol, Minas Gerais: Orchidaceae. Boletim de Botânica da Universidade de São Paulo 22: 361-383.

Batista, J.A.N. \& Bianchetti, L.B. 2002. A review of Habenaria (Orchidaceae) in Pabst and Dungs' Orchidaceae Brasilienses. Lindleyana 17: 75-84.

Bennett Junior, D.E. \& Christenson, E.A. 1993. Icones Orchidacearum Peruviarum. A. Pastorelli de Bennett, Lima.

Borba E.B. 2003. Novas combinações em Acianthera (Pleurothallis s. l.; Orchidaceae: Pleurothallidinae) ocorrentes nos campos rupestres brasileiros. Sitientibus, Série Ciências Biológicas 3: 22-25.

Borba, E.L. \& Semir, J. 1998. Bulbophyllum 'cipoense (Orchidaceae), a new natural hybrid from the Brazilian "campos rupestres": description and biology. Lindleyana 13: 113-120.

Borba, E.L. \& Semir, J. 2001. Pollinator specificity and convergence in fly-pollinated Pleurothallis (Orchidaceae) species: a multiple population approach. Annals of Botany 88: 75-88.

Borba, E.L., Felix, J.M., Semir, J. \& Solferini, V.N. 2000. Pleurothallis fabiobarrosii, a new Brazilian species: morphological and genetic data with notes on the taxonomy of Brazilian rupicolous Pleurothallis. Lindleyana 15: 2-9.
Borba, E.L., Semir, J. \& Barros, F. 1998. Bulbophyllum involutum Borba, Semir \& F.Barros (Orchidaceae), a new species from the Brazilian "campos rupestres". Novon 8: 225-229.

Borba, E.L, Shepherd, G.J., van den Berg, C. \& Semir, J. 2002. Floral and vegetative morphometrics of five Pleurothallis (Orchidaceae) species: correlation with taxonomy, phylogeny, genetic variability and pollination systems. Annals of Botany 90: 1-12.

Castro, V.P. \& Campacci, M.A. 2000. Icones Orchidacearum Brasiliensis I. Edição do autor, São Paulo.

Conceição, A.A. \& Giulietti, A.M. 2002. Composição florística e aspectos estruturais de campo rupestre em dois platôs do Morro do Pai Inácio, Chapada Diamantina, Bahia, Brasil. Hoehnea 29(1): 37-48.

Cribb, P. \& Toscano-de-Brito, A.L.V. 1996. Histórico. In: S. Sprunger; P. Cribb \& A.L.V. Toscano-de-Brito (eds.). Iconographie des Orchidées du Brèsil. v. 1. Reinhardt, Basle, pp. 42-47.

Cruz, D.T., Borba, E.L. \& van den Berg, C. 2003. O gênero Cattleya Lindl. (Orchidaceae) no Estado da Bahia, Brasil. Sitientibus Série Ciências Biológicas 3: 26-34.

Dressler, L.R. 1993. Phylogeny and classification of the orchid Family. Dioscorides Press, Portland.

Dressler, R.L. \& Whitten, W.M. (2004). Phylogenetic relationships of Scaphyglottis and related genera (Laeliinae: Orchidaceae) based on ITS sequence data. Brittonia 56: 58-66.

Dunsterville, G.C.K. \& Garay, L.A. 1959. Venezuelan Orchids Illustrated. vol. 1. Andre Deutsch Limited, London, 366 p.

Dunsterville, G.C.K. \& Garay, L.A. 1961. Venezuelan Orchids Illustrated. v. 2. Andre Deutsch Limited, London.

Fowlie, J.A. 1990. A new Encyclia species from Serra da Sincorá National Park, Bahia, Brazil; Encyclia alboxanthina Fowl., sp. nov. Orchid Digest 54: 25-28.

Giulietti, A.M., Menezes, N.L., Pirani, J.R., Meguro, M. \& Wanderley, M.GL. 1987. Flora da Serra do Cipó, Minas Gerais: caracterização e lista de espécies. Boletim de Botânica da Universidade de São Paulo 9: 1-151.

Guedes, M.L.S. \& Orge, M.D. (eds.) 1998. Checklist das espécies vasculares do Morro do Pai Inácio (Palmeiras) e Serra da Chapadinha (Lençóis), Chapada Diamantina, Bahia, Brasil. UFBA, Salvador.

Harley, R.M. 1995. Introdução. In: B.L. Stannard (ed.). Flora of the Pico das Almas: Chapada Diamantina, Bahia, Brazil. Royal Botanic Gardens, Kew, pp. 43-76.

Harley, R.M. \& Mayo, S.J. 1980. Towards a Checklist of the Flora of Bahia. Royal Botanic Gardens, London.

Harley, R.M. \& Simmons, N.A. 1986. Florula of Mucugê: Chapada Diamantina - Bahia, Brazil. Royal Botanic Gardens, London. 
Hoehne, F.C. 1930. Contribuições para o conhecimento da flora orchidologica brasílica II. Archivo do Instituto Biológico de Defesa Agrícola e Animal. Separado do v. 3: $287-320$.

Hoehne, F.C. 1936. Orchidaceae dos herbários de A.C.Brade e do Museu Nacional. Boletim do Museu Nacional de Rio de Janeiro 12: 1-20.

Hoehne, F.C. 1939. Orchidaceae. Arquivos de Botânica do Estado de São Paulo n.s. 1: 41.

Hoehne, F.C. 1940. Orchidaceae. In: F.C. Hoehne (ed.). Flora Brasilica. Secretaria da Agricultura, Indústria e Comércio de São Paulo, São Paulo, v. 12, parte 1, pp. 1-254.

Hoehne, F.C. 1942. Orchidaceae. In: F.C. Hoehne (ed.). Flora Brasilica. Secretaria da Agricultura, Indústria e Comércio de São Paulo, São Paulo, v. 12, parte 6, pp. 1-128.

Hoehne, F.C. 1945. Orchidaceae. In: F.C. Hoehne (ed.). Flora Brasilica. Secretaria da Agricultura, Indústria e Comércio de São Paulo, São Paulo, v. 12, parte 2, pp. 1-389.

Lindley, J. 1830. Pleurothallis prolífera. The Botanical Register; Consisting of Coloured Figures of Exotic Plants Cultivated in British Gardens; with their History and Mode of Treatment. London, v. 15.

Lindley, J. 1831. Genera and Species of Orchidaceous Plants, Part I. Ridgways, London.

Lindley, J. 1836a. Pleurothallis Gróbyi. The Botanical Register; Consisting of Coloured Figures of Exotic Plants Cultivated in British Gardens; with their History and Mode of Treatment. London, v. 21.

Lindley, J. 1836b. Prescóttia colórans. The Botanical Register; Consisting of Coloured Figures of Exotic Plants Cultivated in British Gardens; with their History and Mode of Treatment. London, v. 22.

Lindley, J. 1852. Didactyle. Folia Orchidacea. London.

Mori, S.A, Silva, L.A., Lisboa, G. \& Coradin, L. 1989. Manual de Manejo do Herbário Fanerogâmico. 2 ed. CEPLAC, Ilhéus.

Pabst, G.F.J. 1955. Um Epidendrum novo da Bahia. Orquídea (Rio de Janeiro) 17: 204-205.

Pabst, G.F.J. 1956. Additamenta ad Orchideologiam Brasiliensem - III. Orquídea (Rio de Janeiro) 18: 184-191.

Pabst, G.F.J. 1962. Notícias orquidológicas - VIII. Orquídea (Rio de Janeiro) 44-50.

Pabst, G.F.J. 1966. Additamenta ad Orchideologiam Brasiliensem - IX. Orquídea (Rio de Janeiro) 28: 164-168.

Pabst, G.F.J. 1971. Additamenta ad Orchideologiam Brasiliensem -XI. Bradea 1: 54-55.

Pabst, G.F.J. 1975. Additamenta ad Orchideologiam Brasiliensem - XX. Bradea 2: 49-56.

Pabst, G.F.J. 1977. Additamenta ad Orchideologiam Brasiliensem - XXIV. Bradea 2: 165-172.

Pabst, G.F.J. \& Dungs, F. 1975. Orchidaceae Brasilienses. v. 1. Kurt Schmersow, Hildesheim.
Pabst, G.F.J. \& Dungs, F. 1977. Orchidaceae Brasilienses. v. 2. Kurt Schmersow, Hildesheim.

Pirani, J.R., Mello-Silva, R. \& Giulietti,A.M. 2003. Flora de Grão-Mogol, Minas Gerais, Brasil. Boletim de Botânica da Universidade de São Paulo 21: 1-24.

Reichenbach, H.G. 1854. Die Wagener'schen Orchideen. Bonplandia 2: 9-26.

Rolfe, R.A. 1894. Barbosa Rodrigues's Brazilian Cattleyas. Orchid Review 2: 206-207.

Schlechter, R. 1920. Cyrtopodium paranaense. Repertorium Specierum Novarum Regni Vegetabilis 16: 333.

Schlechter, R. 1921. Orchidaceae Novae et Criticae. Repertorium Specierum Novarum Regni Vegetabilis 17: 272 .

Schlechter, R. 1922. Contribuições ao Conhecimento das Orquidáceas do Brasil. Memórias do Instituto Butantan, Sec. Bot. 1. 4: 50-54.

Silva, D.G. 2002. O gênero Cleistes Rich. ex Lindl. (Orchidaceae: Vanilloideae: Pogoniinae) na Chapada Diamantina, Bahia, Brasil. Dissertação de Mestrado, Universidade Estadual de Feira de Santana, Feira de Santana.

Smidt, E.C. 2003. A subtribo Spiranthinae Lindl. (Orchidaceae - Orchidoideae) na Chapada Diamantina, Bahia, Brasil. Dissertação de Mestrado, Universidade Estadual de Feira de Santana. Feira de Santana.

Sprunger, S. 1991. Catalogue. In: S. Sprunger; P. Cribb \& W.T. Stearn (eds.). Orchids from the Botanical Register 1815-1847. The illustrations. Birkhauser, Basel, pp. 219-322.

Sprunger, S., Cribb, P. \& Toscano-de-Brito, A.L.V. (eds.). 1996. Iconographie des Orchidées du Brèsil. v. 1. Reinhardt, Basle.

Stannard, B.L. (ed.). 1995. Flora of the Pico das Almas: Chapada Diamantina, Bahia, Brazil. Royal Botanic Gardens, London.

Stradmann, M.T.S. 1998. Plano de Manejo do Parque Municipal de Mucugê. Prefeitura Municipal de Mucugê. Projeto Sempre Viva/Convênio MMA/PNMA/PED 96 CV 00027/96. Mucugê.

Toscano-de-Brito, A.L.V. 1995. Orchidaceae. In: B.L. Stannard (ed.). Flora of the Pico das Almas: Chapada Diamantina, Bahia, Brazil. Royal Botanic Gardens, London, pp. 725-767.

Toscano-de-Brito, A.L.V. 1998. Orchidaceae. In: M.L.S. Guedes \& M.D. Orge (eds.). Checklist das Espécies Vasculares do Morro do Pai Inácio (Palmeiras) e Serra da Chapadinha (Lençóis), Chapada Diamantina, Bahia, Brasil. Universidade Federal da Bahia, Salvador, pp. 53-54. 
Toscano-de-Brito, A.L.V. \& Queiroz, L.P. 2003. Orchidaceae. In: D.C. Zappi, E. Lucas, B.L. Stannard, E.N. Lughadha, J.R. Pirani, L.P. Queiroz, S. Atkins, D.J.N. Hind, A.M. Giulietti, R.M. Harley \& A.M. Carvalho (eds.). Lista das plantas vasculares de Catolés, Chapada Diamantina, Bahia, Brasil. Boletim de Botânica da Universidade de São Paulo 21: 396-397.

Toscano-de-Brito, A.L.V. \& Robins, S. 1992. Laelia bahiensis. Kew Magazine 9: 116-120. van deb Berg, C. \& Azevedo, C.O. 2005. Orquídeas. In: F. Juncá, L.S. Funch, W. Rocha. Biodiversidade e Conservação da Chapada Diamantina. Ministério do Meio Ambiente, Brasília. pp.195-208.

Zappi, D.C, Lucas, E., Stannard, B.L., Lughadha, E.N., Pirani, J.R., Queiroz, L.P., Atkins, S., Hind, D.J.N., Giulietti, A.M., Harley, R.M. \& Carvalho, A.M. 2003. Lista das plantas vasculares de Catolés, Chapada Diamantina, Bahia, Brasil. Boletim de Botânica da Universidade de São Paulo 21: 345-398. 